\author{
UNIVERSIDADE DE SÃO PAULO \\ FACULDADE DE DIREITO DA USP \\ PROGRAMA DE PÓS-GRADUAÇÃO EM DIREITO
}

RICSON MOREIRA COELHO DA SILVA

\title{
A MUTABILIDADE DAS NORMAS CONSTITUCIONAIS E OS LIMITES DE ATUAÇÃO DO JUIZ
}




\section{RICSON MOREIRA COELHO DA SILVA}

\section{A MUTABILIDADE DAS NORMAS CONSTITUCIONAIS E OS LIMITES DE ATUAÇÃO DO JUIZ}

Dissertacão submetida à Universidade de São Paulo para obtenção do título de Mestre em Direito. Orientador: Professor Doutor Elival da Silva Ramos. 


\section{A MUTABILIDADE DAS NORMAS CONSTITUCIONAIS E OS LIMITES DE ATUAÇÃO DO JUIZ}

Esta dissertação foi julgada adequada para a obtenção do título de Mestre em Direito e aprovada em sua forma final pela Coordenação do Curso de Pós-Graduação em Direito da Universidade de São Paulo, na área de Direito do Estado.

Banca examinadora:

Presidente: Professor Doutor Elival da Silva Ramos

Membro FD: Professor (a) Doutor (a)

Membro estranho à FD:

Coordenador do Curso:

São Paulo 
Dedico este trabalho a minha esposa, Anna Wallérya, aos meus dois filhos, Vinícius e Guilherme, a minha mãe Lourdes e a meu tio, Carlos. 


\section{Agradecimentos}

Agradeço a todos que contribuíram, direta ou indiretamente, para a conclusão deste trabalho. Em especial, ao Professor Elival da Silva Ramos pela orientação e discussão dos temas aqui tratados.

Agradeço ainda à Universidade de São Paulo pelo alto nível do Programa de Pósgraduação oferecido, bem como à Procuradoria Geral da Fazenda Nacional, instituição que me concedeu licença para que pudesse concluir esta pesquisa. 
“Quanta verdade suporta e de quanta verdade é capaz um espírito".

Friedrich Nietzsche 


\section{RESUMO}

Este trabalho é uma análise crítica do tema da mutação constitucional. Buscouse a partir da revisitação de temas como o constitucionalismo e do conceito de Constituição, construir uma dogmática da mutabilidade das normas constitucionais e assim procedendo, verificar empiricamente, com base em precedentes da jurisprudência do Supremo Tribunal Federal, o acerto desta construção.

Uma vez estabelecidas as bases para a verificação do fenômeno da mutação constitucional, foi possível parametrizar os limites possíveis a esta hipótese de atualização das normas constitucionais.

Pois bem, nesses termos, fixado o conceito, verificado a sua aplicabilidade na jurisprudência, bem como estabelecidos os limites de sua utilização, foi possível ainda a partir da análise do contexto atual em que se insere o instituto, vislumbrar as hipóteses de sua aplicação futura.

Em suma, trata-se de um trabalho no qual se tenta compreender o papel da jurisdição constitucional com respeito ao tema de mutabilidade das normas constitucionais, sobretudo diante da realidade pós-moderna circundante, que pela sua complexidade, influencia, sensivelmente, a normatividade dos preceitos legais e, notadamente, dos constitucionais, objeto principal do estudo. 


\section{ABSTRACT}

This work is a critical analysis of the issue of constitutional change. We sought from revisiting issues such as constitutionalism and the concept of constitution building a dogmatic mutability of constitutional norms and in so doing, to verify empirically, based on the precedents jurisprudence of the Supreme Court, the correctness of this construction.

Once established the basis for the verification of the phenomenon of constitutional change, it was possible to parameterize the possible limits to this hypothesis update of constitutional norms .

Well, in these terms, the concept set, verifying their applicability in case law as well as established the limits of their use, it was still possible from the analysis of the current context in which it appears the institute, envision the chances of its future application.

In short, it is a work in which one tries to understand the role of constitutional jurisdiction with respect to the theme of mutability of constitutional norms, particularly in the surrounding postmodern reality, which by their complexity, significantly influences the normativity of legal precepts and especially, constitutional, the main object of study. 
A aprovação da presente dissertação não significará o endosso do Professor Orientador, da Banca Examinadora e da Universidade de São Paulo à ideologia que fundamenta ou que nela é exposta. 
LISTA DE ABREVIATURAS

ADI - AÇAO DIRETA DE INCONSTITUCIONALIDADE

ADPF - ARGUIÇÃO DE DESCUMPRIMENTO DE PRECEITO FUNDAMENTAL

AGU - ADVOCACIA GERAL DA UNIÃO

DPU - DEFENSORIA PÚBLICA DA UNIÃO

RE - RECURSO EXTRAORDINÁRIO

STF - SUPREMO TRIBUNAL FEDERAL

TSE - SUPREMO TRIBUNAL FEDERAL 
SUMÁRIO

INTRODUÇÃO ..........................................................................................................................12

CAPÍTULO I - A CONSTITUIÇÃO E SUA MUTAÇÃO 17

1.1 Do movimento constitucionalista no mundo e no Brasil ............................................17

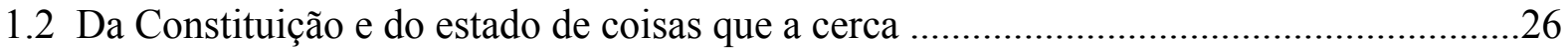

1.3 Da mutação constitucional e das suas modalidades de verificação ..................................32

1.4 Mutação constitucional a partir da desconexão entre realidade e norma ..........................36

1.5 Mutação constitucional a partir da interpretação inovadora e integradora .......................39

1.6 A mutação constitucional a partir da obsolescência da norma constitucional ...................45

1.7 A mutação constitucional a partir da alteração inconstitucional da normatividade de um preceito

\section{CAPÍtULO II - MUTAÇÃO CONSTITUCIONAL E OS PRECEDENTES DO

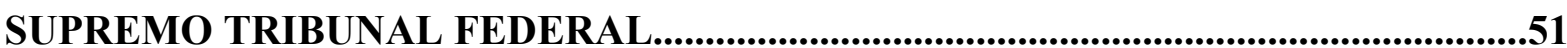

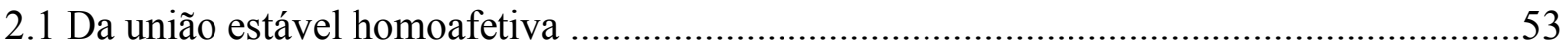

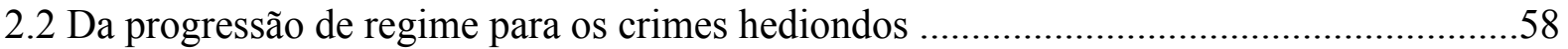

2.3 Suspensão de ato considerado inconstitucional pelo STF mediante ato do Senado Federal (Art. 52, $\mathrm{X}$ da CF)

2.4 Da prisão civil por dívida .65

2.5 Defesa da constitucionalidade do ato pelo Advogado Geral da União 67

\section{CAPÍTULO III - MUTAÇÃO CONSTITUCIONAL E LIMITES POSSÍVEIS: POSTULADOS DEMOCRÁTICOS, TEXTO NORMATIVO E JURISPRUDÊNCIA..70}

3.1 Mutação Constitucional e o déficit democrático .73

3.2 Texto normativo como ponto de partida e referencial último das mutações constitucionais

3.3. Do papel e importância da Jurisprudência no contexto da mutação constitucional 85 
CAPÍtUlo IV - MUTAÇÃO CONSTITUCIONAL, PANORAMAS DE

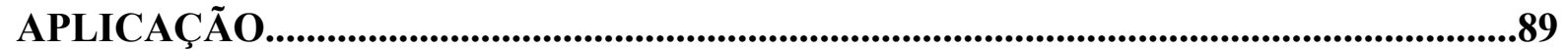

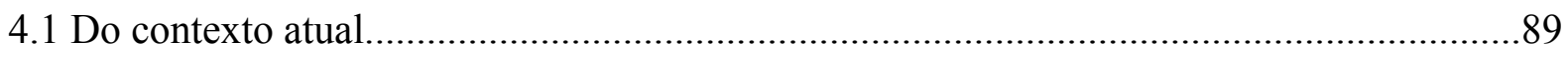

4.2 Panorama das mutações constitucionais no Brasil..........................................................95

CONCLUSÃO

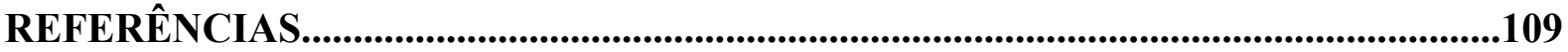




\section{INTRODUÇÃO}

A desconfiança mútua no que concerne ao agir das pessoas e quanto à delimitação de espaço do Estado, própria do Ocidente e traço do liberalismo político ${ }^{1}$, fez-se controlável e foi disciplinada idealmente por algo que tomou, em certo aspecto, um caráter contratual, suficientemente capaz de a um só tempo, mediante uma linguagem a todos compreensível, reduzir artificialmente essa complexa relação e estabelecer um modelo possível de separação, cooperação e intercâmbio entre Estado, sociedade e indivíduos.

Nesse contexto, o direito e, notadamente, a Constituição assumem importância fulcral. Não só por transformar e qualificar indivíduos como cidadãos, conferindo-lhes direitos e deveres na organização social, política e econômica, como também por conformá-la, sob a tutela de um ideal e suposto contrato social baseado na liberdade e na igualdade das pessoas $^{2}$.

Deste modo, ao estruturar uma espécie de regramento central de condutas ${ }^{3}$, o direito e a Constituição, mediante uma generalização de expectativas normativas e através de um código por todos compartilhado, influenciam o comportamento das pessoas e direcionam as atividades e objetivos das instituições.

Esse código e essa linguagem ${ }^{4}$ são os veículos de imposição das regras e princípios jurídicos escritos ${ }^{5}$ do qual se vale a Constituição a fim de estruturar um modelo social, político e econômico específico de cada Estado, bem como para exercer uma eficácia

\footnotetext{
${ }^{1}$ Cf. RAWLS, John. O Liberalismo Político. Álvaro de Vita (Trad.). São Paulo: WMF Martins Fontes, 2011.

${ }^{2}$ Cf. ROSSEAU, Jean-Jacques. Do Contrato Social. Tradução de Pietro Nassetti. São Paulo: Martin Claret, 2002.

${ }^{3}$ Cf. KELSEN, Hans. Teoria Pura do Direito. $6^{\text {a }}$ edição. João Baptista Machado (Trad.). Coimbra: Armínio Amado, 2003. p. 21. BOBBIO, Noberto. O Positivismo Jurídico: Lições de filosofia do Direito. Márcio Pugliesi; Edson Bonie; Carlos E. Rodrigues (Trads). São Paulo: Ícone, 1995. p. 27-8.

${ }^{4}$ Cf. ADEODATO, João Maurício. Filosofia do Direito: uma crítica à verdade na ética e na ciência. São Paulo: Saraiva, 2002. p. 217.

${ }^{5}$ Para o deslinde do presente trabalho, reduziu-se a análise sobre Constituições escritas, posto que não faz sentido, como se verá à frente, cogitar de mutação constitucional quanto a Constituições históricas, não-escritas.
} 
mínima da qual não pode prescindir. Com efeito, haja vista o ímpeto de ajustar a sociedade ao seu escopo, que nada mais é do que o desejo da própria comunidade política que se vê executado na ordem vigente ou que se pretende realizar.

Em decorrência, a Constituição como direito e documento jurídico de característica superior exerce uma supremacia que lhe garante normatividade, a ponto de assegurar o alinhamento da legislação vindoura e dos costumes sociais, políticos, econômicos e culturais a seus ditames. É dizer, vincula não só os próprios súditos que a ela "aderiram", como as gerações futuras, influenciando decisivamente a realidade circundante, à medida que se torna compreensível e respeitada por todos.

Acontece que esse modelo de Constituição escrita e rígida, referenciada a um texto posto e, a princípio estanque, não se sustenta sem que haja um permanente diálogo interpretativo com a evolução dos costumes sociais e das práticas econômicas, políticas e culturais, os quais representam uma espécie de metabolismo social ${ }^{6}$. Deveras, pois, do contrário, essa superestrutura normativa seria totalmente corroída pela simples passagem do tempo.

Nota-se, contudo, que essa conversa entre texto e realidade pode se mostrar tensa, pois a Constituição ao se prestar ao desenvolvimento e estabelecimento de um modelo determinado e ao descarte, por consequência, de outros caminhos possíveis, tende a ignorar a possibilidade de que diversas circunstâncias se sobreponham neste processo, com força suficiente para criar práticas capazes, inclusive de ruir, ainda que parcialmente, o projeto inicial sacralizado no código referido.

Diante de tal conjuntura, não só a realidade tem-se imposto perante os programas normativos, superando-os, como também o Poder Judiciário tem preenchido esse papel de atualizador das normas e de criador de certos conteúdos normativos inéditos. Isto é, ao intérprete, por natureza, tem se destacado a função de criador legislativo ${ }^{7}$, numa medida

\footnotetext{
${ }^{6}$ CANOTILHO, José Joaquim Gomes. Direito Constitucional. 6 a ed. Coimbra: Livraria Almedina, 1993. p. 79.

${ }^{7}$ Como hipótese representativa dessa qualificação, destaque-se que em 2008, o então presidente do Congresso Nacional, o Senador Garibaldi Alves, fez referência a este tema, conforme relato jornalístico a seguir: "durante o discurso de abertura dos trabalhos legislativos do Congresso Nacional nesta quarta-feira (6), o presidente do Senado, Garibaldi Alves Filho (PMDB), criticou, entre outros pontos, a atitude do Poder Judiciário em legislar pelo parlamento. Para o senador potiguar, a invasão de competência é perigosa para a democracia. Abrindo suas
} 
que supera a reserva criativa do próprio procedimento interpretativo, estruturando evidentemente uma nova relação entre expectativas comportamentais normativas e a realidade subjacente, no qual há o privilégio desta segunda circunstância.

Demais disso, essa atualização do texto constitucional pode dá início, em caso de superdimensionamento do papel do Poder Judiciário, a um rompimento da fronteira de legitimidade dos precedentes jurisprudenciais. Tal conduta, à medida que importe modificação relevante do preceito normativo, é capaz de tornar letra morta, carente de concretização a vontade do Poder Constituinte, seja originário ou derivado. Isto faz com que o intérprete, sobretudo aquele não judicial não mais se reconheça nas proposições normativas, que foram resultado de uma atividade constituinte, assente na representação política do povo, sob uma alma de índole contratual e posta em um código dotado de significação limitada.

Sendo assim, tudo isso acaba atraindo, pois, a necessidade de algumas adequações, tanto do alcance do texto e da ideia de Constituição, da sua normatividade, como do papel das instituições quanto a sua guarda, notadamente do Poder Judiciário.

Nesse viés, a discussão do presente trabalho consiste em investigar sob que medida essa Constituição, retrato de uma vontade social específica, posta sob um código restrito, seria afetada ou sucumbiria, diante de decisões de uma corte, com funções constitucionais, que "adequa" seu conteúdo a mudanças originadas a partir do desenvolvimento de novos comportamentos sociais e substitui preceitos constitucionais por normas que ao fim e ao cabo não guardam qualquer proximidade com o sentido semântico do texto ou de suas possibilidades normativas.

\footnotetext{
demoradas palavras admitindo que o 'Congresso está muito aquém do momento de nacionalidade que o país vive', Garibaldi relatou a dificuldade que os parlamentares enfrentam para legislar. (...) Outro ponto considerado nocivo ao trabalho legislativo por Garibaldi é a interferência dos poderes Executivo e Judiciário na atividade legislativa. As medidas provisórias, além das próprias resoluções dos tribunais superiores, são fatores que contribuem para o enfraquecimento e desprestígio do Congresso Nacional. 'Quando cada medida provisória editada sem a urgência necessária é apresentada, a Constituição é rasgada com desprezo. Já quando o Judiciário está legislando é um fato perigoso para a democracia', analisou Garibaldi. Mesmo criticando, o presidente do Senado admitiu que a participação do Judiciário em assuntos de competência do Congresso ocorre quando há a omissão do Poder Legislativo, e as ações dos tribunais superiores vêm recebendo avaliação positiva por parte da opinião pública. No entanto, Garibaldi pretende trabalhar para que o Legislativo cumpra o seu papel. 'Quando o Judiciário está legislando, está se transferindo um debate para o campo jurídico que deveria ser um debate político', disse, conforme trecho de reportagem publicada no sítio, http://www.nominuto.com/noticias/politica/garibaldi-critica-invasao-de-competencia-do-poder-judiciario/11639/ acesso em 22 de agosto de 2010.
} 
Em outras palavras, busca-se estabelecer sob que pressupostos a atualização das normas constitucionais pelo Poder Judiciário pode conviver com a regra da representatividade, que fora alçada a postulado máximo da democracia, já que o fato de um Poder, precipuamente guardião da Constituição, passar a ser modificador último de seu conteúdo, ou seja, o fato do guarda passar a ser senhor do objeto protegido, podendo-lhe conferir a forma que lhe melhor dispuser, é situação que contribui para um ambiente de grande incerteza jurídica.

Pois bem, percebe-se que o instituto da mutação constitucional nos mostra um exemplo típico do quanto discutido. É que como procedimento de mudança informal da Constituição, leia-se, meio de atualização do texto normativo, pode se desenhar retoricamente a partir de tal instituto jurídico uma espécie de anteparo a decisões que buscam modificar, por motivos obscuros e até inconscientes, a semântica natural do texto. E, em algum aspecto, trazer à baila um certo decisionismo, de início, pernicioso ao modelo democrático e aos cânones da segurança jurídica, pois significará anulação da Constituição posta.

Nesses termos, interessa-se, diante de tal concepção, investigar em que medida a atuação judicial ao reconhecer ou fomentar o processo de mutação pode caminhar em um sentido contrário à concretização normativa, valendo-se da interpretação constitucional para sepultar determinadas consequências que os magistrados repelem por razões não tão claras e democráticas, mas que foram assim desejadas pelo legislador, contudo. E, interessa-se também pelas consequências deste estado de coisas, na qual ocorre a instauração de uma circunstância de plena ineficácia normativo-jurídica do texto constitucional e de suas possibilidades normativas.

Assim, o desenvolvimento do presente trabalho pretende circunscrever-se ao tema da mutação constitucional e sua relação com o ativismo judicial e o processo democrático, no qual as decisões do Supremo Tribunal Federal serão de grande valia na compreensão deste fenômeno. E ainda, uma vez instaurado tal fenômeno, quais os caminhos seguros que as decisões podem caminhar, sem que ao assim agirem, estejam os juízes usurpando competência que não lhes fora conferida.

Daí a importância do tema proposto, pois a partir dos elementos mencionados, sobretudo, da análise jurisprudencial, poder-se-á contribuir para a definição acerca de quais 
instituições estamos a construir e em que medida tais configurações influenciam no grau de democracia que vivenciamos e passaremos a conviver, conforme adiante estudado.

Para tanto, em arremate, dividiu-se o trabalho em duas partes. Na primeira, tratar-se-á da Constituição e de suas possibilidades de mudança e, na segunda parte, os limites e prognósticos dominarão seu conteúdo. 


\section{CAPÍTULO I - A CONSTITUIÇÃO E SUA MUTAÇÃo}

Para bem compreender o objeto de nosso trabalho é necessário, nesta primeira parte, pontuar o que se entende por Constituição e seu atual estado de evolução, razão pela qual desenvolvemos o tópico seguinte como instrumento de compreensão do instituto, desde seus primórdios até os dias de hoje, acrescendo uma breve análise particularizada da experiência brasileira.

Pois bem, uma vez definida e situada ontologicamente ${ }^{8}$, poderemos avançar e discutir, conforme item sucessivo, qual o alcance de uma mutação constitucional e como ela se manifesta na estrutura vigente.

Sendo assim, passa-se a análise do primeiro tema relevante para o desenvolvimento do presente trabalho, qual seja, constitucionalismo e Constituição.

\subsection{Do movimento constitucionalista no mundo e no Brasil}

As sociedades, os agregados humanos, sejam primitivos, sejam modernos, sempre necessitaram de um código normativo a reger suas relações, ao passo que também não

\footnotetext{
${ }^{8}$ Sobre o problema da ontologia jurídica, alerta João Maurício Adeodato que a mesma "desdobra-se em uma série de questões interligadas que podem ser didaticamente distinguidas: 1) investigar se se pode falar de um fenômeno social específico a que corresponderia a denominação 'direito', se o direito se separaria de outras ordens normativas e contextos lingüísticos a ele assemelhados; 2) examinar se sob essa denominação, existe um fenômeno permanente que, apesar de suas variações no tempo e no espaço, guarda características comuns e generalizadas, as quais podem ser ditas sempre presentes; 3) Em terceiro lugar, partindo do princípio de que se responda afirmativamente à primeira questão, observar se esses caracteres ônticos podem ser apreendidos pelo sujeito cognoscente dentro de uma ontologia, fornecendo assim as bases sobre que se poderia procurar construir de conhecimento científico verdadeiro; 4) Verificar se esses caracteres ônticos são meramente formais, como coercitividade, ou se precisam apresentar um conteúdo ético mais ou menos definido para que se possa determinar o fenômeno observado como jurídico; 5) Em uma aporia já logicamente posterior, tentar determinar quais os critérios para separar o jurídico de fenômenos sociais e contextos lingüísticos outros que aparentemente se lhe assemelham. 6) Depois, uma vez situado o direito, apontar os critérios de separação entre lícito e ilícito, por exemplo, se dependem ou não do pacto político, do Estado, da 'razão' etc. A atitude gnoseológica das ontologias jurídicas responde afirmativamente a essas questões. (ADEODATO, João Maurício. Filosofia do Direito: uma crítica à verdade na ética e na ciência. São Paulo: Saraiva, 2002. p. 223-224).
} 
puderam abdicar de uma relação de $\operatorname{poder}^{9}$ que pudesse reunir e manter coesa aqueles "aglomerados". Esse código normativo poderia ser escrito ou mesmo costumeiro e deveria está internalizado perante seus membros. Já em caso de sua não observância, teria de haver algo com força suficiente a fazer respeitar o código, ainda que uma força estritamente moral e não física propriamente dita ${ }^{10}$.

Com o crescimento populacional, com a intensificação das trocas comerciais, com o desenvolvimento dos meios de transporte, de comunicação e a consequente aproximação dos povos, essas particulares relações de poder, normativas e sociais, ganharam um novo contorno, tornando-se mais complexas e amplas.

Essa complexidade das relações de poder e comportamento dos membros de uma sociedade, de uma comunidade, seja no ambiente interno, seja perante os outros povos, foi acompanhada pelo advento de uma nova era histórica do desenvolvimento humano, que se deu em muitas áreas, inclusive no universo político-jurídico.

Estamos falando de um momento que se fez presente durante um período de consolidação do processo civilizatório, localizado na Europa, durante a Idade Média. Nesta era, formaram-se reinos que tiveram sua autoridade posta em xeque por setores de sua respectiva nobreza, ligados à religião, além de uma ascedente burguesia, ainda incipiente, decerto, mas que reinvidicavam para si uma maior participação política nas decisões ou, ao menos, uma menor interferência dos reis em suas atividades privadas.

É um momento de afirmação do indivíduo e delimitação e estabelecimento do papel do Estado ${ }^{11}$, à época, decodificado na estrutura dos reinados e personificado pelo absolutismo dos reis europeus.

\footnotetext{
${ }^{9}$ As relações de poder, pontua-se, "são resultado do conjunto das relações de força", como bem destacou Gilles Delleuze Foucault apud CAPELLER, Nanda de Lemos. Fênix e o eterno retorno: a dialética entre a imaginação sociológica e a força do Estado. Lições de Direito Alternativo 2. p. 71.

${ }^{10}$ Sobre a relação entre coercibilidade e coatividade, veja-se FERRAZ JÚNIOR, Tércio Sampaio. Introdução ao Estudo do Direito: técnica, decisão, dominação. 4a ed. São Paulo: Atlas, 2003. p. 121.

${ }^{11}$ Segundo Azambuja, O Estado "é uma sociedade, pois se constitui essencialmente de um grupo de indivíduos unidos e organizados permanentemente para realizar um objetivo comum. E se denomina sociedade política, porque, tendo sua organização determinada por normas de Direito positivo, é hierarquizada na forma de governantes e governados e tem uma finalidade própria, o bem público (...) O Estado aparece, assim, aos indivíduos e sociedades como um poder de mando, como governo e dominação. $\mathrm{O}$ aspecto coativo e a
} 
Nesse contexto, é que surge o movimento pertinente à constitucionalização ${ }^{12}$ das sociedades políticas, encontrando em um documento denominado de Constituição os valores então perseguidos, pertinentes à garantia dos direitos fundamentais e à limitação do poder estatal.

Pois bem, é na Magna Carta de $1215^{13}$ e 14 , outorgada pelo então rei inglês, João Sem Terra, há cerca de oitocentos anos, que encontraremos o primeiro embrião que traduziu todo esse movimento. Na Magna Carta, que ainda não podemos chamá-la de Constituição, o rei cedeu parcela de seu poder absoluto a fim de conferir direitos à determinada parcela da sociedade, em um contexto político que lhe propiciou a manutenção do seu poder, ainda que mitigado. A situação, leia-se: os desmandos reais haviam chegado a um ponto crítico, e temas como liberdade religiosa, de propriedade e tributação, tornaram-se as grandes bandeiras deste movimento de limitação do poder real.

generalidade é o que distingue as normas por ele editadas; suas decisões obrigam a todos os que habitam seu território. (AZAMBUJA, Darcy. Teoria Geral do Estado. 27 a ed. Rio de Janeiro: Globo, 1988. p. 2 e 5).

12 “O movimento constitucional gerador da Constituição, em sentido moderno, tem várias raízes localizadas em horizontes temporais diacrônicos e em espaços históricos geográficos e culturais diferenciados. Em termos rigorosos, não há um constitucionalismo, mas vários constitucionalismos (o constitucionalismo inglês, o constitucionalismo americano, o constitucionalismo francês. Será preferível dizer que existem diversos movimentos constitucionais com corações nacionais, mas também com alguns momentos de aproximação entre si, fornecendo uma completa tessitura histórico-cultural. E dizemos ser mais rigoroso falar de vários movimentos constitucionais do que de vários constitucionalismos porque isso permite recortar desde já uma noção básica de constitucionalismo. Constitucionalismo é a teoria (ou ideologia) que ergue o princípio do governo limitado indispensável à garantia dos direitos em dimensão estruturante da organização político-social de uma comunidade. Nesse sentido, o constitucionalismo moderno representará uma técnica específica de limitação do poder com fins garantísticos. O conceito de constitucionalismo transporta, assim, um claro juízo de valor. E, no fundo, uma teoria normativa da política, tal como a teoria da democracia ou a teoria do liberalismo."

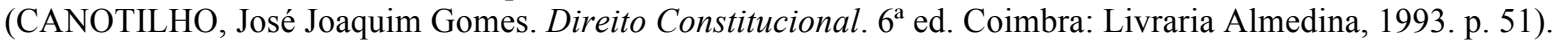

\footnotetext{
${ }^{13}$ Como bem pontua Fábio Konder Comparato, "toda a Alta Idade Média foi marcada pelo esfacelamento do poder político e econômico, com a instauração do feudalismo. A partir do século XI, porém, assiste-se a um movimento de reconstrução da unidade política perdida. Duas cabeças reinantes, o imperador carolíngio e o papa, passaram a disputar asperamente a hegemonia suprema sobre todo o território europeu. Ao mesmo tempo, os reis até então considerados nobres de condição mais elevada que os outros, reivindicaram para as suas coroas poderes e prerrogativas que até então, pertenciam de direito à nobreza e ao clero. Foi justamente contra os abusos dessa reconcentração do poder que surgiram as primeiras manifestações de rebeldia: na península ibérica com a Declaração das Cortes de Leão de 1188 e, sobretudo, na Inglaterra com a Magna Carta de 1215." (COMPARATO, Fábio Konder. A Afirmação Histórica dos Direitos Humanos. $7^{a}$ ed. São Paulo: Saraiva, 2010. p. 57-8).

${ }^{14}$ Cf. BARROSO, Luís Roberto. Curso de Direito Constitucional Contemporâneo: os conceitos fundamentais e a construção do novo modelo. São Paulo: Saraiva, 2009. p. 10.
} 
É bem verdade que a Magna Carta, assim como o Habeas Corpus Act e a Bill of Rights ${ }^{15}$, todos documentos de origem inglesa, ideologicamente contínuos, representam não propriamente uma espécie do que chamamos hoje de Constituição. Tais documentos importam em pactos de poder, que se "desenvolveram no âmbito dos conflitos de interesses dos barões feudais e da burguesia emergente contra o monarca do Estado absoluto."16 Tais pactos não devem ser confundidos com a Constituição em sentido moderno, reitere-se ${ }^{17}$.

É que, seja na perspectiva sociológica, ou mesmo na linguagem jurídica, os pactos eram particulares, "individualizados", compondo acordos entre o monarca, a nobreza e parte da burguesia, apenas. Enquanto que a Constituição, em sentido moderno, possui a pretensão de universalidade.

Em outras palavras, pode-se afirmar que os pactos de poder implicam uma linguagem particularista e excludente no nível pragmático dos que estão facultados a empregá-la e dos que são seus destinatários, enquanto a Constituição moderna pretende ser uma linguagem pragmaticamente universalista ${ }^{18}$.

Já superada a Idade Média, dois documentos aprovados, em momentos muito próximos, consolidaram este movimento constitucionalista ${ }^{19}$, quais sejam, a declaração de

\footnotetext{
15 "As liberdades pessoais que se procuraram garantir pelo habeas corpus e o bill of rights do final do século, não beneficiavam indistintamente todos os súditos de Sua Majestade, mas, preferencialmente, os dois primeiros estamentos do reino: o clero e a nobreza. A novidade é que, pela sua formulação mais geral e abstrata do que o texto da Magna Carta, garantia dessas liberdades individuais acabou aproveitando, e muito, à burguesia rica. Pode-se mesmo afirmar que, sem esse novo estatuto das liberdades civis e políticas, o capitalismo industrial dos séculos seguintes, dificilmente teria prosperado. A instituição-chave para a limitação do poder monárquico e a garantia das liberdades na sociedade civil foi o Parlamento. A partir do Bill of Rights britânico, a ideia de um governo representativo, ainda que não de todo o povo, mas pelo menos de suas camadas superiores, começa a firmar-se como uma garantia indispensável das liberdades civis." (COMPARATO, Fábio Konder. A Afirmação Histórica dos Direitos Humanos. $7^{\mathrm{a}}$ ed. São Paulo: Saraiva, 2010. p. 61-2).
}

${ }^{16}$ Cf. NEVES, Marcelo. Transconstitucionalismo. São Paulo: WMF Martins Fontes, 2009. p. 19.

17 "De fato, os pactos de poder ou leis fundamentais na Inglaterra [Magna Carta, Habeas Corpus Act, Bill of Rights] (...) apontavam para um desenvolvimento funcionalmente equivalente ao que conduziu às Constituições revolucionárias nos Estados Unidos e na França, mas não eram, isoladamente, expressões semânticas do constitucionalismo, tendo sido antes elementos de um processo evolutivo de diferenciação entre direito e política, o qual resultou em um constitucionalismo atípico nos séculos XIX e XX". (NEVES, Marcelo. Idem. p. 23).

${ }^{18}$ Cf. ibdem. p. 20.

19 “Constitucionalismo significa, em essência, limitação do poder e supremacia da lei [Estado de direito, rule of law, Rechtsstaat]. O nome sugere, de modo explícito, a existência de uma Constituição, mas a associação nem sempre é necessária e verdadeira. Há pelo menos um caso notório em que o ideal constitucionalista está presente 
direito do povo da Virgínia, 1776, nos Estados Unidos da América ${ }^{20}{ }^{21}$ e a Declaração de Direitos do Homem, 1789, na França ${ }^{22 \mathrm{e} 23 \mathrm{e} 24}$. Esses dois documentos passaram para história como modelos, agregando um caráter universalista aos movimentos constitucionais do mundo ocidental (sentimento até então inexistente em terras inglesas), fazendo surgir na teoria constitucional uma tríade de paradigmas do constitucionalismo ${ }^{25}{ }_{-}^{26}$ (historicista, individualista e estadualista), como bem anota J. J. Gomes Canotilho ${ }^{27}$ :

independentemente de Constituição escrita - o do Reino Unido - e outros, muito mais numerosos, em que ele passa longe, apesar da vigência formal e solene de Cartas escritas. Exemplo inequívoco é o fornecido pelas múltiplas ditaduras latino-americanas dos últimos quarenta anos. Não basta, portanto, a existência de uma ordem jurídica qualquer. É preciso que ela seja dotada de determinados atributos e que tenha legitimidade, a adesão voluntária e espontânea de seus destinatários".(BARROSO, Luís Roberto. Curso de Direito Constitucional Contemporâneo: os conceitos fundamentais e a construção do novo modelo. São Paulo: Saraiva, 2009. p. 5).

20 “Em 17 de setembro de 1787 o texto foi aprovado pela Convenção e estava pronto para ser submetido à ratificação dos Estados. A primeira Constituição escrita do mundo moderno passou a ser o marco simbólico da conclusão da Revolução Americana em seu tríplice conteúdo: a] independência das colônias; b] superação do modelo monárquico; c] implantação de um governo constitucional, fundado na separação de Poderes, na igualdade e na supremacia da lei [rule of law]". (BARROSO, Luís Roberto. Curso de Direito Constitucional Contemporâneo: os conceitos fundamentais e a construção do novo modelo. São Paulo: Saraiva, 2009. p. 17).

${ }^{21}$ COMPARATO, Fábio Konder. A Afirmação Histórica dos Direitos Humanos. $7^{\mathrm{a}}$ ed. São Paulo: Saraiva, 2010..p. 64.

22 “O artigo I da Declaração que 'o bom povo da Virgínia' tornou pública, em 16 de junho de 1776, constitui o registro de nascimento dos direitos humanos na História. É o reconhecimento solene de que todos os homens são igualmente vocacionados, pela sua própria natureza, ao aperfeiçoamento constante de si mesmos. A 'busca pela felicidade', repetida na Declaração de Independência dos Estados Unidos, duas semanas após é a razão de ser desses direitos inerentes à própria condição humana. (...) Treze anos depois, no ato de abertura da Revolução Francesa, a mesma ideia de liberdade e igualdade dos seres humanos é afirmada e reforçada: 'Os homens nascem e permanecem livres e iguais em direitos' [Declaração dos Direitos do Homem e do Cidadão, de 1789, art. $1^{\circ}$ ]”. (COMPARATO, Fábio Konder. A Afirmação Histórica dos Direitos Humanos. 7ª ed. São Paulo: Saraiva, 2010. p. 62).

23 “A Revolução não foi contra a monarquia, que, de início, manteve-se inquestionada, mas contra o absolutismo, os privilégios da nobreza, do clero e as relações feudais no campo. Sob o lema liberdade, igualdade $e$ fraternidade, promoveu-se um conjunto amplo de reformas antiaristocráticas, que incluíram: a] a abolição do sistema feudal; b] a promulgação da Declaração dos Direitos do Homem e do Cidadão; c] a elaboração de uma nova Constituição, concluída em 1791; d] a denominada constituição civil do clero. Essa primeira fase da revolução, que foi de 1789 a 1792, consumou o fim do Antigo Regime e pretendeu criar uma monarquia constitucional e parlamentar, em que o rei deixava de ser soberano por direito próprio e passava a ser delegado da nação.” (BARROSO, Luís Roberto. Curso de Direito Constitucional Contemporâneo: os conceitos fundamentais e a construção do novo modelo. São Paulo: Saraiva, 2009. p. 26).

${ }^{24}$ COMPARATO, Fábio Konder. A Afirmação Histórica dos Direitos Humanos. $7^{\text {a }}$ ed. São Paulo: Saraiva, 2010. p. 64.

25 "Nada obstante, a referência feita a Aristóteles como o 'constitucionalista da filosofia grega', a verdade é que, até meados do século XVIII, o problema da limitação do poder político não recebeu tratamento adequado. Somente com o iluminismo e o jusnaturalismo racionalista é que surge o constitucionalismo moderno, consagrando a ideia de separação de poderes do Estado, como forma de contê-los, e proteção de direitos individuais que precediam ao próprio Estado e deveriam ser reconhecidos pela ordem jurídica. No plano político, o surgimento do constitucionalismo coincide com a era das revoluções burguesas. A Constituição institucionaliza a conquista do Estado pela burguesia emergente, dando feição jurídica ao liberalismo. O Direito Constitucional surge, assim, como 'técnica de proteção da liberdade e da propriedade, limitando o poder 
A constituição no sentido moderno pretendeu, como vimos, radicar duas ideias básicas: (1) ordenar, fundar e limitar o poder político; (2) reconhecer e garantir os direitos e liberdades do indivíduo. Os temas centrais do constitucionalismo são, pois, a fundação e legitimação do poder político e a constitucionalização das liberdades. Procuraremos captar estes temas através de modelos teóricos o modelo historicista, o modelo individualista e o modelo estadualista. Alguma coisa do que atrás foi dito sobre o constitucionalismo antigo e sobre a constituição em sentido histórico vai estar subjacente nas considerações posteriores. O que se pretende agora é fornecer modelos de compreensão das palavras e das coisas que estão na gênese do constitucionalismo moderno. Se o constitucionalismo é uma teoria normativa do governo limitado e das garantias individuais, parece aceitável a abordagem desta teoria através de modelos, isto é, estruturas teóricas capazes de explicar o desenvolvimento da ideia constitucional.

No Brasil, o processo de constitucionalização se deu tardiamente, mas de certa forma em momento histórico ainda relativamente próximo daquele no qual se sobressaíram as experiências americana e francesa, já acima mencionadas.

\footnotetext{
monárquico, despersonalizando o direito e regulando o processo representativo.' Em uma palavra: o constitucionalismo representa a apropriação das relações e fenômenos políticos pelo Direito - a sua judicização". (BINENBOJM, Gustavo. A Nova Jurisdição Constitucional Brasileira - Legitimidade democrática e instrumento de realização. $3^{a}$ edição. Rio de Janeiro: Renovar, 2010. p. 3-4).

26 “O constitucionalismo apresenta-se inicialmente como semântica político-jurídica que reflete a pressão estrutural por diferenciação entre política e direito no âmbito da emergente sociedade multicêntrica da modernidade. Mas a semântica constitucionalista reagiu construtivamente no plano das estruturas, servindo como 'ideologia' revolucionária para o surgimento das Constituições como artefatos possibilitadores e asseguradores da diferença entre sistemas político e jurídico. Embora a semântica constitucionalista tenha surgido no centro da emergente sociedade burguesa, sobretudo na Inglaterra e na França, a afirmação de Constituição no nível estrutural apresentou-se primeiramente 'em 1776, na periferia do mundo ocidental de então, na América do Norte', só se configurando 'treze anos mais tarde, em 1789, na Europa'. (...) na Inglaterra o processo de constitucionalização teve um caráter evolutivo, não se podendo caracterizar a Revolução Gloriosa de 1688 como fundadora de uma Constituição em sentido moderno, pois ' foi uma revolução para defesa da velha ordem, nomeadamente dos direitos do parlamento, contra as intenções transformadoras da coroa.' Isso se associa com o fato de que a conversão prática da semântica constitucionalista em estruturas constitucionais pressupôs a ocorrência de revolução no sentido de rupturas com a velha ordem de poder". (NEVES, Marcelo. Transconstitucionalismo. São Paulo: WMF Martins Fontes, 2009. p. 53-4).
}

${ }^{27}$ CANOTILHO, José Joaquim Gomes. Direito Constitucional. $6{ }^{a}$ ed. Coimbra: Livraria Almedina, 1993. p. 545. 
Decerto, está-se a falar do começo do século XIX e do processo de independência de uma colônia ${ }^{28}$ que precisava de um documento de caráter político-jurídico a lhe reger. E ainda, de um contexto no qual uma elite latifundiária rica e esclarecida catalisava os ideais políticos europeus e americanos de então ${ }^{29}$, a saber, Liberalismo, Parlamentarismo, Federalismo e sobretudo, constitucionalismo ${ }^{30}$.

Ora, "o processo constitucional brasileiro inicia-se com uma singularidade: começa antes mesmo da Independência, quando o Brasil ainda era Reino Unido a Portugal"31. Enquanto o natural seria um povo conquistar a independência para só após iniciar o processo de constitucionalização. Isso, por óbvio condicionou os limites deste texto político e sua aplicabilidade, já se denunciando o caráter autoritário, artificial e oligárquico que lhe seria característico $^{32}$, notadamente a partir do Poder Moderador e estendido, sob outra roupagem, durante boa parte da história brasileira até se romper efetivamente com a promulgação da Constituicão Federal de $1988^{33}$.

\footnotetext{
${ }^{28}$ Sobre a descolonização do Brasil e a representatividade desse momento particular de que se está a tratar, vejase o quanto afirmou o historiador Laurentino Gomes a respeito: "Nenhum outro período da história brasileira testemunhou mudanças tão profundas, decisivas e aceleradas quanto os treze anos em que a corte portuguesa morou no Rio de Janeiro. Num espaço de apenas uma década e meia, o Brasil deixou de ser colônia fechada e atrasada para se tornar um país independente. Por essa razão, o balanço que a maioria dos estudiosos faz de D. João VI tende a ser positivo, apesar de todas as fraquezas pessoais do rei. Para o historiador Oliveira Lima, ele foi 'o verdadeiro fundador da nacionalidade brasileira', por duas razões principais: assegurou a integridade territorial e deu início à classe dirigente que se responsabilizaria pela construção do novo país. 'Com ele começou a descolonização efetiva', afirmou o escritor e crítico literário paranaense Wilson Martins. 'Não só pelo ato de elevar o Brasil a reino, mas também, e sobretudo, por lhe dar desde logo e sem breve espaço de tempo as estruturas de uma nação propriamente dita.' (GOMES, Laurentino. 1808: como uma rainha louca, um príncipe medroso e uma corte corrupta enganaram Napoleão e mudaram a história de Portugal e do Brasil. São Paulo: Planeta do Brasil, 2007. p. 326-7).
}

29 “Em verdade, uma nação como o Brasil é uma 'invenção' do capitalismo europeu. Em seguida, ela se torna ininteligível se não compreendemos a trama das relações com os Estados Unidos, a Alemanha, a França, a Inglaterra, a Itália, o Japão. Portanto, como povo, como organização econômica, como cultura, o Brasil é uma sucessão de desdobramentos da cultura capitalista, com centros dominantes externos. Daí a consciência infeliz de um povo que busca seu destino no espelho de outros povos, sem dispor de todas as condições para tornar-se senhor do próprio destino". (IANNI, Octávio. Raças e classes sociais no Brasil. $2^{\mathrm{a}}$ ed. Rio de Janeiro: Civilização Brasileira, 1972. p. 224).

${ }^{30}$ Cf. SILVA, José Afonso. Constitucionalismo Brasileiro: Evolução Institucional. São Paulo: Malheiros Editores, 2011. p. 26.

31 SILVA, José Afonso. Constitucionalismo Brasileiro: Evolução Institucional. São Paulo: Malheiros Editores, 2011. p. 45.

${ }^{32}$ Cf. BONAVIDES, Paulo. Curso de Direito Constitucional. 13 ${ }^{\mathrm{a}}$ ed. São Paulo: Malheiros Editores, 2003. p. 164-5. p.

${ }^{33} \mathrm{O}$ constitucionalismo brasileiro pode ser associado a duas épocas históricas distintas, a saber, a fase monárquica, com a Constituição do Império de 1824 e a fase republicana, com a Constituição de 1891 e todas 
O fato é que, ainda que haja notas singulares, o constitucionalismo aqui também representou a consagração de direitos fundamentais e limitação ao poder do Estado, embora nem sempre, tenha alcançado seu desiderato, como são exemplos os períodos ditatoriais e o próprio período imperial. Nesse sentido, a Constituição de 1824 no Brasil, a despeito de conviver paradoxalmente com o regime de escravidão, "foi a primeira Constituição a integrar no seu texto articulado uma declaração dos direitos individuais" ${ }^{34}$, isto é, "por primeira vez no mundo imprimiu à declaração de direitos, até então abstrata, o caráter de normas jurídicas positivas" ${ }^{\prime 35}$.

Pois bem, uma nota central de todo esse processo é a importância do direito vigente $^{36}$ no constitucionalismo brasileiro e também mundial. Com efeito, o Brasil, em particular, foi o primeiro a positivar os direitos fundamentais de modo expresso e analítico, de modo a, na esteira do movimento positivista ${ }^{37}$, transformar texto normativo no elemento primeiro da definição e reconhecimento de validade dos direitos. E, veja-se, sendo assim, ainda que muitos neguem ao operador do direito, seja moderno, seja em tempos passados a tarefa de simples leitor gramatical de expressões linguísticas, a sua negação, de modo irresponsável, sublinha-se, pode se mostrar muito perigosa ${ }^{38}$.

que lhe sucederam. Esta última decerto comporta subdivisões, pois durante este período várias transformações se processaram no país e as Constituições refletiram essa realidade em menor ou maior medida.

${ }^{34}$ SILVA, José Afonso. Constitucionalismo Brasileiro: Evolução Institucional. São Paulo: Malheiros Editores, 2011. p. 38.

${ }^{35}$ Idem. p. 38.

${ }^{36}$ A ideia de direito vigente recupera a de relação de poder, pois como pontua Hartmamn, "Um direito sem poder não é direito vigente". Assim como bem relatou João Maurício Adeodato, a partir desta citação do pensamento de Hartmamn, "É precisamente por força do poder que o direito se opõe ao poder do indivíduo e à sua iniciativa privada, assim como em virtude deste mesmo poder o protege dentro das fronteiras de sua liberdade jurídica, contra a iniciativa alheia. (...) $\mathrm{O}$ direito, por isso não precede a tomada do direito vigente como critério para avaliar a legitimidade ou a própria existência do poder (...) é um notório círculo vicioso que o poder se deva basear no direito e este, por sua vez, no poder. (ADEODATO, João Maurício. Filosofia do Direito: uma crítica à verdade na ética e na ciência. São Paulo: Saraiva, 2002. p. 201-2).

${ }^{37}$ Para uma melhor compreensão deste movimento e do conceito de que se vale o presente trabalho, sem os preconceitos que são dirigidos normalmente a essa escola de pensamento, veja-se o quanto está contido em Dimitri Dimoulis (DIMOULIS, Dimitri. Positivismo Jurídico: Introducão a uma teoria do direito e defesa do pragmatismo jurídico-político. São Paulo: Método, 2006); e também as palavras do professor Elival da Silva Ramos (RAMOS, Elival da Silva. Ativismo Judicial: Parâmetros Dogmáticos. São Paulo: Saraiva, 2010), mais precisamente o contido na página 35 e ss; assim como o quanto contido na obra de Noberto Bobbio, Positivismo Jurídico, já mencionada, e com atenção especial às páginas 119, p. 131-133.

${ }^{38}$ A esse respeito, confiram-se as palavras de Lenio Streck "Penso que, de algum modo, é necessário enfrentar o 'estado de natureza hermenêutica' em que se transformou o sistema jurídico. A 'liberdade' na interpretação dos textos jurídicos proporcionada pelo império das correntes (teses, teorias) ainda arraigadas/prisioneiras do 
É que, na esteira do positivismo, com supedâneo na ideia contratual, fixada em um ambiente liberal de desenvolvimento da linguagem e da imprensa, a língua e por consequente a sua peculiar expressão escrita assumem o caráter impessoal já tantas vezes buscado por estes movimentos constitucionalizantes. Decerto, o código linguístico, à medida que possa ser compartilhado pelo maior número de pessoas, através do processo de alfabetização, passa, com o predomínio do direito, a se transmudar no principal veículo de convivência entre indivíduos e a sociedade, seja no âmbito interno de um Estado, seja no conserto internacional.

Assim, não se pode, sem graves consequências, amesquinhar o texto ${ }^{39}$ sob o argumento da importância do jurista para o processo de descobrimento e aplicação do direito. Logo, ainda que o texto frio e impessoal sem o caso concreto e sem a interpretação de uma autoridade nada mais represente do que apenas um ponto de partida, a visão extremada de menosprezo destes textos ${ }^{40}$ em nada contribui para a consolidação de um ambiente democrático, atuando, em última análise, a bem da verdade, como ambiente propício ao desenvolvimento de oligarquias, tão nocivas a qualquer comunidade política.

esquema sujeito-objeto tem gerado esse 'estado de natureza interpretativo', representado por uma 'guerra de todos os intérpretes contra todos os intérpretes', como que repristinando a fragmentação detectada tão bem por Hobbes. Cada intérprete parte de um 'grau zero' de sentido. Cada intérprete reina nos seus 'domínios de sentido', com seus próprios métodos, metáforas, metonímias, justificativas e etc. Os sentidos 'lhe pertencem', como se estes estivessem a sua disposição, em uma espécie de reedição da 'relação de propriedade' (neo) feudal. Nessa 'guerra' entre os intérpretes - afinal, cada um impera solipsisticamente nos seus 'domínios de sentido' reside a morte do próprio sistema jurídico". (STRECK, Lenio Luiz. Os modelos de juiz diante da democracia e da divisão de poderes no Estado democrático de direito. In TAVARES, André Ramos; LEITE, George Salomão; SARLET, Ingo Wolfgang (orgs). Estado Constitucional e organização do Poder. São Paulo: Saraiva, 2010. p. 448).

${ }^{39}$ Quer-se aqui chamar a atenção, como adverte João Maurício Adeodato, fazendo referência a Friedrich Müller que "[...] o texto limita a concretização da norma e não permite decidir em qualquer direção, como querem diversas formas de decisionismo. Essa proeminência do aspecto formal e, consequentemente, da validade, diante de outros conteúdos presentes no cenário político e jurídico, constitui-se em um 'elemento estabilizador de primeiro nível e um pressuposto insubstituível de sociedades complexas do tipo da sociedade industrial'. (ADEODATO, João Maurício. A Retórica Constitucional: sobre tolerân sobre tolerância, direitos humanos e outros fundamentos éticos do direito positivo, São Paulo: Saraiva, 2009, p. 145-146).

${ }^{40}$ Sobre a importância do programa normativo, veja-se: “Observa-se, no âmbito deste paradigma teórico, que não só a 'norma de decisão' [norma individual], mas também a 'norma jurídica' [norma geral] é construída no processo de concretização. O texto constitucional apresenta-se, por um lado, como 'o mais importante dado de entrada' desse processo. (...) Por outro lado, a decisão concretizante deve ser reconduzível consistentemente ao texto, embora possa apresentar conteúdos os mais variáveis. Quando ocorre, porém, concretização desconstitucionalizante, não há uma relação consistente entre texto e atividades concretizantes. O texto constitucional é uma referência distante dos agentes estatais e cidadãos, cuja práxis desenvolve-se frequentemente à margem do modelo textual de Constituição.” (NEVES, Marcelo. Constitucionalização simbólica e desconstitucionalização fática: mudança simbólica da Constituição e permanência das estruturas reais de poder. Revista de Informação Legislativa, Brasília, ano 33, n. 132, p. 323, out/dez 1996). 
Demais disso, veja-se que em toda a história Constitucional brasileira não se prescindiu de uma estrutura textual e formalista a consagrar os princípios e regras básicas da política e dos direitos. E, justamente, no período mais democrático, a saber aquele surgido após a Constituição de 1988, na qual a participação popular se mostra infinitamente superior aos períodos antecedentes, é que se mostra uma tendência ao assenhoramento por parte de algumas instituições singulares e grupos sobre o conteúdo da Constituição, como se verá adiante.

E esse monopólio do conteúdo das normas acriticamente assentado no Brasil, é que se está em última análise a perquirir e dissecar, sob o prisma da mutação de normas constitucionais.

Portanto, percebemos que o movimento constitucionalista e a Constituição, como seu resultado, seja no mundo em maior medida, mas também no Brasil, estão solidificados e baseados em lutas, revoluções e rupturas de estruturas sócio-políticas, primariamente, localizadas e restritas e, após, com pretensões de universalização, como hoje temos assistido, e já o vimos a partir da própria Revolução Francesa. É um processo de consolidação de valores e estruturação das sociedades, a partir de uma linguagem a todos comum, e sobretudo escrita, no sentido de positivada. E essa positivação dos direitos é que se quer por em evidência aqui e discutir.

Pois bem, após essa breve análise do constitucionalismo, e suas características reinantes, passa-se ao conceito atual de Constituição de que se vale este trabalho para fins de desenvolvimento do tema da mutação, integrando todos os elementos vistos até então.

\subsection{Da Constituição e do estado de coisas que a cerca}

A teoria constitucional, como visto acima, nos moldes da construção empreendida no mundo ocidental só foi possível graças à crença em um ideal, segundo o qual a limitação do poder e a enunciação de liberdades e garantias individuais seriam os pressupostos da edificação de uma sociedade justa, plural e participativa. 
Observa-se, no padrão amplamente aceito, que as Constituições possuem um papel funcional-estrutural de organização do poder e um papel político e jurídico de estabelecer uma mediação entre o exercício dos direitos pelo indivíduo e a ação do Estado.

A Constituição fez com que a política não gozasse mais da liberdade atribuída aos monarcas absolutistas de outrora. Contudo, nas palavras de Dieter Grimm, ela não eliminou a política, apenas lhe colocou uma moldura ${ }^{41}$.

Esse fenômeno não significou uma completa amarra da política pelo direito, pois, criaram-se uma série de procedimentos que normatizaram o processo decisório, mantendo sua independência. Logo, tais meios não foram capazes de se sobrepor, ou mesmo, substituírem-se ao debate político, posto que o direito é incapaz de "normatizar antecipadamente o insumo para o processo decisório" 42 e, como instrumento, apenas garante a justiça do debate, mas não necessariamente a justiça da decisão.

Contemporaneamente, a Constituição, herdeira do espólio político institucional, relatado no item precedente deste capítulo, ao mesmo tempo em que propicia e fomenta mudanças da realidade ${ }^{43}$, igualmente, é influenciada por estas ${ }^{44}$, mantendo-se,

\footnotetext{
${ }^{41}$ Com efeito, "a pretendida limitação da disposição política sobre o direito só podia ser alcançada por intermédio do próprio direito. E esse direito devia ser superior ao direito estabelecido, mas não suprapositivo". (GRIMM, Dieter. Constituição e Política. Geraldo de Carvalho (Trad). Belo Horizonte: Del Rey, 2006. p. 9-10). ${ }^{42}$ Idem, ibide. p. 10-11.

${ }^{43}$ Sobre o tema discorre Konrad Hesse, "Graças à pretensão de eficácia, a Constituição procura imprimir ordem e conformação à realidade política e social. Determinada pela realidade social e, ao mesmo tempo, determinante em relação a ela, não se pode definir como fundamental nem a pura normatividade, nem a simples eficácia das condições sócio-políticas e econômicas. A condicionante da realidade e a normatividade da Constituição podem ser diferençadas; elas não podem, todavia, ser definitivamente separadas ou confundidas". (HESSE, Konrad. $A$ força normativa da Constituição. Gilmar Ferreira Mendes (Trad.). Porto Alegre: Sérgio Antonio Fabris Editor, 1991. p. 15).

${ }^{44}$ Sobre tais adequações, destaca Niklas Luhman: "A linha geral da mudança evolutiva da estrutura está clara: se as conquistas evolutivas devem ser estabilizadas, então as estruturas devem permitir mais ações, por seu lado, mais variadas, ou seja, devem ser compatíveis com um número maior de situações no sistema social - ou seja, devem permitir maiores liberdades. Por outro lado, tendo em vista a constante oferta superabundante de expectativas normativas, as estruturas devem possuir mais possibilidades de rejeitar expectativas; a possibilidade de dizer não, tem que ser fortalecida. Nesse sentido geral e quase vazio pode-se falar de uma inevitabilidade da evolução (...) Isso tudo não representa um processo necessário, mas apenas um processo possível e que participa da criação de suas próprias condições, através da formação de sistemas. Para compreendê-lo como processo temos que voltar-nos para a teoria da evolução. Parece que tanto no campo orgânico quanto no sentido da evolução de sistemas complexos é necessária a ação conjunta de três tipos de mecanismos: (1) mecanismos de geração da variedade no sentido de uma superprodução de possibilidades; (2) mecanismos de seleção das possibilidades aproveitáveis; (3) mecanismos de manutenção e estabilização das possibilidades escolhidas, apesar do campo de escolha permanecer complexo e contingente". (LUHMANN, Niklas. Sociologia do Direito I. Gustavo Bayer (Trad.). Rio de Janeiro: Edições Tempo Brasileiro, 1983. p. 175).
} 
decerto, como importante fator de tomada de decisão política na era vigente, mas não o único e mais influente.

Deveras, pois, ela passa a concorrer com outros fatores determinantes e relevantes para o processo decisório, que inclusive controlam, em certa medida, a escolha do conteúdo dos preceitos jurídicos.

Nesse prisma, como bem pontua Ulrich Beck $^{45}$, na atualidade, caminha-se para uma subvalorização da política tradicional como canal primordial do processo decisório, pois outros canais, em rede, abrem-se, e o presente e futuro das sociedades ${ }^{46}$ acaba por se construir à margem da política e do direito, senão vejamos:

Enquanto a política, com a ampliação do Estado Social, esbarra em fronteiras e contradições imanentes, perdendo seu ímpeto utópico, acumulam-se as possibilidades de transformação social na colaboração entre pesquisa, tecnologia e economia. Sem que se alterem a estabilidade institucional e as atuais competências, o poder constitutivo migra do âmbito da política para o da subpolítica. Nas discussões contemporâneas, já não se espera que a 'outra sociedade' chegue através dos debates parlamentares sobre as novas leis, e sim através da aplicação da microeletrônica, da tecnologia genética e dos meios de informação (grifos nossos).

Deste modo, nota-se que outros aspectos, que não apenas àqueles relacionados estritamente à política e ao direito, passam a influenciar eficazmente o processo decisório institucional, a exemplo do empoderamento conferido a determinados setores, com fundamento simplesmente no desenvolvimento e avanço do conhecimento científico e tecnológico. Trata-se, dentre outros, do reconhecimento do saber, como fonte essencial das

\footnotetext{
${ }^{45}$ BECK, Ulrich. Sociedade de Risco: rumo a uma outra modernidade. $2^{\mathrm{a}}$ ed. Sebastião Nascimento (Trad.). São Paulo: Editora 34, 2011. p. 326-7.

${ }^{46}$ Para um panorama preciso da atual concepção de sociedade, veja-se a definição do sociólogo polonês, Zygmunt Bauman: "A 'sociedade' é cada vez mais vista e tratada como uma 'rede' em vez de uma 'estrutura' [para não falar em uma 'totalidade sólida']: ela é percebida e encarada como uma matriz de conexões e desconexões aleatórias e de um volume essencialmente infinito de permutações possíveis". (BAUMAN, Zygmunt. Tempos Líquidos. Carlos Alberto Medeiros (Trad.). Rio de Janeiro: Zahar, 2007. p. 9).
} 
decisões sociais em detrimento de processos baseados exclusivamente em entendimentos políticos, amparados por debate de ideais.

Assim, o próprio direito e a Constituição, escrita e rígida, baluartes da limitação do Poder, vivem hoje um novo processo, de certo modo até minimético, pois como forma de recuperar seu papel central, a leitura que se faz hoje dos preceitos constitucionais acaba-se por se confundir com outros sistemas, integrando a seu conteúdo, métodos que não lhe são próprios e tradicionais, em franca oposição à separação característica do positivismo entre ser e dever-ser.

Logo, a Constituição enquanto direito tem que ser vista "como uma estrutura cujos limites e cujas formas de seleção (de conteúdos) são definidos pelo sistema social. ${ }^{, 47} \mathrm{E}$ como a Constituição "não é de nenhuma forma a única estrutura social, devem ser consideradas as estruturas cognitivas, os meios de comunicação e o esquema de diferenciação de sistemas na sociedade (...)"48.

Acontece que, nesse ambiente, o texto escrito e a rigidez ${ }^{49}$ parecem cada vez mais perderem importância diante dos novos fatores (cognitivos, comunicacionais e sistemáticos) de exercício de Poder, como a técnica, o capital e tantos outros. Essa concorrência tem, de certo modo, provocado uma reinvenção de alguns caracteres funcionais da Constituição, lançando novas luzes sobre a relação norma, intérprete e realidade.

Nesses termos, a Constituição ${ }^{50}$, que nasceu como domesticadora da política e fundamento e disciplina do poder, agora se vê, como documento escrito e estável,

\footnotetext{
${ }^{47}$ LUHMANN, Niklas. Sociologia do Direito I. Gustavo Bayer (Trad.). Rio de Janeiro: Edições Tempo Brasileiro, 1983. p. 170.

${ }^{48}$ Idem, ibidem.

${ }^{49}$ Como bem pontua Oscar Vilhena, "no processo constituinte a rigidez não funciona como simples autolimitação, mas também como limitação àquelas correntes que, vencidas no embate constituinte, podem se converter em maiorias no futuro e alterar o decidido no processo de elaboração da Constituição. No dizer de Carl Schmitt as limitações materiais ao poder de reforma buscam, antes de tudo, fechar a porta aos inimigos derrotados na assembléia constituinte. Assim é que a Constituição Francesa de 1884, ou a brasileira de 1891, definem a República como preceito inalterável, fechando as portas aos monarquistas, inimigos da Constituição". (VILHENA, Oscar. A Constituição como reserva de justiça. Revista Lua Nova, São Paulo, n ${ }^{\circ}$ 42-97, p. 54, 2005).

${ }^{50}$ Para um conceito ideal de Constituição, veja-se CANOTILHO, José Joaquim Gomes. Direito Constitucional. $6^{\mathrm{a}}$ ed. Coimbra: Livraria Almedina, 1993. p. 62-3.
} 
extremamente fragilizada e instabilizada pela sociedade de risco, fluida e líquida ${ }^{51}$ que se experimenta, fazendo do projeto constitucional algo não dotado de uma identidade única e reconhecível a princípio ${ }^{52}$, como era tão claro e evidentemente perceptível na Magna Carta e nas Declarações do Século XVIII.

E, caso tomemos como parâmetro os dados e a percepção que nos levaram a pontuar quanto a tais documentos a existência de uma força normativa suficientemente rígida a pautar a sociedade e não apenas refletir seus fatores reais de poder, tal qual já nos legou Ferdinand Lassalle ${ }^{53}$, tenderemos a afirmar que essa força vive uma crise.

A Constituição, todavia, tem mostrado resquícios de força a partir justamente desta ressignificação dos direitos ${ }^{54}$, sobretudo dos direitos fundamentais, demonstrando uma capacidade enorme de adaptação dos seus preceitos à passagem do tempo ${ }^{55}$, sendo capaz de apresentar, mediante a atividade de seus atores ${ }^{56}$, respostas eficazes aos problemas

\footnotetext{
${ }^{51}$ Para uma completa apreensão do termo "modernidade líquida", sugere-se a leitura das obras de Zigmunt Bauman, a saber: BAUMAN, Zygmunt. Modernidade Líquida. Plínio Dentzien (Trad.). Rio de Janeiro: Zahar, 2001; BAUMAN, Zygmunt. Tempos Líquidos. Carlos Alberto Medeiros (Trad.). Rio de Janeiro: Zahar, 2007 e BAUMAN, Zygmunt. Medo Líquido. Carlos Alberto Medeiros (Trad.). Rio de Janeiro: Zahar, 2008.
}

${ }^{52}$ Nas precisas lições de Zigmunt Bauman, "Grande parte do poder de agir efetivamente, antes disponível ao Estado moderno, agora se afasta na direção de um espaço global [e, em muitos casos, extraterritorial] politicamente descontrolado, enquanto a política - a capacidade de decidir a direção e objetivo de uma ação - é incapaz de operar efetivamente na dimensão planetária, já que permanece local. A ausência de controle político transforma os poderes recém-emancipados numa fonte de profunda e, em princípio, incontrolável incerteza, enquanto a falta de poder torna as instituições políticas existentes, assim como suas iniciativas e seus empreendimentos, cada vez menos relevantes para os problemas existenciais dos cidadãos dos Estados-nações e, por essa razão, atraem cada vez menos a atenção destes”. (BAUMAN, Zygmunt. Tempos Líquidos. Carlos Alberto Medeiros (Trad.). Rio de Janeiro: Zahar, 2007. p. 8 grifos nossos).

${ }^{53}$ LASSALE, Ferdinand. A Essência da Constituição. 9a edição. Rio de Janeiro: Lumen Juris, 2010.

${ }^{54}$ Sobre a dinamicidade do direito, traz-se à colação as palavras de Eros Roberto Grau: "O direito é produto histórico, cultural, está em contínua evolução. Dele dizia Von Ihering (1900-8-9) ser qual Saturno, que devora seus próprios filhos e rejuvenesce superando o seu próprio passado. Como a realidade, onde nasce em relação à qual se põe, não é estático." (GRAU, Eros Roberto. O direito posto e o direito pressuposto. $7^{\mathrm{a}}$ ed. São Paulo: Malheiros, 2008. p. 22-23).

${ }^{55}$ Sobre as implicações atuais acerca do conflito geracional que as Constituições proporcionam, confira HÄRBELLE, Peter. A jurisdição constitucional na sociedade aberta. In TAVARES, André Ramos; LEITE, George Salomão; SARLET, Ingo (orgs). Estado constitucional e organização do poder. São Paulo: Saraiva, 2010. p. 136 e ss.

${ }^{56}$ Sobre o papel proeminente do Judiciário, atente-se para o que destaca Leonardo Martins, sobretudo, os seus questionamentos finais, abaixo destacado: "Em face da inércia Legislativa e muitas vezes incompetência da burocracia administrativa, a tentação do ativismo judicial é muito grande. Juízes muito bem intencionados, a partir de provocações de órgãos do Ministério Público igualmente bem-intencionados, tomam as rédeas e condenam órgãos públicos e às vezes até privados às prestações de direitos fundamentais prestacionais e sociais. 
contemporâneos, ainda que estas não sejam, necessariamente, passíveis de recondução ao conteúdo original consagrado pelo constituinte.

Esse atual estado de coisas vem sendo acompanhado de uma supervalorização e identificação/criação de princípios constitucionais, conjugada a um superdimensionamento dos direitos fundamentais, como já destacado, sobretudo os de primeira e segunda geração, que passam a exercer uma força normativa diferenciada, permeável constantemente a novos conteúdos normativos, ainda que não mediados pelo legislador ${ }^{57}$. Isso tem tornado a normatividade constitucional sempre atual, embora inserta em um contexto de fluidez e multipolarização de valores, fontes que tem alimentado essa elasticidade constitucional ${ }^{58}$.

As consequências desta constatação é que serão objeto do item a seguir, sobretudo acerca da tensão entre norma e realidade ${ }^{59}$, diante da inserção constante de múltiplos conteúdos cujo objetivo primordial tem sido adequar o direito à realidade

\begin{abstract}
(...) a concretização de direitos fundamentais sociais fica a cargo da discricionariedade judicial, vale dizer, dependente de juízos de valor e de boa vontade de juízes singulares e órgãos judiciários colegiados que não têm competência constitucional nem legitimidade democrática para tanto. (...) O problema é menos complexo quando a omissão é meramente administrativa, pois a Administração Pública está toda vinculada negativa e positivamente aos direitos fundamentais. Por sua vez, no campo das omissões legislativas, a racionalidade e dogmáticas jurídicas alcançam seus limites de atuação: Não há o que fazer se não constatar a omissão inconstitucional e esperar que o parlamento a saneie. Trata-se de um teste para a maturidade de uma democracia representativa, teste esse pelo qual ela deve passar. Não há como ser transferido à corte suprema ou tribunal constitucional; a não ser que queiramos transformar o Estado democrático de direito em uma aristocracia judicial. Um governo de juízes significaria a quebra da ordem constitucional vigente. Será que nosso ceticismo em face da democracia representativa nos levará tão longe? Qual é o papel da ciência do direito constitucional neste contexto? (MARTINS, Leonardo. Igualdade e Liberdade na Justiça Constitucional. In TAVARES, André Ramos; LEITE, George Salomão; SARLET, Ingo Wolfgang (orgs). Estado Constitucional e organização do Poder.. São Paulo: Saraiva, 2010. p. 477-478. grifos nossos).
\end{abstract}

57 "Observe-se como, nos dias atuais, correntes como o uso alternativo do direito, o ativismo judicial ou a hermenêutica filosófica, apesar de suas diferenças, propugnam exatamente por uma politização do judiciário, entendendo-o criador de direito e realizador de demandas sociais em defesa dos cidadãos e minorias menos privilegiadas economicamente." (ADEODATO, João Maurício. A Retórica Constitucional: sobre tolerância, direitos humanos e outros fundamentos éticos do direito positivo. São Paulo: Saraiva, 2009. p. 156.)

58 Sobre mudança social e sua influência na dogmática, confira-se ZAGREBELSKY, Gutavo. El Derecho Dúctil: Ley, derechos, justicia. Marina Gascón (Trad). Madrid: Editorial Trotta, 2011. p. 17.

${ }^{59}$ Sobre o tema da tensão entre realidade e norma constitucional, vejam-se as palavras de Konrad Hesse: "Não se deve esperar que as tensões entre ordenação constitucional e realidade política e social venham a deflagrar sério conflito. Não se poderia, todavia, prever o desfecho de tal embate, uma vez que os pressupostos asseguradores da força normativa da Constituição não foram plenamente satisfeitos. A resposta à indagação sobre se o futuro do nosso Estado é um questão de poder ou um problema jurídico depende da preservação e do fortalecimento da força normativa da Constituição, bem como de seu pressuposto fundamental, a vontade de Constituição. Essa tarefa foi confiada a todos nós" (HESSE, Konrad. A força normativa da Constituição. Gilmar Ferreira Mendes (Trad.). Porto Alegre: Sérgio Antonio Fabris Editor, 1991. p. 32). 
circundante, ainda que tal adequação não seja, reitere-se, necessariamente, precedida de um debate responsável quanto à inovação que se empreende no mundo normativo.

\subsection{Da mutação constitucional e das suas modalidades de verificação}

Sabe-se que a possibilidade de se mudar o conteúdo original ou ordinário de um preceito normativo, seu texto, nem sempre acompanha pari passu a contemporaneidade das relações sociais. É que a velocidade de tais transformações tem-se mostrado intangível pela ordem jurídica legislada. Isso tem levado a uma sobreposição de práticas heteronormativas sobre os conteúdos primários das normas, uma vez que os instrumentos formais disponíveis para reforma da Constituição parecem ineficientes e incapazes de permeabilizar todo esse processo de mudança social complexa, pujante e instantânea ${ }^{60}$.

Sendo assim, a Constituição necessita ser dotada da capacidade de dialogar com seu futuro, de admitir mudanças ${ }^{61}$, ainda que informais, inclusive pela atuação de uma corte constitucional, a qual deverá ser capaz de adequar as exigências normativas às necessidades vindouras ${ }^{62}$, sob pena de, em assim não fazendo, perpetuar uma desconexão entre a realidade social e o direito vigente ${ }^{63}$, corroendo e desvalorizando as normas jurídicas

\footnotetext{
${ }^{60}$ É um processo no qual "as palavras das leis conservam-se imutáveis, mas a sua acepção sofre um processo de erosão ou, ao contrário, de enriquecimento, em virtude da interferência de fatores diversos que vêm amoldar a letra da lei a um novo espírito, a uma imprevista ratio juris, que atribui nova direção aos enunciados. (COELHO, Inocêncio Mártires. Interpretação Constitucional. $4^{\mathrm{a}}$ ed. São Paulo: Saraiva, 2011.p. 180).

${ }^{61}$ Contudo, como bem pontua Lênio Luiz Streck, há de se ter em mente que "em determinadas situações, mutação constitucional pode significar, equivocadamente, a substituição do poder constituinte pelo Poder Judiciário. E, com isso, soçobra a democracia”. Streck, Lenio Luiz in A nova perspectiva do Supremo Tribunal Federal sobre o controle difuso: mutação constitucional e limites da legitimidade da jurisdição constitucional, disponível em $<$ http://jus2.uol.com.br/doutrina/texto.asp?id=10253\&p=1, acesso em 03 de novembro de $2009>$.

${ }^{62}$ Conforme destaca Larenz, "É também possível que uma interpretação que aparecia originariamente como conforme à Constituição, deixe de o ser na seqüência de uma modificação das relações determinantes. Então é de escolher a interpretação, no quadro das possíveis, segundo os outros critérios de interpretação, que seja agora a única conforme a Constituição". (LARENZ, Karl. Metodologia da Ciência do Direito. 3ª ed. Lisboa: 1997,. p. 495).

${ }^{63}$ Ocorre que tal diálogo não significa menosprezar o espírito e a função fundamental da Constituição, ou seja, a sua força normativa, bem como ignorar a legitimidade do parlamento e a representatividade deste Poder e dos partidos políticos que o compõe.
} 
postas. Trata-se da necessidade de uma leitura "sempre renovada das mensagens enviadas pelo constituinte" ${ }^{\prime 64}$.

A mutação constitucional ${ }^{65}$ é o principal instituto catalisador desta situação, pois a partir de uma ressignificação dos direitos de matriz constitucional ${ }^{66}$, a Constituição estabelece um diálogo profícuo com seu tempo e seu contexto sócio, político e econômico.

A mutação constitucional, todavia, não é só uma mudança interpretativa perante uma integridade textual, mas também é acréscimo ou supressão de conteúdo normativo, bem como aplicação e interpretação de costumes constitucionais.

Nesse sentido, vejam-se as palavras de Luís Roberto Barroso ${ }^{67}$ e Karl Larenz ${ }^{68}$, “(...) é possível dizer-se que a mutação constitucional consiste em uma alteração do significado de determinada norma da Constituição, sem observância do mecanismo constitucionalmente previsto para as emendas e, além disso, sem que tenha havido qualquer modificação de seu texto. Este novo sentido ou alcance do mandamento constitucional pode decorrer de uma mudança na realidade fática ou de uma nova percepção do Direito, uma releitura do que deve ser considerado ético ou justo. Para que seja legítima, a

\footnotetext{
${ }^{64}$ COELHO, Inocêncio Mártires. Interpretação Constitucional. $4^{\mathrm{a}}$ ed. São Paulo: Saraiva, 2011. p. 181.

${ }^{65}$ J. J. Gomes Canotilho, ao tratar da mutação constitucional, chega a denomina-la como "transição constitucional, como se percebe no seguinte excerto: “(...) considerar-se-á como transição constitucional a revisão informal do compromisso político formalmente plasmado na constituição sem alteração do texto constitucional. Em termos incisivos: muda o sentido sem mudar o texto.” (CANOTILHO, José Joaquim Gomes. Direito Constitucional. $6^{\text {a }}$ ed. Coimbra: Livraria Almedina, 1993. p. 1228. grifo nosso).
}

\begin{abstract}
${ }^{66}$ Nesse sentido, advirta-se como Müller, que "A jurisprudência constitucional demonstra que as normas que deve concretizar não satisfazem, muitas vezes nem remotamente, as exigências que a lógica formal tem de estabelecer como premissas maiores para poder trabalhar com elas por meio de conclusões silogísticas. As normas constitucionais não aparecem na prática como juízos hipotéticos logificados, como ordens idênticas a seu tenor literal, senão como regulações que além dos recursos metodológicos tradicionais, necessitam de numerosos elementos interpretativos procedentes da realidade social normatizada, que não podem ser extraídos mediante as regras clássicas da interpretação nem do preceito e de seu gênese, nem do contexto sistemático de seu significado. (MÜLLER, Friedrich. O Novo Paradigma do Direito: introdução à teoria e metódica estruturante. $3^{\mathrm{a}}$ edição revista, atualizada e ampliada. São Paulo: Editora Revista dos Tribunais, 2013. p. 20).
\end{abstract}

${ }^{67}$ BARROSO, Luís Roberto. Mutação Constitucional. In GONÇALVES JÚNIOR, Jerson Carneiro; BETTINI, Lúcia Elena Polletti; MOREIRA, Eduardo Ribeiro (orgs). Hermenêutica Constitucional - homenagem aos 22 anos do Grupo de Estudo Maria Garcia. Florianópolis: Conceito Editorial, 2010. p. 430.

${ }^{68}$ LARENZ, Karl. Metodologia da Ciência do Direito. $3^{\mathrm{a}}$ ed. Lisboa: 1997.p. 495 e pp. 498-500. 
mutação precisa ter lastro democrático, isto é, deve corresponder a uma demanda social efetiva por parte da coletividade, estando respaldada, portanto, pela soberania popular.

De entre os factores que dão motivo a uma revisão e, com isso, freqüentemente, a uma modificação da interpretação anterior, cabe uma importância proeminente à alteração da situação normativa. Trata-se a este propósito de que as relações fácticas ou usos que o legislador histórico tinha perante si e em conformidade aos quais projectou a sua regulação, para os quais a tinha pensado, variaram de tal modo que a norma dada deixou de se 'ajustar' às novas relações. É o factor temporal que se faz notar aqui. Qualquer lei está, como facto histórico, em relação actuante com o seu tempo. Mas o tempo também não está em quietude; o que no momento da gênese da lei actuava de modo determinado, desejado pelo legislador, pode posteriormente actuar de um modo que nem sequer o legislador previu, nem, se o pudesse ter previsto, estaria disposto a aprovar. Mas, uma vez que a lei, dado que pretende ter também validade para uma multiplicidade de casos futuros, procura também garantir uma certa constância nas relações inter- humanas, a qual é, por seu lado, pressuposto de muitas disposições orientadas para o futuro, nem toda a modificação de relações acarreta por si só, de imediato, uma alteração do conteúdo da norma. Existe a princípio, ao invés, uma relação de tensão que só impele a uma solução - por via de uma interpretação modificada ou de um desenvolvimento judicial do Direito - quando a insuficiência do entendimento anterior da lei passou a ser 'evidente'. (texto conforme consta no original).

Demais disso, a mutação constitucional se opõe à reforma constitucional formal, parlamentar, ou seja, ao processo de inserção de emendas constitucionais, e por outro lado, também implica uma alteração judicial, executiva ou legislativa ordinária do alcance e significado de normas constitucionais, tornando o processo de adaptação e releitura ${ }^{69}$ muito mais célere do que aquela árdua mudança formal própria de uma Constituição rígida.

\footnotetext{
${ }^{69}$ Cf. Hsü Dau-Lin, quando o mesmo afirma haver, de forma geral, nas mutações constitucionais uma incongruência entre as normas constitucionais por um lado e a realidade constitucional por outro. (DAU-LIN, Hsü. Mutación de La Constitución. Pablo Lucas Verdú e Christian Förster (Trads). Oñati: IVAP, 1998. p. 29).
} 
Essa definição consagrada há mais de um século por Georg Jellinek, em 1906, apesar de um ponto partida relevante para a definição do conteúdo do que admitimos como mutação constitucional ${ }^{70}$, comporta adição ${ }^{71}$.

Deveras, a mutação, hoje, estirpando a desconfiança ínsita a uma ideia informal de mudança da Constituição, passa a integrar e mediar a própria natureza da relação constitucional entre normatividade, papel do intérprete, realidade e passagem do tempo ${ }^{72}$, apartando-se da separação estrita e arraigada no binômio ser e dever-ser. Pois se assim não se pensar, as mutações tornam-se uma disfunção insuperável do sistema, afinal a não correpondência entre ser e deve-ser proporcionada pela mutação, não se sustentaria em um ambiente de prevalência desta dicotomia, visto que a mutação significa, em última instância, corrosão desta relação.

Pois bem, no presente trabalho, seguindo os ensinamentos de Hsü Dau-Lin ${ }^{73}$, identifica-se quatro modalidades cujas características se sobressaem como elementos diferenciadores e específicos de reconhecimento de uma mutação constitucional ${ }^{74}$ e 75 . Em cada tipo, destaca-se uma característica principal, a saber, a desconexão entre realidade e

\footnotetext{
${ }^{70}$ JELLINEK, G. Reforma y Mutacion de la Constitucion. Christian Förster (Trad.). Centro de Estudios Constitucionales, Madrid, 1991.p. 7.

${ }^{71}$ DAU-LIN, Hsü. Mutación de La Constitución. Pablo Lucas Verdú e Christian Förster (Trads). Oñati: IVAP, 1998. p. 29.

${ }^{72} \mathrm{Na}$ atualidade, norma, realidade e programa normativo passam a integrar um mesmo processo em um amálgama capaz de ruir aquela separação estanque característica de um positivismo mais exacerbado, fazendo como que a não correspondência da norma à realidade, ou mesmo a sua adaptação não mais representem um problema insuperável relativo à força normativa da Constituição.
}

${ }^{73}$ DAU-LIN, Hsü. Mutación de La Constitución. Pablo Lucas Verdú e Christian Förster (Trads). Oñati: IVAP, 1998.

${ }^{74}$ Para o professor Marcelo Neves, apenas duas modalidades seriam dignas de nota, a saber: "mudanças decorrentes da interpretação/aplicação constitucional; alterações resultantes da praxis política independentemente de atividade hermenêutica em face do texto constitucional". (NEVES, Marcelo. Constitucionalização simbólica e desconstitucionalização fática: mudança simbólica da Constituição e permanência das estruturas reais de poder. Revista de Informação Legislativa, Brasília, ano 33, n. 132, p. 322, out/dez 1996.).

${ }^{75}$ Anna Cândida da Cunha Ferraz chama a atenção para o sincretismo que se observa quando se estuda o instituto, no qual se costumam associar, sob seu rótulo, diversos fenômenos, quais sejam: "mutação tácita, desconstitucionalização, anomia constitucional, falseamentos constitucionais, quebramentos constitucionais, etc" (FERRAZ, Anna Cândida da Cunha. Mutação, Reforma e Revisão de Normas Constitucionais. Revista dos Tribunais, ano 2, n. 5, p. 17, out/dez. 1993. Cadernos de Direito Constitucional e Ciência Política). 
texto; a interpretação ${ }^{76}$ inovadora e integradora; a obsolescência da norma constitucional e a alteração inconstitucional da normatividade de um preceito.

Tratemos de cada uma em separado, para, em seguida, no capítulo II, melhor desenvolver cada tipo, a partir da análise dos julgados do Supremo Tribunal Federal representativo de cada conceito explanado.

Todavia, sublinha-se, desde já, que não existe um tipo puro, e sim uma predominância, no caso específico, de uma característica perante outra. E mais, a interpretação é um fator primordial e desencadeador de cada um dos quatro tipos, seja maior ou menor medida, a depender do caso concreto.

\subsection{Mutação constitucional a partir da desconexão entre realidade e norma}

A Constituição positiva não deve ser reduzida tão somente a seus preceitos normativos, ela também incorpora algo vivo da realidade que se traduz em seu aplicar, ainda que não mediada por órgão Judiciário. Nesse sentido, tanto o Poder Legislativo, como o Poder Executivo, e mais precisamente a própria sociedade ${ }^{77}$ estabelecem práticas referenciadas ao

\footnotetext{
76 “A interpretação constitucional revela-se processo de mutação constitucional sempre que, pela via interpretativa, ao significado da norma constitucional se atribui novo conteúdo, ou se amplia a abrangência da norma para alcançar situações e relações dantes não consideradas como nela incluídos (...) A mutação constitucional por via interpretativa é claramente perceptível numa das situações seguintes: a) quando há um alargamento do sentido do texto constitucional, aumentando-se-lhe, assim, a abrangência para que passe a alcançar novas realidades; b) quando se imprime sentido determinado e concreto ao texto constitucional, visando à integração e efetiva aplicação da norma em momento diverso daquele em que ela foi estabelecida; c) quando se modifica interpretação constitucional anterior e se lhe imprime novo sentido, atendendo à evolução da realidade constitucional; d) quando há adaptação do texto constitucional à nova realidade social, não prevista no momento de elaboração da Constituição; e) quando há adaptação do texto constitucional para atender exigências do momento da aplicação constitucional; f) quando se preenche, por via interpretativa, lacunas do texto constitucional". (FERRAZ, Anna Cândida da Cunha. Mutação, Reforma e Revisão de Normas Constitucionais. Revista dos Tribunais, ano 2, n. 5, pp. 19-20, out/dez. 1993. Cadernos de Direito Constitucional e Ciência Política).

77 "Uma tentativa especial, de transpor a 'sociedade aberta' de Popper para a ciência jurídica constitucional, foi e continua sendo o paradigma da 'sociedade aberta dos intérpretes da Constituição'. Desenvolvida em 1975, e transferida recentemente para a futura Constituição da Europa, ela inclui os cidadãos, cada cidadão, no processo da interpretação constitucional. O lema chama-se 'Constituição para todos' e 'de todos'. Cada um que vive a Constituição interpreta-a num sentido mais amplo e profundo. Referimo-nos não apenas ao âmbito dos direitos fundamentais, cujo titular efetiva, ou seja, 'interpreta', no que diz com a sua designada 'autocompreensão', como é o caso da liberdade religiosa (...) Também o cidadão que apresenta uma reclamação constitucional, e que, portanto, se manifesta perante o Tribunal Constitucional Federal, é um intérprete constitucional neste sentido
} 
conteúdo das normas constitucionais ${ }^{78}$, que podem destoar ${ }^{79}$ da fiel observância do texto normativo constitucional.

Tais situações amplas não serão por nós abordadas neste trabalho, pois aqui, o objeto de preocupação se restringe às mutações constitucionais derivadas da prática de atividade judicial. E, portanto, nos será de todo importante, a análise da jurisprudência do Supremo Tribunal Federal, seus posicionamentos interpretativos, notadamente àqueles que instauram e efetivam uma verdadeira mutação constitucional, ainda que essa haja perdido como referencial qualquer norma constitucional mais fechada.

Logo, esclarece-se que aqui se discute apenas o papel do Judiciário perante as mutações constitucionais. E mais, toma-se como premissa que uma mutação só assim pode ser chamada, à medida que, um canal oficial, no caso, o Poder Judiciário assim reconhece.

Deste modo, ainda que a realidade se mostre totalmente contrária aos preceitos constitucionais, enquanto não "recepcionado" por um órgão oficial, não podemos qualificar isto como direito, e, por consequência, como mutação, sendo apenas e puramente costume, que, enquanto não oficializado, não importa mutação da Constituição, pois esta exige reconhecimento.

Pois bem, sabe-se que o modelo de separação absoluta e rígida entre realidade e texto normativo tem passado por algumas reflexões ${ }^{80}$ e a teoria do direito tem avançado para lançar novas luzes sobre esta dicotomia.

mais amplo. (...) (O termo sociedade aberta dos intérpretes da Constituição) está tendo, atualmente, um reconhecimento instigante, sobretudo na América Latina, especialmente no Brasil.” (HÄRBELLE, Peter. A jurisdição constitucional na sociedade aberta. In TAVARES, André Ramos; LEITE, George Salomão; SARLET, Ingo (orgs). Estado constitucional e organização do poder. São Paulo: Saraiva, 2010. p. 126-7).

${ }^{78}$ Nesse sentido, veja-se o quanto se dá quanto ao procedimento de votação de vetos presidenciais pelo Congresso Nacional, que se seguido a rigor os preceitos constitucionais, muitas pautas teriam sido trancadas e pouca atividade legislativa teria sido realizada nos últimos vinte e cinco anos, a não ser votar adequação de vetos presidenciais.

${ }^{79}$ Utiliza-se o termo destoar, aqui, no sentido de diferente e não necessariamente contrário ao preceito textual normativo.

${ }^{80}$ Cf. NEVES, Marcelo. Entre hidra e Hércules: princípios e regras constitucionais como diferença paradoxal do sistema jurídico. São Paulo: WMF Martins Fontes, 2013. MÜLLER, Friedrich. O Novo Paradigma do Direito: introdução à teoria e metódica estruturante. $3^{a}$ edição revista, atualizada e ampliada. São Paulo: Editora Revista dos Tribunais, 2013. RAZ, Joseph. O Conceito de Sistema Jurídico: uma introdução à teoria dos sistemas jurídicos. Maria Cecília de Almeida (Trad.); revisão de tradução de Marcelo Brandão Cipolla. São Paulo: 
Com efeito, segundo a teoria estruturante do Direito de Müller ${ }^{81}$, a realidade, o texto e a norma jurídica, integram um processo mais homogêneo de interdependência, rompendo com a divisão estanque, característica do positivismo clássico, baseado no confronto entre âmbito normativo (realidade) e programa normativo (norma), como acima já salientado.

No modelo proposto por Müller, há uma espécie de conduta auto-referencial entre realidade e norma, de modo que a própria norma é resultado em alguma medida do quanto descrito na realidade, ao passo que, também não se lhe dispensa a intenção de conformar esta mesma realidade.

Nesse sentido, pela teoria estruturante, fato e texto integram a normatividade, logo, não haveria oposição suficiente para se cogitar acerca do fenômeno da mutação constitucional, enquanto mudança informal ${ }^{82}$. Contudo, não é disso de que se está a tratar.

É que, associar a normativade a texto e realidade não significa subjugar o primeiro pela verificação do segundo. Com efeito, há apenas uma espécie de troca e de influência mútua, de tal modo que, alterações da realidade, seguida da consequente alteração do conteúdo normativo, importam sim na caracterização de uma mutação constitucional, haja vista o relevo pontual da realidade sobre o programa normativo, ou mesmo a evolução desta relação, já que nem as normas nem tampouco a realidade possuem um núcleo imodificável e insuscetível à influência de fatores como o tempo.

Assim, o primeiro tipo que se destaca diz respeito a influência da realidade sobre o conteúdo dos programas normativos vigentes, ou seja, existe norma e realidade disciplinada, a mudança nesses parâmetros pode representar uma mutação, desde que

Martins Fontes, 2012. ALEXY, Robert. O conceito e validade do direito. Gercélia Batista de Oliveira Mendes (Trad.). São Paulo: WMF Martins Fontes, 2009. NEVES, Marcelo. Entre Têmis e Leviatã: uma relação difícil: o Estado Democrático de Direito a partir e além de Luhmann e Habermas. São Paulo, 2006. NEVES, Marcelo. A Constitucionalização Simbólica. São Paulo: WMF Martins Fontes, 2007.

${ }^{81}$ Cf. MÜLLER, Friedrich. O Novo Paradigma do Direito: introdução à teoria e metódica estruturante. $3^{\text {a }}$ edição revista, atualizada e ampliada. São Paulo: Editora Revista dos Tribunais, 2013.

${ }^{82}$ Sobre a oposicão texto e realidade e o desenvolvimento do conceito de mutação constitucional, conferir a obra de HSU DAU-LIN (DAU-LIN, Hsü. Mutación de La Constitución. Pablo Lucas Verdú e Christian Förster (Trads). IVAP: Oñati, 1998). 
reconhecida pelo Judiciário e compatível com o direito vigente, senão se trata de pura ineficácia normativa, problema relacionado a outro campo de normatividade, ao costume, ou mesmo a outra espécie de mutação, adiante tratada, que diz respeito à obsolescência do texto constitucional.

Dito isto, passemos àquele tipo, no qual a interpretação é a grande propulsora do processo de mutação.

\subsection{Mutação constitucional a partir da interpretação inovadora e integradora}

Muitos escritores de obras literárias se sentem violentados quando roteiristas adaptam criativamente suas obras para o cinema. Neste processo criativo, aquilo que se relacionava com o mundo por meio de palavras em simples folhas de papel e aguçava a imaginação do leitor, passa por um processo de reconstrução, desta feita, para se atender à nova demanda: a demanda por imagens e por realidade. E aquilo que proporcionava dimensão singular entre autor e leitor passa a ter um intermediário, que vai direcionar o texto e a percepção não mais dos leitores, mas agora dos espectadores. Ora, tal relação, nova, parte da mesma história-texto, mas precisa se adequar ao novo auditório e contexto artístico. E esse processo de adequação não é algo traduzível, mas sim criativo, daí o sentimento de violência e reducionismo do autor em relação ao roteirista.

No direito, o processo se dá de forma similar. É impossível manter-se fiel à vontade do legislador, se é que tal vontade pode ser dimensionada. Com efeito, o processo legislativo é algo bastante complexo, sendo que a votação de um projeto de lei não pode ser dimensionado em termos particularizados. Isto é, como imaginar que cada parlamentar compartilha do mesmo sentimento interpretativo do projeto de lei em votação? Até mesmo porque o alcance dos preceitos e variações linguísticas do texto normativo é algo, a princípio insuperável, quando se quer aferir a suposta vontade do legislador.

Nesse sentido, veja-se o que se deu a respeito do conteúdo da imunidade tributária recíproca prevista no art. 150, VI, a, $\S 2^{\circ}$, da Constituição Federal, que estabelece ser vedado aos entes políticos instituir impostos sobre patrimônio, renda e serviços uns dos 
outros e estende essa imunidade a autarquias e fundações. Nota-se que o texto constitucional não faz menção expressa às empresas públicas e sociedade de economia mista. No entanto, muitas delas prestam serviços públicos exclusivos, ou seja, não competem no mercado, de modo que seria muito pernicioso tributar tais atividades, já que neste caso, a despeito de revestirem a condição de pessoas jurídicas de direito privado, atuam, a bem da verdade, como extensão das funções públicas dos respectivos entes criadores. Deste modo, aquela imunidade, a princípio restrita, foi estendida para empresas estatais como a Empresa de Correios e Telégrafos, não obstante inexistir previsão expressa na Constituição a esse respeito.

Se nos valermos de argumentos de matriz originalista ${ }^{83}$, muito possivelmente, perceberemos que a vontade do legislador constituinte não era incluir tais entes de natureza privada sob o guarda chuva da imunidade tributária, ainda que não ignorassem o fato de tais empresas, em algumas hipóteses, atuarem em regime de monopólio. O que diriam então os constituintes que votaram tal imunidade, apenas para autarquias e fundações, e a vissem estendidas para as pessoas jurídicas de direito privado integrantes da estrutura estatal? Muito provavelmente, pela similitude das atividades destas pessoas que atuam em regime de monopólio sem interferir no processo concorrencial, consentiriam os constituintes com tal hipótese. Porém, o que dizer, quando tais empresas mesclam suas atividades, acrescendo a seu portifólio, como o fez a Empresa de Correio e Telégrafos, que passou a operar também como instituição bancária?

Nesta situação, o óbvio seria caminhar no sentido de preservar a imunidade apenas para atividades sob regime de monopólio, como argumentaram cinco ministros do Supremo Tribunal Federal, em sede do julgamento do Recurso Extraordinário $n^{\circ}$ 6.013.92. Contudo, o entendimento prevalecente foi o de que, como a empresa em destaque revertia os recursos oriundos da operação enquanto instituição bancária, nas atividades postais, seria constitucional estender, e aqui, criativamente, uma imunidade, a princípio nem sequer pensada pelo constituinte originário.

Do mesmo modo se dá quanto à Lei que trata dos recursos do FGTS e autoriza, em alguns casos, que o segurado saque os recursos. Tais casos são previstos na Lei e em portaria interministerial do Poder Executivo Federal. Pois bem, será que situações similares

\footnotetext{
${ }^{83}$ A respeito do originalismo, veja-se a descrição de Ronald Dworkin (DWORKIN, Ronald. A Justiça de Toga. Jefferson Luiz Camargo (Trad). São Paulo: WMF Martins Fontes, 2010. p. 167-178).
} 
podem ser excluídas do benefício, apenas pela sua não previsão expressa, seja na Lei ou na Portaria? Cabia ao legislador ou ao membro do Poder Executivo discriminar tais situações? Existem decisões em sede de ação civil pública, que ampliam as possibilidades e estendem as hipóteses de saques para casos não incluídos na legislação e na portaria mencionada.

Ora, daí que alguns autores, reconhecendo que o processo interpretativo do direito envolve sempre criação, consideram que há, ainda que implicitamente, certa cumplicidade, um acordo tácito do legislador e do juiz. Deveras, pois o primeiro assente em relação à complementação de seu mister efetuada pelo segundo, seja se mantendo inerte, ao não modificar a lei, quando podia fazê-lo, seja aquiescendo com a jurisprudência dominante e, em reforço, propondo novas leis, que estendam aqueles entendimentos jurisprudenciais a todos quantos se sujeitam a sua autoridade. Assim, já que o monopólio da produção legislativa cabe aos parlamentos, é possível que estes modifiquem a jurisprudência mediante a introdução de uma nova legislação capaz de superar aquele entendimento judicial vigente, e/ou ao não assim proceder, estabeleçam uma relação de compadrio com o conteúdo da decisão judicial, tal qual o faz o parlamento brasileiro em relação à imunidade tributária conferida à Empresa de Correios e Telégrafos.

Interpretar, naturalmente, como se dá no cinema, significa criar, senão não se falaria em interpretação, mas sim em pura tradução. E o direito não se presta a esse papel de tradutor linguístico e gramatical de textos legislativos. Ao contrário, ele integra um processo que em confronto com a realidade, com a passagem do tempo, com a percepção do intérprete, influencia as decisões e leituras que se faz desta estrutura social.

Esse raciocínio conjuga-se fundamentalmente a uma observação realizada por Peter Häberle ${ }^{84}$, segundo a qual não existiria norma jurídica independente, senão norma jurídica interpretada. Conforme Häberle, interpretar um ato normativo nada mais é do que situá-lo no tempo ou mesmo integrá-lo à realidade pública. Tal concepção permite a Häberle afirmar, em sentido amplo, como destacou o Ministro Gilmar Mendes em seu voto na ADI 4.277 que,

\footnotetext{
${ }^{84}$ HÄBERLE, Peter. Zeit und Verfassung. IN: Probleme der Verfassungsinterpretation, org: Dreier, Ralf/Schwegmann, Friedrich, Nomos, Baden-Baden, 1976, p. 312-313..
} 
Toda lei interpretada - não apenas as chamadas leis temporárias - é uma lei com duração temporal limitada (In einem weiteren Sinne sind alle interpretierten - Gesetzen "Zeitgesetze" - nicht nur die zeitlich befristeten). Em outras palavras, o texto, confrontado com novas experiências, transforma-se necessariamente em um outro. Daí afirmar Häberle; 'O Direito Constitucional vive, prima facie, uma problemática temporal. De um lado, a dificuldade de alteração e a conseqüente duração e continuidade, confiabilidade e segurança; de outro, o tempo envolve agora mesmo, especificamente o Direito Constitucional. É que o processo de reforma constitucional deverá ser feito de forma flexível e a partir de uma interpretação constitucional aberta. A continuidade da Constituição somente será possível se passado e futuro estiverem nela associados.'

Contudo, nota-se que existe uma tensão sobressalente a essa percepção, que diz respeito ao limite da interpretação jurídica, bem como a legitimidade e aceitação de seu conteúdo pelos destinatários da norma, pois norma interpretada não pode ser o único substrato a que chamaremos direito, haja vista ser apenas o objeto final de uma cadeia e não o objeto em si ${ }^{85}$, representativo do fenômeno direito, daí a necessidade de parâmetros a essa atividade de interpretação.

Alguns preferem o argumento dito originalista que prima, a grosso modo, pela supervalorização da mítica vontade do legislador, enquanto que outros, optam por, sem negar o ponto de partida posto nos textos normativos, extrair a norma analisando não o contexto da época de aprovação da lei, mas sim o atual. Tal postura traria concretude ao direito, proporcionando maior diálogo entre os novos trajes históricos culturais ${ }^{86}$, tornando os limites da interpretação mais voláteis.

\footnotetext{
85 Aqui, sublinha-se novamente que o presente trabalho vale-se da premissa positivista quanto ao reconhecimento do que seja direito, de tal modo que a norma jurídica, ainda que não interpretada, mas posta pelas autoridades competentes, é também, nesse sentido, direito.

${ }^{86}$ Quanto ao aspecto temporal, alerta Ronald Dworkin "tais declarações são parte da história política de uma comunidade, e a história política aparece em sua melhor luz quando as leis e [podemos acrescentar] as constituições são interpretadas de modo a se ajustarem às declarações formais de propósitos e convicção. Mas também observamos o quanto esse argumento é sensível ao tempo. Não poderia ser mais frágil do que é no presente contexto, quando as declarações foram feitas não apenas em circunstâncias políticas diversas, mas por e para uma forma de vida política totalmente diferente. Seria tolice considerar as opiniões dos que votaram a Décima Quarta Emenda como um reflexo da moral pública dos Estados Unidos um século depois, quando a questão racial sofreu modificações em quase todos os aspectos. Seria também perverso; negaria à comunidade o
} 
Ora, a Constituição, por sua vez, dado seu conteúdo e normas de caráter aberto, há de se submeter a um preenchimento valorativo de seus objetivos e normatividade ${ }^{87}$, sendo esse preenchimento produzido por todos os Poderes do Estado, seja o Executivo, seja o Judiciário, seja o Legislativo.

Desta forma, os princípios de interpretação da Constituição diferem um pouco dos elementos de interpretação geral do direito ${ }^{88}$. Enquanto alguns estudiosos debatem sobre o alcance dos elementos gramatical, histórico, lógico e tantos outros, no universo constitucional, ganham valor, métodos ou princípios de outra ordem, consagrados, inclusive pela doutrina alemã de Konrad Hesse, a saber: unidade da Constituição; concordância prática; conformidade funcional; efeito integrador e força normativa da Constituição ${ }^{89}$.

Nesse prisma, cumpre afirmar que a interpretação constitucional, em razão de seu objeto, afasta-se do modelo tradicional a ser empreendido sobre os demais ramos do direito, como o direito penal, tributário e etc. Veja que diante da excepcionalidade do objeto e de sua carga valorativa e política, seu próprio conteúdo em si, passa alguma fluidez, característica essa responsável pela abertura das decisões. Neste sentido, nem sempre, é

poder de mudar seu senso público de finalidade, o que significa negar que ela possa ter quaisquer finalidades públicas". (DWORKIN, Ronald. O Império do Direito. Jefferson Luiz Camargo (Trad.). $2^{\mathrm{a}}$ ed. São Paulo: Martins Fontes, 2007. p. 437).

\footnotetext{
${ }^{87}$ Inocêncio Mártires Coelho ensina a diferença de interpretação entre Lei e Constituição, conforme excerto que se segue: "Enquanto a lei ostenta um grau relativamente alto de determinação material e de precisão de sentido, podendo, por isso, ser diretamente aplicável por qualquer operador do direito, já a Constituição - pela sua natureza, estrutura e finalidade-, apresenta-se como um sistema aberto de regras e de princípios, os quais, em razão mesmo dessa abertura e indeterminação, necessitam da mediação de agentes qualificados, como os legisladores e os juízes, sem cujo trabalho exegético, em cada caso concreto, não se opera a sua transformação de disposição em norma e, assim, a sua passagem da condição de normatividade potencial à de normatividade efetiva. Em resumo, num caso como no outro, é sempre necessária essa mediação para que as disposições constantes dos documentos normativos venham a se tornar normas, variando a criatividade ou a liberdade do intérprete em função da latitude semântica dos enunciados, maior na linguagem da Constituição, menor no fraseado das leis". (COELHO, Inocêncio Mártires. Interpretação Constitucional. $4^{\mathrm{a}}$ ed. São Paulo: Saraiva, 2011. p. 30).

${ }^{88}$ Cf. SILVA, Virgílio Afonso da. Interpretação Constitucional e Sincretismo Metodológico. (org.). Interpretação Constitucional. São Paulo: Malheiros, 2007.

${ }^{89}$ Idem, ibidem. p. 117.
} 
possível, a partir de conceitos extremamente abertos, reconduzir a decisão ao direito posto 90 e 91

Contudo, interpretar a Constituição, ainda que diante de toda as suas especificidades, não é o mesmo que promover uma mutação constitucional, mas esta pode se dá a partir daquela. Isto é, a partir de uma interpretação inovadora da Constituição que transborde a tradição, o sentido literal do preceito, associando a decisão a novos contornos da realidade, fugindo aos parâmetros contidos na interpretação ordinária da Constituição, acima definida, como são exemplos a mudança de interpretação quanto ao denominado foro por prerrogativa de função e a modificação de entendimento quanto à possibilidade de progressão de regime no caso de condenações decorrentes da prática de crimes enquadrados como hediondos ${ }^{92}$.

Em suma, a mutação constitucional pela via interpretativa se dá justamente quando há mudança de "sentido da norma, em contraste com entendimento preexistente" 93 , ou seja, "quando se estiver diante de uma alteração de uma interpretação previamente dada"94.

\footnotetext{
${ }^{90}$ FERRAZ, Anna Cândida da Cunha. Mutação, Reforma e Revisão de Normas Constitucionais. Revista dos Tribunais, ano 2, n. 5, p. 17, out/dez. 1993. Cadernos de Direito Constitucional e Ciência Política. p. 19.

91 “A dogmática prepara, pois, a decisão, cria para ela condições razoáveis, de tal modo que ela não apareça como puro arbítrio, mas decorra de argumentos plausíveis. O jurista, assim, capta o direito num procedimento de incidência, ou seja, na imputação de normas a situações sociais atuais ou potencialmente conflitivas. Entre a norma e a situação mediata. Este conjunto - normas, procedimento, situação - compõe o fenômeno da aplicação. Aplica-se o direito, por um procedimento, à realidade social. O fenômeno da aplicação exige do jurista, inicialmente, uma identificação do que seja o direito a ser aplicado. Dessa identificação se ocupa, primariamente, o pensamento dogmático. Sujeito ao princípio da inegabilidade dos pontos de partida, o pensar dogmático tem, portanto, de identificar suas premissas. Como vimos, o direito aplicável, embora seja para o jurista um dado, algo estabelecido (pelo legislador, pelas partes que contratam, pela decisão da administração) que não pode ser trocado ou substituído, tem contudo de se explicitado.”(grifo nosso) (FERRAZ JÚNIOR, Tércio Sampaio. Introdução ao Estudo do Direito: técnica, decisão, dominação. $4^{\mathrm{a}}$ ed. São Paulo: Atlas, 2003. p. 93-4).

92 Tais casos serão esmiuçados à frente, na segunda parte, quando se dedicará um capítulo ao estudo das decisões do STF, no qual a mutação se tornou um fundamento relevante para a decisão.
}

${ }^{93}$ BARROSO, Luís Roberto. Mutação Constitucional. In GONÇALVES JÚNIOR, Jerson Carneiro; BETTINI, Lúcia Elena Polletti; MOREIRA, Eduardo Ribeiro (orgs). Hermenêutica Constitucional - homenagem aos 22 anos do Grupo de Estudo Maria Garcia. Florianópolis: Conceito Editorial, 2010. p. 434.

${ }^{94}$ Idem 


\subsection{A mutação constitucional a partir da obsolescência da norma constitucional}

A Constituição, sobretudo as constituições analíticas, como a brasileira, caracterizadas pela extensão de seus preceitos e amplitude de seu alcance e ainda as Constituições reinantes em Estados sociais democráticos que valorizam direitos sociais e conferem ao Poder Público um papel central no desenvolvimento da sociedade, invariavelmente possuem muitos preceitos de ordem programática. São cartas de intenções, programas a serem perseguidos, que com status constitucional alçam força política normativa diferenciada, sobretudo quanto a sua exigibilidade ${ }^{95}$.

Pois bem, a falência da capacidade financeira do Estado e o alto endividamento estatal tem levado o Poder Público a rever essas promessas. Decerto, o Estado Social garantidor de um bem-estar ideal a todos quantos neles vivam é uma promessa utópica irrealizável e precisa ser redimensionada e racionalizada de acordo com as possibilidades econômicas, sobretudo de cada comunidade política ${ }^{96}$.

De outro lado, o extremo detalhamento de preceitos e regras constitucionais, tem levado ao engessamento de muitos procedimentos e processos, tornando algumas regras constitucionais extremamente rígidas, quando o desejável seria uma maior capacidade de ação, ou melhor, de alteração.

Nesse sentido, veja-se o prescrito pelo artigo 103, parágrafo $3^{\circ}$ da Constituição Federal que impõe ao Advogado Geral da União a defesa do ato impugnado no Controle Abstrato de Constitucionalidade, sem qualquer ressalva quanto a, por exemplo, uma posição pacífica do STF a respeito do tema, que dispensaria a autoridade do munus no caso, evitando um constrangimento do AGU em defender algo que não faz qualquer sentido ao entendimento firmado por aquela corte.

\footnotetext{
${ }^{95}$ Cf. ABRAMOVICH, Victor; COURTIS, Christian. Los Derechos sociales como derechos exigibles. Madrid: Editorial Trotta, 2002.

${ }^{96}$ SILVA, Virgílio Afonso da. O Judiciário e as políticas públicas. In PEREIRA DE SOUZA NETO; SARMENTO, Daniel (coords). Direitos Sociais: fundamentação, judicialização e direitos sociais em espécie. , Rio de Janeiro: Lumen Juris, 2008. RAMOS, Elival da Silva. Controle Jurisdicional de Politicas Públicas. São Paulo: Revista da Faculdade de Direito, 2007. p. 327-356.
} 
Assim, o tipo ora descrito, relativo à obsolescência do preceito constitucional que transmuda em uma mutação, dá-se quando se configura uma impossibilidade de executar as faculdades, os direitos e as regras estatuídas constitucionalmente.

Trata-se da desconexão entre preceito normativo e possibilidade jurídica de sua verificação. Aproxima-se um tanto das normas constitucionais simbólicas que nos fala Marcelo Neves, algo como uma legislação álibi ${ }^{97}$, na qual as suas promessas não se cumprem, pois inexiste condições para sua efetivação, ou as condições não proporcionam mais a sua execução, como no caso da atividade do AGU no controle abstrato de constitucionalidade acima resumido e adiante, na segunda parte, melhor discutido.

É o caso, mutatis mutandis, também, por exemplo, da Lei de Imprensa, apesar de se tratar da invalidação de uma Lei e não propriamente da alteração de um preceito constitucional. É que tanto num caso como noutro, há e houve alteração de um conteúdo normativo pela ultrapassagem do tempo, obsolescência de seus preceitos, reconhecido pelo Poder Judiciário.

Portanto, neste terceiro tipo de mutação, a característica que se sobressai é justamente a mudança de um conteúdo pela impossibilidade de se exercer o direito estatuído constitucionalmente, aproximando-se da ineficácia, mas com essa não se confundindo, haja vista que mutação pressupõe mudança, enquanto a ineficácia se satisfaz apenas com a não aplicabilidade do preceito constitucional.

\subsection{A mutação constitucional a partir da alteração inconstitucional da normatividade de um preceito}

A mutação constitucional, apesar de sua construção doutrinária, tem encontrado respaldo no conceito atual de Constituição, sobretudo pela necessidade desta se adaptar ao contexto imposto pela modernidade.

\footnotetext{
${ }^{97}$ NEVES, Marcelo. Constituição Simbólica. São Paulo: WMF Martins Fontes, 2011.
} 
Só que a mutação pode se mostrar contrária à Constituição, representando, portanto, uma inconstitucionalidade. Nesse caso, a rigor, não se poderia nem falar em mutação constitucional, pois este conceito pressupõe adequação aos parâmetros da Constituição. Contudo, por um imperativo investigativo, faz-se necessário reconhecer que algumas mudanças, ainda que promovidas pelo Judiciário, podem ser dotadas de tal característica.

Cabe observar que essa modalidade é a de mais difícil caracterização, sobretudo se tivermos em mente as premissas do realismo jurídico. Com efeito, posto que neste quarto e último tipo apontado não basta pontuar características singulares, como acima relacionado, já que aqui, argumentos como a autoridade dos ministros do Supremo Tribunal Federal vem à tona.

Decerto, pois a despeito de se mostrar possível, valendo-se de um método científico seguro, descrever certas inconstitucionalidades quanto a determinados entendimentos, é sabido que tais apontamentos não possuem a força da autoridade de uma corte constitucional. De modo que, tal qual se vê hoje no STF, talvez seja uma tarefa hercúlea estabelecer quando uma mutação se mostrará inconstitucional ${ }^{98}$ e ainda mais difícil quando o Legislativo ao identificar um avanço inconsistente realizado pelo STF, nada fizer a respeito.

Contudo, a despeito da falta de autoridade para descrever uma possível mutação inconstitucional, uma vez que a última palavra sempre será de fato das instituições constituídas, a depender de circunstâncias especiais, dos Tribunais ou do parlamento, alguns parâmetros tradicionais apontarão as inconstitucionalidades na hipótese, cuja ênfase se deterá no texto normativo e nos princípios jurídicos ${ }^{99}$. O texto e os princípios pela oposição de sentido entre mutação e Constituição, associados ainda, decerto, às espécies ordinárias de inconstitucionalidade, a saber: a formal, a material, a orgânica e a finalística ${ }^{100}$.

\footnotetext{
${ }^{98}$ É que os ministros parecem não estar muitos preocupados com a coerência e consistência científica de seus julgados e votos, nem tampouco se estão mudando a Constituição, ou simplesmente a interpretando, se é que tais situações podem, a rigor, serem separadas de forma estrita.

${ }^{99}$ Cumpre pontuar que, ultimamente, até parâmetros implícitos passam a compor a moldura para o reconhecimento de inconstitucionalidades, o que, a princípio, precisa ficar bem restrito, e não como se está a fazer com relação ao reconhecimento de inconstitucionalidade no financiamento de campanhas políticas por pessoas jurídicas, também melhor destrinchado adiante.
}

${ }^{100}$ RAMOS, Elival da Silva. Controle de Constitucionalidade no Brasil: perspectivas de evolução. São Paulo, Saraiva, 2010. p. 49. 
Pois bem, a mutação constitucional não é uma categoria teórica com definição e marco positivo. No entanto, como visto e melhor detalhado a frente, ainda que a Constituição não se refira expressamente a esse conceito, é fato que suas características estão presentes em várias decisões de natureza constitucional. E como tal, é possível que tais decisões, contrariamente a um raciocínio da doutrina realista, mostrem-se inconstitucionais.

Ora, trata-se de uma novidade, pois, ordinariamente, ao Judiciário não é dado produzir inconstitucionalidades, ao contrário, cabe-lhe identificar e invalidar tais situações. Ocorre que o controle de sua atividade por outros poderes é extremamente tênue e caso uma decisão do STF permita ou promova uma inconstitucionalidade, os instrumentos disponíveis para sua invalidação total são praticamente inexistentes, perante a ordem posta. Isto é, uma decisão judicial que reconheça ou produza uma mutação apenas pode ser superada por uma decisão política, mas não necessariamente pelo fato da mesma se mostrar inconstitucional.

Assim, uma mutação inconstitucional adquire validade em razão da autoridade da decisão judicial que a promove. Entretanto, esse novel conteúdo normativo só pode ser superado a partir de uma emenda constitucional formal, que em nada se aproxima do reconhecimento de uma inconstitucionalidade tal qual é realizado pelo Judiciário em sua atividade natural, notadamente quanto ao alcance dos efeitos da possível invalidação.

Exemplificando, o Supremo Tribunal Federal determinou em específico período eleitoral a verticalização das eleições, ou seja, decidiu que os partidos coligados em âmbito nacional deveriam repetir esse escopo programático de alianças nas eleições de outras esferas regionais. Tratou-se de uma inovação. Com efeito, até então nenhuma legislação ou parâmetro constitucional explícito demonstravam uma tendência clara a esse respeito. A bem da verdade, isso representou a permeabilização de um conteúdo pelo Judiciário, sem qualquer maior respaldo institucional, senão doutrinário e acadêmico.

Bem, nesse caso, o Congresso ao não concordar com esse entendimento apressou-se em aprovar uma emenda à Constituição que superava expressamente este estado de coisas, demonstrando que a mudança decorrente da interpretação inovadora dos fatos, em nada estava compreendida no sentimento constitucional vigente. E ao assim proceder mudou, ou melhor, expôs expressamente qual o sistema eleitoral desejado pelos representantes diretos do povo. 
Ora, nesse caso as eleições que se realizaram sob a égide das novas disposições promovidas pelo STF, ou seja, sob o domínio da verticalização não puderam ser invalidadas, pois a emenda constitucional a princípio não possui esse poder, já que tal poder-dever é exclusivo do Poder Judiciário. Isso demonstra que uma mudança inconstitucional informal da Constituição pode se impor pela simples autoridade do Supremo e ainda produzir efeitos que se solidificarão a despeito da mudança legislativa posterior. Tal situação limite é um problema que se precisa enfrentar, afinal as consequências podem ser incalculáveis.

Em arremate, a partir destas quatro espécies de mutação, intui-se que perceber e institucionalizar tal instituto nem sempre é tarefa fácil e segura, afinal, assim como qualquer legislação, nem sempre haverá consenso acerca da efetiva mutação constitucional, ou seja, as pessoas continuarão a discordar sobre se efetivamente o novo contorno surgido representa de fato uma realidade, o conteúdo de uma norma, uma tradição jurisprudencial, ou se o preceito tornou-se obsoleto.

Contudo, essas definições contribuem para o conhecimento do instituto, desta categoria teórica e para a transparência e legitimidade dessa construção, à medida que a partir disto pode-se cobrar mais legitimidade e colmatar limites para estes tipos de mudança da Constituição, seja concorde com seu conteúdo, ou não.

De toda forma, avança-se para analisar os casos representativos de nossa jurisprudência pátria ${ }^{101}$ acerca da mutação constitucional. O STF não costuma se valer

\footnotetext{
${ }^{101}$ No entanto, aqui, reproduzimos advertência mencionada pelo Professor Virgílio Afonso da Silva sobre o papel da jurisprudência em trabalhos como o presente: "No Brasil, com raríssimas exceções, nunca houve uma tradição entre os trabalhos acadêmicos, de utilizar a jurisprudência como material de trabalho. Quando muito algumas decisões são citadas como forma de argumento de autoridade, mas dificilmente se vê em trabalhos acadêmicos uma pesquisa extensiva na jurisprudência de determinado tribunal. Há diversas explicações possíveis para esse fenômeno: (1) No Brasil há uma crença - baseada na dicotomia entre as famílias da Commom Law e do direito codificado continental europeu - segundo o qual os precedentes judiciais têm valor apenas para a primeira, mas não para a segunda; (2) dentre outras, essa é uma das razões pelas quais a tradição jurídica brasileira é baseada sobretudo na doutrina; (3) isso pode ser percebido até mesmo nas decisões judiciais, que, em inúmeros casos, baseiam seus argumentos quase que exclusivamente na doutrina, e não em seus próprios precedentes; (4) no Brasil, especialmente no âmbito do STF, a despeito das melhoras constantes ocorridas nos últimos anos, o acesso à informação é extremamente complicado e restrito, em muitos casos, às informações constantes das ementas dos acórdãos ou a algumas palavras-chaves; (5) os Tribunais brasileiros, sobretudo o STF, julgam uma quantidade enorme de ações, o que dificulta ainda mais o acesso à informação." (Silva, Vigílio Afonso da. Direitos Fundamentais: conteúdo essencial, restrições e eficácia. São Paulo: Malheiros, 2009, p. 32$3)$.
} 
expressamente do termo mutação constitucional ${ }^{102}$, no entanto, conforme definição doutrinária, ora seguida, os exemplos de mutação constitucional pululam no âmbito da Corte e serão analisados a seguir.

\footnotetext{
${ }^{102}$ Com efeito, o Supremo Tribunal Federal tem sido comedido ao reconhecer o instituto expressamente nas ementas, mas não necessariamente nos votos. Assim, em apenas três julgados, os acórdãos citam expressamente o temo, não obstante, em alguns votos, ser comum que ministros defendam a existência de uma mutação constitucional. Neste sentido, o HC QO 86009/DF, no qual se reconheceu a existência de mutação constitucional na mudança da jurisprudência relativa à competência recursal contra ato de turma recursal de juizado especial, já que anteriormente o STF entendia se competente, ao passo, que hoje, entende ser a competência dos tribunais estaduais. E também o HC 91.361, no qual se reconheceu a interpretação judicial como instrumento de mutação informal da Constituição ea questão dos processos informais de mutação constitucional e o papel do Poder Judiciário: a interpretação judicial como instrumento juridicamente idôneo de mudança informal da Constituição. A legitimidade da adequação, mediante interpretação do Poder Judiciário, da própria CR, se e quando imperioso compatibilizá-la, mediante exegese atualizadora, com as novas exigências, necessidades e transformações resultantes dos processos sociais, econômicos e políticos que caracterizam, em seus múltiplos e complexos aspectos, a sociedade contemporânea, tudo, para assentar a ilegitimidade da prisão civil por dívida.
} 


\section{CAPÍTULO II - MUTAÇÃO CONSTITUCIONAL E PRECEDENTES DO SUPREMO TRIBUNAL FEDERAL}

O Supremo Tribunal Federal, como já adiantado, tem sido tímido em reconhecer que está diante de uma mutação constitucional. Poucos ministros da corte preocupam-se com este tema. Como se verá abaixo, os julgados, sobretudo aqueles relacionados a direitos fundamentais, centram-se sua decisão e votos na ampliação e confronto de conteúdos e quando muito na evolução interpretativa.

Assim, os ministros parecem não se importar com este instituto. A decisão do caso toma uma importância relevante, a ponto de subjulgar as demais questões técnicas. $\mathrm{O}$ mérito da decisão, a constitucionalidade ou não de uma lei, de uma restrição, a ampliação dos direitos fundamentais dominam a pauta e os julgadores menosprezam reconhecer ou não que houve uma mutação constitucional. Quando muito, apenas se valem de técnicas de decisão como a interpretação conforme.

A resposta a essa circunstância talvez esteja no receio de se autolegitimar, com suas decisões e funções. Afinal, a mutação constitucional se aproxima muito de um contexto ativista, pois que representa mudança e confronto com a posição do legislador. Ao passo que, a mudança, dita apenas interpretativa, parece deixar explícito que o julgador apenas está interpretando a norma, ou seja, realizando sua função ordinária.

Contudo, alguns ministros, ainda que timidamente e, sobretudo, o Ministro Gilmar Ferreira Mendes, esse de forma expressa, tem trazido o tema para debate, como se verá nos casos selecionados. No entanto, a Corte pouco discute a respeito e faz "vista grossa" da questão, e como nos julgados selecionados o Ministro não fora o relator, a exceção da Reclamação 4.335, é natural que ainda que o tema possa servir de fundamento da decisão, constando dos votos, ele não apareça nas ementas, e como tal não alcance popularidade.

Pois bem, a metódica utilizada consistiu em pesquisar julgados nos quais os ministros, mesmo que somente em votos isolados, admitiram tratar sua decisão de um ato reconhecedor de uma mutação constitucional. Uma pesquisa livre no sítio do Supremo Tribunal Federal apontará um cenário tímido quanto ao tema, como alertado acima. Com 
efeito, salvo os ministros Gilmar Mendes, Eros Roberto Grau e Ricardo Lewandoski, nenhum dos demais se preocupou em argumentar e fundamentar seus votos sobre esta plataforma, salvo quando em pauta o próprio instituto, como no caso da Reclamação Constitucional $n^{\circ}$ 4.335, que trata do alcance a ser conferido ao artigo 52, X da Constituição Federal $^{103}$.

Assim, como o tema é pouco explorado teoricamente nos julgados do STF, estabelecer um corte temporal não nos traria grande valia científica, afinal o STF, nem sequer firmou precedente sobre o conceito expresso de Mutação Constitucional, haja vista que o julgamento da Reclamação $\mathrm{n}^{0}$ 4.335, que trata expressamente da possibilidade de se reconhecer uma mutação constitucional quanto ao estabelecido no artigo 52, $\mathrm{X}$ da Constituição Federal, não chegou a seu final.

Logo, recortar um momento no tempo, inclusive para efeitos de comparação é totalmente contraproducente, primeiro, porque como alertado acima, o STF pouco debate sobre a questão e, segundo, que dada essa ausência de debate, um corte temporal poderia reduzir demasiadamente nosso campo de pesquisa e verificação.

Portanto, escolheu-se com base no conceito de mutação constitucional desenvolvido até aqui julgados representativos deste conceito teórico, que ainda que não expressamente reconhecido como tal na ementa do julgado o foram esparsamente, mas de maneira central e com conteúdo honesto, desenvolvido em votos de alguns ministros, ainda que apenas de um isoladamente.

Uma vez escolhidos tais julgados representativos, eles serão, a seguir, analisados seguindo o seguinte rito: a) identificação do caso, como nome, número do acórdão e tese (s) debatida (s); b) contextualização, isto é, introdução da discussão central, valendo-se da questão histórica legislativa, ou mesmo dos principais institutos jurídicos de discussão; c) Descrição do caso, ou seja, indicação dos principais argumentos do autor da ação ou recurso, assim como o resultado do julgamento; d) Jurisprudência correlata, quando houver, a saber, rol de decisões que se relacionam com o caso em exame, que discutam a mesma tese envolvida; e) Repercussão, isto é, desdobramentos do precedente, precedentes importantes

\footnotetext{
103 Cf. BARROS. Sérgio Resende de (2003). Constituição, artigo 52, inciso X: reversibilidade in Revista de Informação Legislativa. Ano 40, nº 158, Brasília: Senado Federal.
} 
sobre a mesma tese posteriores ao precedente estudado, desdobramentos na mídia, evolução da tese ou ações ajuizadas em razão do resultado do precedente estudado e g) questões para debate relacionadas direta ou indiretamente com o julgamento em exame, ainda que não tenham sido solucionadas no caso.

Dito isto, passemos a análise dos casos que nos chamaram a atenção na história recente do STF, associando quatro casos às quatro espécies de mutação desenvolvidas no capítulo precedente.

\subsection{Da união estável homoafetiva}

Trata-se de duas ações julgadas conjuntamente pelo Supremo Tribunal Federal, a saber a Arguição de Descumprimento de Preceito Fundamental - ADPF n ${ }^{\circ} 132-R J$, proposta pelo Governador do Rio de Janeiro, com o fito de velar pela aplicação do método analógico de integração do Direito a fim de equiparar as uniões estáveis homoafetivas às uniões igualmente estáveis que se dão entre pessoas de sexo diferente. Nesse sentido, buscou fazer incidir no caso o quanto disposto no art. 1723 do Código Civil, ou, subsidiariamente, para a hipótese de não cabimento da ADPF, o autor pugnou pelo seu recebimento como ação direta de inconstitucionalidade (ADI), de modo a imprimir interpretação "conforme a Constituição" aos incisos II e V do art. 19 e ao art. 33 do Decreto-lei n ${ }^{\circ}$ 220/75 (Estatuto dos Servidores Públicos do Estado do Rio de Janeiro) e ao art. 1.723 do Código Civil. Interpretação essa que, da mesma forma, resultasse na não-proibição do regime jurídico da união estável entre heteroafetivos às uniões de traço homoafetivo.

Já a ADI n 4.277-DF foi proposta pelo Procurador Geral da República com a finalidade de se conferir também interpretação conforme a Constituição ao art. 1.723 do Código Civil, de forma a estabelecer ser obrigatório o reconhecimento, no Brasil, da união entre pessoas do mesmo sexo, como entidade familiar, desde que atendidos os requisitos exigidos para a constituição da união estável entre homem e mulher; e b) que os mesmos direitos e deveres dos companheiros nas uniões estáveis se estendam aos companheiros nas uniões entre pessoas do mesmo sexo. Tudo Isto sob as alegações de que a obrigatoriedade do reconhecimento da união entre pessoas do mesmo sexo como entidade familiar seria extraída 
dos princípios constitucionais da dignidade da pessoa humana, da igualdade, da vedação de discriminações odiosas, da liberdade e da proteção à segurança jurídica.

Pois bem, a doutrina civilista costumava restringir as hipóteses de casamento e de união estável, tal qual, expresso literalmente no Código Civil (art. 1733) e na própria Constituição Federal (art. $226 \S 3^{\circ}$ ), a uniões de casais de sexos diferentes. O próprio Ministro Lewandowski sublinhou esta questão, quando afirmou:

Embora os juízes possam e devam valer-se das mais variadas técnicas hermenêuticas para extrair da lei o sentido que melhor se aproxime da vontade original do legislador, combinando-a com o Zeitgeist vigente à época da subsunção desta aos fatos, a interpretação jurídica não pode desbordar dos lindes objetivamente delineados nos parâmetros normativos, porquanto, como ensinavam os antigos, in claris cessat interpretatio. E, no caso sob exame, tenho que a norma constitucional, que resultou dos debates da Assembléia Constituinte, é clara ao expressar, com todas as letras, que a união estável só pode ocorrer entre o homem e a mulher, tendo em conta, ainda, a sua possível convolação em casamento.

Concluindo, afirma o ministro que tais uniões só seriam válidas se compusessem um quarto gênero familiar, ao lado do casamento, união estável e família monoparental, utilizando-se da técnica da integração.

O Judiciário, de modo geral, assim procedia, não destoando os cartórios e as instituições religiosas. Como bem anotou o Ministro Ayres Britto em seu voto, acerca do panorama das decisões sobre o tema, pelo país afora, in verbis:

Os Tribunais que se dignaram prestar informações acerca das ações em trâmite no seu espaço de jurisdição destacaram suas posições majoritárias: a) em favor da equiparação entre a união estável heterossexual e a união homoafetiva: Acre, Goiás, Rio Grande do Sul, Rio de Janeiro, Paraná (o Tribunal de Justiça do Rio Grande do Sul, por exemplo, noticiou o reconhecimento de direitos a companheiro de servidor em união homoafetiva e, desde 2004, a edição de provimento normativo com a finalidade de determinar aos serviços 
notariais o registro de documentos relacionados com uniões da espécie); b) contrário ao reconhecimento dos efeitos jurídicos da união estável à união entre parceiros do mesmo sexo: Distrito Federal e Santa Catarina. Mais: O Tribunal de Justiça da Bahia acrescentou que o Poder Judiciário, no exercício da função administrativa (aplicação do Estatuto dos Servidores), não pode conceder direitos que não estejam previstos em lei, e que a divergência nos julgamentos é de ser resolvida pela vias recursais, não se configurando a controvérsia judicial em si como ato lesivo a preceito fundamental. Entende, portanto, incabível a ADPF. Já o Tribunal de Justiça de Santa Catarina, por ele foi noticiado que as uniões homoafetivas (entendidas como "parcerias civis") são ali regidas pelo direito das obrigações (sociedades de fato), situando-se, portanto, na esfera de competência das varas cíveis comuns, e não das varas de família. A seu turno, o Tribunal do Espírito Santo defendeu que a enumeração constitucional das entidades familiares é meramente exemplificativa, pelo que nada impede o reconhecimento jurídico da união estável entre pessoas do mesmo sexo. Por fim, alguns Tribunais noticiaram a inexistência de processos que tenham por objeto o reconhecimento de efeitos jurídicos a uniões homoafetivas (Tocantins, Sergipe, Pará, Roraima).

É fato que tal circunstância tem fundamento histórico e, se considerarmos argumentos de teor originalista, a menção a pessoas de sexos diferentes assim foi realizada pelo constituinte justamente para que não houvesse reconhecimento de efeitos civis a uniões de pessoas do mesmo sexo. Nesse sentido, anotaram os Ministros Ricardo Lewandowski e Carmen Lúcia em seus respectivos votos, como trecho do voto do primeiro a seguir transcrito:

Verifico, ademais, que, nas discussões travadas na Assembléia Constituinte a questão do gênero na união estável foi amplamente debatida, quando se votou o dispositivo em tela, concluindo-se, de modo insofismável, que a união estável abrange, única e exclusivamente, pessoas de sexo distinto. Confira-se abaixo: 'O SR. CONSTITUINTE GASTONE RIGHI: - Finalmente a emenda do constituinte Roberto Augusto. É o art. 225 (sic), § 3o. Este parágrafo prevê: 'Para efeito da proteção do Estado, é reconhecida a união estável entre homem e mulher como entidade familiar, devendo a lei facilitar sua conversão em casamento' Tem-se prestado a amplos comentários jocosos, seja pela 
imprensa, seja pela televisão, com manifestação inclusive de grupos gaysés do País, porque com a ausência do artigo poder-se-ia estar entendendo que a união poderia ser feita, inclusive, entre pessoas do mesmo sexo. Isto foi divulgado, por noticiário de televisão, no showástico, nas revistas e jornais. $O$ bispo Roberto Augusto, autor deste parágrafo, teve a preocupação de deixar bem definido, e se no §o: 'Para efeito de proteção do Estado, é reconhecida a união estável entre o homem e a mulher como entidade familiar, devendo a lei facilitar sua conversão em casamento'. Claro que nunca foi outro o desiderato desta Assembléia, mas, para se evitar toda e qualquer malévola interpretação deste austero texto constitucional, recomendo a $V$. Exa. que me permitam aprovar pelo menos uma emenda. O SR. CONSTITUINTE ROBERTO FREIRE: - Isso é coação moral irresistivel. O SR. PRESIDENTE (UL YSSES GUIMARÃES): - Concedo a palavra ao relator. O SR. CONSTITUINTE GERSON PERES: - A Inglaterra já casa homem com homem há muito tempo. O SR. RELATOR (BERNARDO CABRAL): - Sr. Presidente, estou de acordo. O SR. PRESIDENTE ULYSSES GUIMARÃES): - Todos os que estiverem de cordo permaneçam como estão. (Pausa). Aprovada (Palmas)' Os constituintes, como se vê, depois de debaterem o assunto, optaram, inequivocamente, pela impossibilidade de se abrigar a relação entre pessoas do mesmo sexo no conceito jurídico de união estável'.

Todavia, a realidade social é um pouco diversa dos preceitos textuais expressos nestes dispositivos mencionados. Deveras, muitos relacionamentos amorosos possuem como base uma união homoafetiva, isto é, pessoas do mesmo sexo, agem como um casal heterossexual previsto nos artigos destacados. Para estas pessoas, não importava o que diziam os preceitos textuais, a realidade afetiva deles se contrapôs e impôs-se de per si.

Anteriormente à decisão do Supremo Tribunal Federal reconhecendo tais uniões como aptas a produzirem, por analogia, os mesmos efeitos das uniões ditas tradicionais, os demais órgãos, inclusive do Executivo e Judiciário (este de modo isolado), já vinham, por modo "transverso", reconhecendo efeitos a este tipo de união, como o reconhecimento de efeitos previdenciários, tributários (este realizado pela própria administração, para efeitos da legislação do Imposto sobre Renda) e eleitorais, nos quais já 
imputavam inelegibilidade a pessoas que possuíssem uniões homoafetivas estáveis com chefes do poder executivo.

Pois bem, vê-se, do narrado, um típico exemplo de mutação constitucional a partir do alargamento do sentido do texto, fomentando uma hipertrofia de sua abrangência de modo a alcançar novas realidades, ou seja, acresce-se à ideia de uma união heterossexual, a possibilidade de termos reconhecida uma união homossexual, a qual, inicialmente, não havia sido prevista, mas que se impôs, enquanto realidade, e como tal, necessitava de amparo constitucional-legal ${ }^{104}$. Trata-se do primeiro tipo de mutação definido no capítulo anterior.

Entretando, cumpre acentuar que o Ministro Lewandowski rechaçou este entendimento, in verbis:

Não há, aqui, penso eu, com o devido respeito pelas opiniões divergentes, como cogitar-se de uma de mutação constitucional ou mesmo de proceder-se a uma interpretação extensiva do dispositivo em foco, diante dos limites formais e materiais que a própria Lei Maior estabelece no tocante a tais procedimentos, a começar pelo que se contém no art. $60, \S 40$, III, o qual erige a "separação dos Poderes” à dignidade de 'cláusula pétrea', que sequer pode ser alterada por meio de emenda constitucional.

Contudo, em conclusão, entre o sincretismo interpretativo bastante elástico, condutor de alguns votos, sobretudo do relator, arrimado na "busca da felicidade", no

\footnotetext{
${ }^{104}$ Conforme assentou o Ministro relator Ayres Britto, a família deveria servir de norte interpretativo para as figuras jurídicas do casamento civil, da união estável, do planejamento familiar e da adoção, o relator registrou que a diretriz da formação dessa instituição seria o não-atrelamento a casais heteroafetivos ou a qualquer formalidade cartorária, celebração civil ou liturgia religiosa. Realçou que família seria, por natureza ou no plano dos fatos, vocacionalmente amorosa, parental e protetor a dos respectivos membros, constituindo-se no espaço ideal das mais duradouras, afetivas, solidárias ou espiritualizadas relações humanas de índole privada, o que a credenciaria como base da sociedade (CF, art. 226, caput ). Desse modo, anotou que se deveria extrair do sistema a proposição de que a isonomia entre casais heteroafetivos e pares homoafetivos somente ganharia plenitude de sentido se desembocasse no igual direito subjetivo à formação de uma autonomizada família, constituída, em regra, com as mesmas notas factuais da visibilidade, continuidade e durabilidade (CF, art. 226, § $3^{\circ}$ : "Para efeito da proteção do Estado, é reconhecida a união estável entre o homem e a mulher como entidade familiar, devendo a lei facilitar sua conversão em casamento"). Mencionou, ainda, as espécies de família constitucionalmente previstas (art. 226, $\S \S 1^{\circ}$ a $4^{\circ}$ ), a saber, a constituída pelo casamento e pela união estável, bem como a monoparental. Arrematou que a solução apresentada daria concreção aos princípios da dignidade da pessoa humana, da igualdade, da liberdade, da proteção das minorias, da não-discriminação e outros (informativo 625 $\mathrm{STF})$.
} 
"constitucionalismo fraternal" e na "família como princípio espiritual”, prefere-se identificar no caso, como os Ministros Luiz Fux e Gilmar Mendes ${ }^{105}$, uma espécie de mutação constitucional, pois segundo Luiz Fux, "uma mudança das relações fáticas (como no caso se evidencia) pode - ou deve - provocar mudanças na interpretação da Constituição.”

\subsection{Da progressão de regime para os crimes hediondos}

Também é digna de menção a decisão acerca da progressão de regime dos crimes hediondos ( $\mathrm{HC} \mathrm{n}^{\circ}$ 82.959). Neste julgamento, o paciente e impetrante foi acusado da prática do delito previsto no art. 214, cc. arts. 224, §1o, I, 226, III, e 71, todos do Código Penal (crimes contra a dignidade sexual). Condenado, interpôs apelação, julgada pela 1a Câmara Criminal do Tribunal de Justiça do Estado de São Paulo, que lhe deu parcial provimento para reduzir a pena a 12 anos e 3 meses de reclusão, mantido o regime integral fechado para o seu cumprimento. Em writ impetrado perante o Superior Tribunal de Justiça (HC no 23.920), argumentou o impetrante que o crime pelo qual fora condenado não poderia ser considerado hediondo, já que dele não resultara lesão corporal grave nem morte, tendo sido praticado apenas com violência presumida. Sustentou, outrossim, a inconstitucionalidade do art. 2o, $\S 1 \mathrm{o}$, da Lei no 8.072/90, que veda a progressão de regime, acrescentando, em alternativa, que tal norma teria sido revogada pela Lei $n^{\circ}$ 9.455/97 (Lei que permite a progressão para o crime de tortura, o qual também é considerado hediondo).

Historicamente, após grande comoção popular nacional acerca de um crime brutal de grande repercussão e em razão não só da crueldade, mas também da expressividade da vítima e do algoz, o parlamento votou uma lei que impunha a determinados crimes penas mais severas, passando a nominá-los crimes hediondos. Correlato a este aumento de penas,

\footnotetext{
${ }^{105}$ Conforme excerto do voto que se segue: “diante da não equivocidade, da não ambiguidade do próprio texto, pareceria muito estranha a intervenção do Tribunal para fazer essa segunda subleitura do texto, que realmente faz uma alteração substancial. Mas me curvo - como já disse também - ao argumento trazido aqui de que essa norma tem servido para fundamentar decisões no sentido negativo à pretensão formulada em juízo, com o objetivo de se reconhecer a formalização da união. Então, ela está tendo esse tipo de aplicação de forma generalizada - tanto é que, no pedido do Governador do Estado do Rio, formula-se a impugnação das próprias decisões judiciais".
} 
também se vedou a possibilidade de progressão de regime durante o cumprimento das penas (art. $2^{\circ}$ da Lei $n^{\circ} 8.072 / 90$ ), estabelecendo-se ainda que o regime imposto seria cumprido em regime inicialmente e integralmente fechado.

Ora, a lei 8.072 data de 1992, e muitos crimes e julgamentos se deram sob o manto de sua exigibilidade. Contudo, o regime de cumprimento da pena e a impossibilidade de progressão de regime, também sempre foram objeto de contestação. O Supremo Tribunal Federal, por sua vez, pacificou, sobre determinada composição, o entendimento de que tal sistemática não ofenderia qualquer preceito fundamental, declarando a sua constitucionalidade (HC $\mathrm{n}^{\text {o }}$ 69.657), in verbis:

EMENTA: HABEAS CORPUS. LEI DOS CRIMES HEDIONDOS. PENA CUMPRIDA NECESSARIAMENTE EM REGIME FECHADO. CONSTITUCIONALIDADE DO ARTIGO 2o - $\$ 1$ o DA LEI 8 072. Trafico ilícito de entorpecentes. Condenação, onde o artigo $2 o-\xi 1^{\circ}$ da Lei 8.072, dos crimes hediondos, impõe cumprimento da pena necessariamente em regime fechado. Não há inconstitucionalidade em semelhante rigor legal, visto que o princípio da individualização da pena não se ofende na impossibilidade de ser progressivo o regime de cumprimento da pena retirada a perspectiva da progressão frente a caracterização legal da hediondez, de todo modo tem o juiz como dar trato individual a fixação da pena, sobretudo no que se refere a intensidade da mesma. Habeas corpus indeferido por maioria " ('DJ ' de 8.6 93).

Contudo, em 23.2.2006, o Plenário do Supremo deferiu habeas corpus $\mathrm{n}^{\mathrm{o}}$ 82.959/SP e declarou incidenter tantum a inconstitucionalidade do $\S 1^{\circ}$ art. $2^{\circ}$ da Lei 8.072/90, e ainda, explicitou que,

A declaração incidental de inconstitucionalidade do preceito legal em questão não gerará consequências jurídicas com relação às penas já extintas nessa data, pois esta decisão plenária envolve, unicamente, o afastamento do óbice representado pela norma ora declarada inconstitucional, sem prejuízo da apreciação, caso a caso, pelo magistrado competente, dos demais requisitos pertinentes ao reconhecimento da possibilidade de progressão. 
Novamente, o Supremo modifica interpretação constitucional anterior desta feita, declarando inconstitucional norma que ele já havia declarado constitucional ${ }^{106}$, em sede de controle incidental, inaugurando mais uma espécie de mutação constitucional. Contudo, novamente, apenas o Ministro Gilmar Mendes sublinhou tal circunstância em seu voto, in verbis:

Esses casos, fica evidente que o Tribunal não poderá fingir que sempre pensara dessa forma. Daí a necessidade de, em tais casos, fazer-se o ajuste do resultado, adotando-se técnica de decisão que, tanto quanto possível, traduza a mudança de valoração. No plano constitucional, esses casos de mudança na concepção jurídica podem produzir uma mutação normativa ou a evolução na interpretação, permitindo que venha a ser reconhecida a inconstitucionalidade de situações anteriormente consideradas legítimas. A orientação doutrinária tradicional, marcada por uma alternativa rigorosa entre atos legítimos ou ilegítimos (entweder als rechtmässig oder als rechtswidrig), encontra dificuldade para identificar a consolidação de um processo de inconstitucionalização (Prozess des Verfassungswidrigwerdens) . Prefere-se admitir que, embora não tivesse sido identificada, a ilegitimidade sempre existira. (...) A evolução do entendimento doutrinário e jurisprudencial - uma autêntica mutação constitucional - passava a exigir, no entanto, que qualquer restrição a esses direitos devesse ser estabelecida mediante expressa autorização legal.

Aqui, trata-se do segundo tipo de mutação, a levada a efeito mediante o processo interpretativo de evolução jurisprudencial. Aqui, sublinha-se que não se trata de reconhecer um erro, absolutamente. Mas de avançar sobre o preenchimento do conteúdo dos

\footnotetext{
${ }^{106}$ Cumpre relatar que este tipo de situação é possível em sede de controle incidental, mas de caráter duvidoso, em sede de controle abstrato, "Nesse sentido, parte da doutrina defende a possibilidade de rediscutir as questões já definidas pelo Supremo Tribunal Federal em sede de controle abstrato de constitucionalidade, desde que seja apresentada linha argumentativa diversa da enfrentada pela Corte. Cumpre, contudo, atentar para o real significado da aludida reabertura. Será descabida se pretender esgrimir novos argumentos em prol da constitucionalidade de ato normativo já declarado inconstitucional ou na defesa da inconstitucionalidade de diploma julgado constitucional, salvo, nessa última hipótese, mediante comprovação de efetiva mudança da situação de fato. Nesse caso, a rediscussão, ainda que à luz de novos fundamentos, estará a violar a qualidade de coisa julgada oponível erga omnes da decisão, infirmando, na prática, o caráter aberto da causa petendi. (Leal, Stielfelmann Roger. O efeito vinculante na Jurisdição Constitucional. São Paulo: Saraiva, 2006, p. 173-174).
} 
direitos fundamentais, no caso o direito à liberdade. Se nos ativermos apenas ao direito como interpretação, supervalorizando o seu produto e menosprezando o papel da norma jurídica em si, pouca valia teria essa mudança jurisprudencial. É que, no caso, tratar-se-ia apenas de uma nova interpretação do direito, inovadora, decerto, mas ainda pura e simplesmente interpretação.

E talvez, seja este o debate que o Supremo Tribunal Federal, ainda não se propôs a enfrentar. Veja-se que a mutação tem um papel importante na definição da ordem jurídica, ela traz o novo, é fato. Seja por uma interpretação, seja pelo reconhecimento de uma realidade, pela obsolescência de uma norma, em todas essas hipóteses se está inovando e desbordando do puro papel interpretativo. Essa visão contrasta com o papel comedido dos tribunais, e esse debate mais qualificado tem faltado não só nos tribunais, como também na doutrina.

Nesse sentido, apenas quando o tribunal assumir esse papel de modificador da Constituição, é que se poderá avançar inclusive sobre o último tipo aqui definido de mutação, a mutação inconstitucional, pois só quando o tribunal admitir está modificando a vontade do constituinte originário e não simplesmente interpretando a norma, poder-se-á avançar sobre a constitucionalidade ou inconstitucionalidade de uma mutação constitucional, como é a opinião do trabalho sobre a Reclamação ${ }^{\circ} 4.335$, adiante tratada.

\subsection{Suspensão de ato considerado inconstitucional pelo STF mediante ato do Senado Federal (Art. 52, X da CF).}

Trata-se de uma reclamação proposta pela Defensoria Pública da União, a de $n^{\circ}$ 4.335, ajuizada contra decisões do Juiz da Vara de Execuções Penais da cidade de Rio Branco no Estado do Acre. Nas decisões, o Juiz indeferira pedido de progressão de regime em favor de condenados a penas de reclusão em regime integralmente fechado em decorrência da prática de crimes hediondos.

Pois bem, alegou-se na reclamação ofensa à autoridade da decisão da Corte no HC $n^{\circ} 82959 / S P$, de relatoria do Ministro Marco Aurélio, acima mencionado, em que restou 
declarada a inconstitucionalidade do $\S 1^{\circ}$ do art. $2^{\circ}$ da Lei $8.072 / 90$, que justamente vedava a progressão de regime aos condenados pela prática de crimes hediondos.

O relator, Ministro Gilmar Mendes, votou pela procedência da reclamação a fim de cassar as decisões impugnadas, assentando que caberia ao juízo reclamado proferir nova decisão para avaliar se, no caso concreto, os interessados atendiam ou não os requisitos de gozo do referido benefício.

Como havia discussão quanto ao cabimento da reclamação, o Ministro afirmou que a jurisprudência do STF evoluiu relativamente à utilização da reclamação em sede de controle "concentrado" de normas, concluindo pelo cabimento da reclamação para todos os que comprovassem prejuízo resultante de decisões contrárias às suas teses, em reconhecimento à eficácia vinculante erga omnes das decisões de mérito proferidas em sede de controle abstrato.

Contudo, em oposição, o juízo reclamado, em suas informações, argumentou no sentido de que a eficácia erga omnes da decisão no HC 82959/SP dependeria da expedição de resolução do Senado suspendendo a execução da lei (CF, art. 52, X), haja vista que a decisão foi prolatada em sede de controle concreto.

No voto prolatado pelo Ministro Gilmar Mendes, o mesmo defende, contudo, que a suspensão da execução pelo Senado do ato declarado inconstitucional pelo STF seria ato meramente político e que a amplitude conferida ao controle abstrato de normas e a possibilidade de se suspender, liminarmente, a eficácia de leis ou atos normativos, com eficácia geral, no contexto da $\mathrm{CF} / 88$, concorreriam para infirmar a crença na própria justificativa do instituto da suspensão da execução do ato pelo Senado, inspirado que seria numa concepção de separação de poderes que hoje supostamente estaria ultrapassada.

Nesse sentido, salientou serem inevitáveis, portanto, as reinterpretações dos institutos vinculados ao controle incidental de inconstitucionalidade, notadamente o da suspensão de execução da lei pelo Senado Federal. De tal forma que, atualmente, a fórmula relativa à suspensão de execução da lei pelo Senado haveria de ter simples efeito de publicidade. 
O Min. Eros Grau, em voto-vista, igualmente, julgou procedente a reclamação, acompanhando o voto do relator, no sentido de que, pelo art. 52, X, da CF, ao Senado Federal, no quadro de uma verdadeira mutação constitucional, está atribuída competência apenas para dar publicidade à suspensão da execução de lei declarada inconstitucional, no todo ou em parte, por decisão definitiva do Supremo Tribunal Federal, haja vista que essa decisão contém força normativa bastante para suspender a execução da lei.

A divergência no caso foi inaugurada pelo Ministro Sepúlveda Pertence, o qual asseverou que não se poderia reduzir-se o papel do Senado, haja vista que com a prevalência do controle "concentrado", o mecanismo de outorga ao Senado da competência para a suspensão da execução da lei tem se tornado cada vez mais obsoleto. Assim, afirmou que combatê-lo, por meio do que chamou de 'projeto de decreto de mutação constitucional', já não seria mais necessário, já que a Emenda Constitucional no 45/2004 dotou o Supremo de um poder que, praticamente, sem reduzir o Senado a um órgão de publicidade de suas decisões, dispensaria essa intervenção, qual seja, o instituto da súmula vinculante $(\mathrm{CF}$, art. 103-A).

Por sua vez, o Min. Joaquim Barbosa votou pela manutenção da leitura tradicional do art. 52, X, da CF, pois ainda que se aceitasse a tese da mutação, seriam necessários dois fatores adicionais não presentes: o decurso de um espaço de tempo maior para verificação da mutação e o conseqüente e definitivo desuso do dispositivo.

Bem, como visto, em síntese, trata-se de saber se a decisão proferida no HC 82.959, no que concerne ao art. 2o, § 1o, da Lei 8.072/1990, é dotada de eficácia erga omnes, independente ou não do cumprimento do disposto no art. 52, X, da Constituição da República, que confere ao Senado a competência privativa para "suspender a execução, no todo ou em parte, de lei declarada inconstitucional por decisão definitiva do Supremo Tribunal Federal”.

Explicando o problema, menciona o Ministro Lewandowski, em seu voto, que as decisões em controle concreto ensejavam a possibilidade de soluções distintas para casos semelhantes, razão pela qual, com o objetivo de se atenuar o problema, houve por bem o constituinte de 1934, "atribuir competência ao Senado Federal para suspender a execução, no todo ou em parte, de qualquer lei ou ato, deliberação ou regulamento declarados inconstitucionais pelo Judiciário (arts. 91, IV, e 96)". 
Ora, conforme restou consignado no voto do Ministro Joaquim Barbosa, não se trata de um desuso do instituto, pois no período de aproximadamente 10 anos, quase 100 normas declaradas inconstitucionais pelo Supremo Tribunal Federal tiveram sua eficácia suspensa pelo Senado.

Demais disso, como bem pontuou o Ministro Sepúlveda Pertence, a criação de outros institutos mitigou o prejuízo de soluções distintas para casos semelhantes, assim como acelerou o juízo político do Senado. A bem da verdade, substituiu-o por outros instrumentos de caráter judicial, como a súmula vinculante e a repercussão geral.

Nestes termos, uma mutação nestas circunstâncias se mostra manifestamente inconstitucional, já que não satisfaz quaisquer dos requisitos necessários, tais como realidade diversa, possibilidade aberta do sentido semântico da norma e/ou obsolescência da regra a ser modificada.

O raciocínio aqui desenvolvido encontra guarida no voto do Ministro Lewandowski ${ }^{107}$ quanto à aplicabilidade do artigo 52, X da Constituição. Apesar do fundamento diverso utilizado pelo ministro, mas se observando a regra literal emanada do texto e devido a sua natureza já delimitar, a interpretação possível e a semântica natural, importando aqui, excepcionalmente, na admissão de uma única resposta correta, percebe-se que no caso, a sua não aplicação, segundo os votos dos Ministros Gilmar Mendes e Eros Grau, só pode se dar em sede de decisão conforme com redução de texto, mas nunca em sede de mutação, pois esta, para existir, pressupõe uma interpretação, uma prática anterior, capaz de ser mudada e, acima de tudo, coerente com a prescrição normativa analisada, o que no caso não se evidencia.

Assim, não se pode diminuir o papel do Senado pois tal providência instaurará uma oposição central aos limites normativos do texto, a ponto de invalidá-lo por vias não formais de mudança, e mais, inconstitucionais, segundo o modelo aqui proposto.

Logo, "a exegese proposta vulnera o próprio sistema de separação de poderes”, tal qual afirmou o Ministro Lewandowski, pois em suas palavras, "a estrutura semântica do

\footnotetext{
${ }^{107}$ Reclamação Constitucional no ${ }^{\circ} 4.335$.
} 
inc. $\mathrm{X}$ do art. 52 sugere tratar-se de um dispositivo constitucional de eficácia plena e aplicabilidade imediata, que não comporta grandes manobras exegéticas por parte de seus intérpretes".

Portanto, uma mutação assim operada, além de se mostrar uma mudança da Constituição por quem não está legitimado para tanto, ou seja, além de representar uma inconstitucionalidade formal, por vício de iniciativa, igualmente representa uma inconstitucionalidade material, pois a regra em destaque convive harmonicamente, no âmbito do sistema de controle de constitucionalidade com outros dispositivos, os quais acaso não fossem suficientes ao desiderato do constituinte, já teriam sido alterados.

Em suma, a despeito do julgamento ainda não haver chegado a seu final, pois houve pedido de vista do Ministro Teoria Zavaski, a possibilidade de se caracterizar no caso uma mutação se opõe frontalmente às hipóteses teóricas desenvolvidas no presente trabalho, pois, no caso, não se encontram, como acima expostos, os requisitos necessários para alteração do alcance normativo do preceito em tela.

\subsection{Da prisão civil por dívida}

Outra espécie de mutação que merece destaque é a possibilidade da prisão civil por dívidas do depositário infiel. Se formos nos ater ao texto normativo da Constituição, bem como a anos de prática constitucional, o infiel depositário sempre se sujeitou à prisão civil ${ }^{108}$.

Entretanto, após o julgamento do RE 349.703, essa realidade foi sensivelmente modificada, de tal modo que, hoje, não existe mais a possibilidade de prisão por dívida fora da hipótese do não pagamento de pensão alimentícia (veja-se também RE 466.343 e HC 87.585).

\section{Segundo o Ministro Gilmar Ferreira Mendes ${ }^{109}$,}

\footnotetext{
${ }^{108}$ Conforme jurisprudência pacífica do Supremo Tribunal Federal.

${ }^{109}$ MENDES, Gilmar Ferreira. Jurisdição Constitucional- 2002 -2010. São Paulo: Saraiva, 2012.
} 
Desde que o Brasil aderiu, sem qualquer reserva, ao Pacto Internacional dos Direitos Civis e Políticos (art. 11) e à Convenção Americana sobre Direitos Humanos - Pacto de San Jose da Costa Rica (art. $7^{\circ}, 7$ ), - ambos do ano de 1992, não existe suporte, no ordenamento jurídico infraconstitucional brasileiro, para a prisão civil do depositário infiel. É preciso notar que a natureza específica e especial desses diplomas internacionais coloca-os acima do ordenamento infraconstitucional nacional, tornando inaplicável a legislação com ele incompatível. A partir desse raciocínio, não mais subsistem, pois, o Decreto-lei n. 911/69 e o art. 652 do Novo Código Civil (Lei n. 10.406/2002). (...) o Tribunal assentou que o caráter especial desses diplomas internacionais sobre direitos humanos reserva-lhes lugar específico no ordenamento jurídico, estando abaixo da Constituição, porém acima da legislação interna. O status normativo de supralegalidade dos tratados internacionais de direitos humanos subscritos pelo Brasil torna inaplicável a legislação infraconstitucional com ele conflitante.

Pois bem, conforme se verifica dos votos dos Ministros Moreira Alves e Sidney Sanches, a jurisprudência do tribunal era pacífica ao reconhecer a legitimidade da prisão civil no caso do depositário infiel ${ }^{110}$, no entanto, em razão de nova conformação quanto à interpretação do status dos tratados internacionais de direitos humanos, essa jurisprudência mudou radicalmente, como visto acima, trazendo-nos, mais um exemplo de mutação constitucional, desta feita pela modificação da interpretação constitucional anterior e a imposição de novo sentido ao teor normativo, atendendo à evolução da realidade constitucional e aos pactos internacionais pertinentes aos direitos humanos, dos quais o Brasil seja parte.

\footnotetext{
${ }^{110}$ Destaque-se acórdão de 1996 do STF, “A Constituição proíbe a prisão civil por dívida, mas não a do depositário que se furta à entrega de bem sobre o qual tem a posse imediata, seja o depósito voluntário ou legal (art. $5^{\circ}$, LXVII). 2- Os arts. $1^{\circ}$ (art. 66 da Lei ${ }^{\circ} 4.728 / 65$ ) e $4^{\circ}$ do Decreto-lei ${ }^{\circ} 911 / 69$, definem o devedor alienante fiduciário como depositário, porque o domínio e a posse direta do bem continuam em poder do proprietário fiduciário ou credor, em face da natureza do contrato. 3- A prisão de quem foi declarado, por decisão judicial, como depositário infiel é constitucional, seja quanto ao depósito regulamentado no Código Civil como no caso de alienação protegida pela cláusula fiduciária. 4- Os compromissos assumidos pelo Brasil em tratado internacional de que seja parte ( $\S 2^{\circ}$ do art. $5^{\circ}$ da Constituição) não minimizam o conceito de soberania do Estado-povo na elaboração da sua Constituição; por esta razão, o art. $7^{\circ}, \mathrm{n}^{\circ} 7$, do Pacto de São José da Costa Rica, ("ninguém deve ser detido por dívida": "este princípio não limita os mandados de autoridade judiciária competente expedidos em virtude de inadimplemento de obrigação alimentar") deve ser interpretado com as limitações impostas pelo art. $5^{\circ}$, LXVII, da Constituição. 5- "Habeas-corpus" conhecido em parte e, nesta parte, indeferido". (HC 73.044-2/SP).
} 
No $\mathrm{RE} \mathrm{n}^{\circ} 466.343-1 / \mathrm{SP}$, no qual igualmente se discutia a compatibilidade ou não, de certa leitura do art. 4o do Decreto-Lei n ${ }^{\circ}$ 911, de 1o de outubro de 1969, agora com a redação introduzida pela Lei no 6.071, de 3 de julho de 1974 - que concede ao credor fiduciário ação de depósito fundada no contrato de alienação fiduciária em garantia, quando não encontre o bem ou não se ache este na posse do devedor fiduciante - com a norma do art. 153, § 17, da Emenda Constitucional no 1, de 1969, que vedava a prisão civil por dívida, multa ou custas, salvo o caso de depositário infiel ou do responsável pelo inadimplemento de obrigação alimentar, na forma da lei, destacou o Ministro Gilmar Mendes sobre o tema, sublinhando uma hipótese de mutação,

Deixo acentuado, também, que a evolução jurisprudencial sempre foi uma marca de qualquer jurisdição de perfil constitucional. A afirmação da mutação constitucional não implica o reconhecimento, por parte da Corte, de erro ou equívoco interpretativo do texto constitucional em julgados pretéritos. Ela reconhece e reafirma, ao contrário, a necessidade da continua e paulatina adaptação dos sentidos possíveis da letra da Constituição aos câmbios observados numa sociedade que, como a atual, está marcada pela complexidade e pelo pluralismo.

Daí se vê mais um exemplo de preenchimento do instituto pela interpretação mudando seu conteúdo e teor da jurisprudência, típico exemplo do segundo tipo de mutação.

\subsection{Defesa da constitucionalidade do ato pelo Advogado Geral da União}

Por fim, traz-se um exemplo de uma mutação reconhecida em razão da obsolescência de texto normativo constitucional, dada a inoperância integral de preceito normativo.

Bem, trata-se da interpretação a ser conferida sobre o alcance do preceito incerto no art. 103, parágrafo $3^{\circ}$, da Constituição Federal, que atribui ao Advogado Geral da União o dever de defender a lei ou ato normativo atacado em sede de Ação Direta de Inconstitucionalidade. 
Ora, o entendimento firmado nas ADI $n^{0} 72,242,1254,1434$ e 3522, foi o de que o AGU, deveria assumir, na condição de garante e curador da presunção de constitucionalidade, a defesa irrestrita da validade jurídica da norma impugnada.

Todavia, no julgamento de uma Questão de Ordem, no bojo da ADI nº 3916, o Tribunal qualificou seu entendimento.

Trata-se a ADI no 3916 de uma ação direta de inconstitucionalidade ajuizada pelo Procurador Geral da República em face dos artigos $7^{\circ}$, I e III, e 13, e seu parágrafo único, da Lei distrital $n^{\circ} 3.669 / 2005$, que criou a carreira de atividades penitenciárias e respectivos cargos no quadro de pessoal da Polícia do Distrito Federal. Segundo a inicial proposta pelo PGR, os dispositivos impugnados violam os preceitos contidos nos artigos 21 , XIV e $32, \S 4^{\circ}$, da CF, uma vez que as normas impugnadas reformulam a organização da Polícia Civil do Distrito Federal, em violação a competência exclusiva da União para a providência em epígrafe.

Preliminarmente, o Ministro Marco Aurélio, diante do parecer da Advocacia Geral da União que se manifestava pela declaração de inconstitucionalidade da lei impugnada, reputou que o processo não estava devidamente aparelhado, pois nos termos do $\S 3^{\circ}$ do art. 103 da CF caberia ao Advogado-Geral da União defender o ato ou texto impugnado, e não manifestar-se pela sua inconstitucionalidade, como fizera.

A Corte, contudo, a despeito do entendimento do relator, entendeu ser necessário fazer uma interpretação sistemática no sentido de que o $\S 3^{\circ}$ do art. 103 da CF admite que em algumas situações específicas seja possível que o AGU se manifeste pela inconstitucionalidade do preceito em discussão.

Daí se vê que a interpretação literal do art. $103, \S 3^{\circ}$, da $\mathrm{CF}$, causaria relevantes problemas práticos, como obrigar o Advogado Geral da União a defender a constitucionalidade de lei impugnada através de ADI proposta pelo Presidente da República, onde tal documento, necessariamente, seria elaborado pelo próprio AGU. Ou, ainda, defender, igualmente a constitucionalidade de texto de lei que recebera o veto do Presidente, albergado em Parecer do AGU, assim como o obrigar a defender determinado ato cuja inconstitucionalidade já fora reconhecida pelo STF. 
Contudo, diferentemente do caso anterior (alcance do preceito normativo inserto no art. 52, X da CF), observa-se a plena adequação da mutação com a Constituição vigente. Sendo a bem da verdade, uma hipótese híbrida de mutação, na qual a realidade foi importante para a decisão tomada, haja vista a oposição de interesses no caso entre a União e o Distrito Federal, assim como também representou uma mudança, um avanço da interpretação que vinha sendo construída acerca do preceito em evidência.

Enfim, todos esses casos demonstram uma disparidade entre o conteúdo do texto normativo constitucional e a realidade, bem como entre a interpretação que é dada pelos tribunais, ou ainda a obsolescência do texto constitucional, mostrando-se claramente uma mudança realizada pelo Judiciário, ainda que esta se restrinja objetivamente à oposição entre julgados.

Em nenhum destes julgados acima, como dantes mencionado, foi reconhecido unanimemente que estávamos diante do instituto da mutação constitucional de modo expresso. É que o Supremo Tribunal Federal parece sofrer certo receio em fundamentar os julgados com base na existência de uma mutação, de modo que os argumentos normalmente subtraem da discussão essa temática.

O fato é que a mutação constitucional, tal como entendida no presente trabalho, a despeito de não mencionada expressamente por todos os ministros como argumento de decidir, está presente em todas essas decisões, à exceção da hipótese em que se apontou para uma espécie de mutação inconstitucional.

Pois bem, analisadas as decisões do Supremo Tribunal Federal, passemos a nos posicionar sobre os limites possíveis e desejáveis nestes tipos de mutabilidade de normas constitucionais. 


\section{CAPÍtULO III - MUTAÇÃO CONSTITUCIONAL E LIMITES POSSÍVEIS: POSTULADOS DEMOCRÁTICOS, TEXTO NORMATIVO E JURISPRUDÊNCIA}

Uma vez estabelecido o conceito, inclusive de Constituição e analisados os tipos de mutação constitucional, cabe, agora, perscrutar em que sentido as decisões mutacionais podem se mostrar legítimas e onde encontram limites ${ }^{111}$. Afinal, estamos falando da mudança do conteúdo de preceitos constitucionais por agentes que não detém, a princípio, o poder de reforma formal do pacto político e social inserto no texto constitucional.

Com efeito, ao Judiciário, mais precisamente, ao Supremo Tribunal Federal, compete a garantia da Constituição. E garantia, tal qual no futebol, significa defesa, de forma que a um zagueiro não compete precipuamente fazer os gols de seu time, mas guardar a sua meta, de modo que ao Supremo Tribunal Federal, na mesma proporção, não compete reescrever o pacto social, político e jurídico (fazer os gols), mas sim guardar, defender este pacto institucionalizado em um documento escrito denominado Constituição.

O raciocínio conservador - self restraint -, de certo modo aqui exposto, em relação à condição de guarda da Constituição conferida ao Supremo Tribunal Federal importa um retorno à moldura proposta por Hans Kelsen ${ }^{112}$, mas não a defesa propriamente dita da existência de uma única decisão correta, conforme defendido por Ronald Dworkin ${ }^{113}$.

\footnotetext{
${ }^{111}$ Cf. HESSE, Konrad. Limites da Mutação Constitucional. Temas Fundamentais do Direito Constitucional. Inocêncio Mártires Coelho (Trad.). São Paulo: Saraiva, 2009. p.148-171.

112 "Em todos estes casos de indeterminação (polissemia dos textos), intencional ou não, do escalão inferior, oferecem-se várias possibilidades à aplicação jurídica. $\mathrm{O}$ ato jurídico que efetiva ou executa a norma pode ser conformado por maneira a corresponder a uma ou outra das várias significações verbais da mesma norma, por maneira a corresponder a vontade do legislador - a determinar por qualquer forma que seja - ou, então, à expressão por ele escolhida, por forma a corresponder a uma ou outra das duas normas que se contradizem ou por forma a decidir como se as duas normas em contradição se anulassem mutuamente. O Direito a aplicar forma, em todas estas hipóteses, uma moldura dentro da qual existem várias possibilidades de aplicação, pelo que é conforme ao Direito todo ato que se mantenha dentro deste quadro ou moldura, que preencha esta moldura

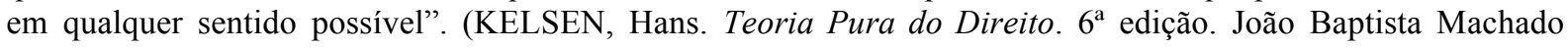
(Trad.). Coimbra: Armínio Amado, 2003. p.390).
}

${ }^{113}$ DWORKIN, Ronald. O Império do Direito. Jefferson Luiz Camargo (Trad.). 2a ed. São Paulo: Martins Fontes, 2007. 
É que, como pontua Marcelo Neves ${ }^{114}$

O problema está exatamente em delimitar as fronteiras entre as interpretações justificáveis e as que não são 'atribuíveis' aos textos constitucionais e legais no Estado Democrático de Direito, [pois] a possibilidade de mais de uma decisão justificável à luz de princípios e regras constitucionais parece-me evidente, [já que] não se trata de extrair arbitrariamente de uma infinidade de sentidos dos textos normativos a decisão concretizadora, nos termos de um contextualismo decisionista, [haja vista, saber ser] insustentável a concepção ilusória de que só há uma solução correta para cada caso, conforme os critérios de um juiz hipotético e racionalmente justo.

Desse modo, não se trata de restringir o fenômeno da mutação constitucional ou mitigar seus efeitos, mas sim, melhor compreendê-lo a fim de que ele não autorize a arbitrariedade judicial, constante na admissão da hipótese na qual, segundo as palavras do Ministro Eros Grau "o próprio texto normativo é substituído por outro" "115, sendo este outro, criação "arbitrária ${ }^{116 ", ~ d o ~ J u d i c i a ́ r i o . ~}$

\footnotetext{
${ }^{114}$ NEVES, Marcelo. Entre Têmis e Leviatã: uma relação difícil: o Estado Democrático de Direito a partir e além de Luhmann e Habermas. São Paulo, 2006 p. 207.

${ }^{115}$ Cf. Voto do Ministro Eros Grau nos autos da Reclamação n ${ }^{\circ}$. 4.335.

${ }^{116}$ Exemplo de tais arbitrariedades podem ser extraídas da seguinte notícia veiculada no sítio do Consultor Jurídico, sob o título "Ativismo judicial estica limites da justiça": "não é só o Supremo Tribunal Federal que está fazendo o chamado ativismo judicial. As instâncias inferiores, mais perto do cidadão, estão a todo vapor procurando a melhor maneira de fazer Justiça, ainda que para isso precisem ir além do que diz a lei. A prática, embora comum, ainda é polêmica. É vista com bons olhos por uma parte da comunidade jurídica, que considera importante que o Judiciário supra a inércia legislativa do Congresso. Já outra parte entende que juízes não podem inventar normas, mesmo que seja para garantir direitos. Recentemente, um juiz da cidade de Taperoão (PB) determinou toque de recolher às $21 \mathrm{~h}$ para menores de 12 anos. Em Conceição de Coité (BA), um juiz condenou um homem por furto, mas não mandou para cadeia. A pena, neste caso, foi arrumar um emprego. Na Paraíba, o toque de recolher imposto teve como base os altos índices de violência na região. Na Bahia, o juiz agraciou o acusado por entender que ele passou a infância e adolescência lançado à sorte, esquecido pelo Estado. Em Goiás, a titular do Juizado Especial de Águas Lindas criou um projeto chamado Kit Educação, que consiste na compra de material escolar com dinheiro das transações penais. Juízes de execução criminal de Porto Alegre decidiram há um mês que, sem vagas no sistema prisional, mandados de prisão não deverão ser expedidos no Rio Grande do Sul. No campo do Direito de Família, um entendimento aplicado muitas vezes por magistrados para obrigar o pai a indenizar o filho por abandono afetivo já caiu por terra no Superior Tribunal e Justiça. Os ministros da $4^{a}$ Turma decidiram que não cabe indenização por dano moral decorrente de abandono afetivo. Ou seja, a Justiça não pode obrigar um pai a dar afeto para o seu filho. Os juízes que entendem que cabe a indenização embasam a decisão num princípio amplo que é o da dignidade da pessoa humana". Disponível no endereço $<$ http://www.conjur.com.br/2009-jul-12/ativismo-judicial-ainda-causa-polemica-comunidade-juridica $>$. Acesso em 15.10.2010.
} 
Diante de tais premissas, percebe-se que a legitimidade e o limite de uma mutação podem, em determinado sentido, coincidirem, mas, na verdade, são interdependentes, pois o que dá legitimidade à mutação constitucional, por outro prisma a limita de tal modo que o limite e a legitimidade estão intrinsecamente ligados. A legitimidade é aceitação, referência e adequação dogmática, já o limite se traduz no campo de atuação legítima do instituto, ou seja, até onde uma decisão judicial pode caminhar sem que ataque os fatores de legitimidade dantes mencionados.

Nesse sentido, sublinha-se como importantes instrumentos de bloqueio possíveis ao desborde da Constituição pelo instrumento da mutação, o seu texto normativo, os postulados da democracia e o respeito aos precedentes jurisprudenciais, elementos estes que em caso de inobservância podem conduzir a uma mutação inconstitucional do preceito analisado, ainda que por si mesmos, sejam conceitos genéricos e de difícil precisão.

O texto normativo representa o desejo inicial do legislador sobre a compreensão de determinados fatos da vida. Sendo assim, a mutação constitucional deve possuir como referência inicial o texto e uma vez ligada a esse texto normativo ela se legitima, ao passo que nele, igualmente, encontra limites, a despeito da mutação representar em maior ou menor medida um aperfeiçoamento do programa normativo.

Isso, contudo, não significa pugnar por uma interpretação autêntica dos textos legais, ou mesmo ressuscitar a interpretação baseada na vontade do legislador ou um retorno a escola da exegese, mas sim lembrar que a soberania permanece com o povo, que o exerce pelo processo de representação política, mediante a atividade do parlamento, e que não se pode, pois, desvirtuar a ordem natural das coisas e subverter prescrições legais, negando-as sob o pálio de uma pretensa mutação constitucional.

Já a democracia ${ }^{117}$ e tudo o que importa ao Poder Legislativo e seu produto de atuação não podem, gratuitamente, serem repelidos. Com efeito, pois representam a vontade política da nação e, de uma forma ou de outra, é o instrumento mais hábil a legitimar uma

\footnotetext{
117 "Tradicionalmente, o conceito de democracia tem sido objeto da filosofia política. Esta tematizou o conceito político de democracia, ou seja, a democracia é vista como um regime de governo, isto é, como um modelo de articulação institucional do poder." (Barzotto, Luis Fernando. A Democracia na Constituição. Rio Grande do Sul: Editora Unisinos, 2005, 9p.)
} 
opção política, pois, abstratamente, parece conferir participação sempre a um maior número de pessoas possível. Deveras, a democracia representativa apoia-se de modo tautológico na representação da vontade de grupos sociais e, por consequência, nas sociedades modernas, na representação possível de um parlamento.

A jurisprudência, por sua vez, possui estreita ligação com o princípio da segurança jurídica e, na ausência de regime jurídico apto a definir as condições de regular modificações de sua orientação consolidada, imperioso se torna que o trato de sua mudança seja o mais cuidadoso possível. De tal forma que o discurso sedutor de mudança não deve ser utilizado para inserir regras arbitrárias no ordenamento.

Nesses termos, passa-se a analisar as implicações de cada um dos três institutos para o escopo delimitado do presente capítulo, analisando a raiz do sistema político, a questão da representatividade e sua influência no processo de reconhecimento e construção de mutações constitucionais, com referência principal à questão jurisprudencial e ao texto normativo constitucional.

\subsection{Mutação Constitucional e o déficit democrático}

O sistema político de governo brasileiro, assim como boa parte dos Estados ditos ocidentais ${ }^{118}$, consagrou o modelo democrático como forma de tomada de decisões e condução dos assuntos pertinentes ao desenvolvimento da nação e do direito. Sendo até mesmo impensável, um arquétipo, no qual a maioria não governe ou ao menos assinta, seja, por qualquer motivo, com o centro de tomadas de decisões. Percebe-se tal estado de coisas

\footnotetext{
${ }^{118}$ Como bem destaca Amartya Sen: "Sem dúvida, a estrutura institucional da prática contemporânea da democracia é em grande medida o produto da experiência europeia e americana dos últimos séculos. Reconhecêlo é muito importante, pois esses desenvolvimentos institucionais foram extremamente inovadores e, por fim, muito eficazes. Resta pouca dúvida de que existe aqui uma grande 'realização ocidental'. Entretanto, como observou Alexis de Tocqueville, o grande historiador da democracia norte-americana no início do século XIX, " a grande revolução democrática', que então acontecia na Europa e nos Estados Unidos, era algo 'novo' mas também uma expressão da 'tendência mais contínua, antiga e permanente conhecida da história'. Embora o próprio esclarecimento de Tocqueville sobre essa tese radical não se estenda além do espaço da Europa e do tempo do século XII, seu argumento geral tem uma relevância muito mais abrangente. Ao ponderarmos os prós e os contra da democracia, devemos reconhecer devidamente que o fascínio pela governança participativa apareceu e reapareceu, com certa consistência, em diferentes partes do mundo". (SEN, Amartya. A ideia de Justiça. Denise Bottmann; Ricardo Doninelli Mendes (Trads). São Paulo: Companhia das Letras, 2011. p. 357).
} 
não só pela análise dos fatores históricos e políticos, mas também pela análise da ordem jurídica vigente, sobretudo do sistema político de índole constitucional.

A democracia, sabe-se, tem se assentado em duas formas principais de manifestação, quais sejam, o respeito ao princípio majoritário quanto à tomada de decisões e, nas constitucionais, pelo respeito igualmente aos direitos fundamentais.

A regra majoritária é algo sedutor e inafastável, basta lembrar a hipótese do bote salva vidas, no qual pessoas à deriva, ao perceberem seu iminente naufrágio e em razão do peso dos ocupantes, passam a deliberar acerca de qual decisão tomar, sabendo-se, de antemão, que o único caminho possível é a supressão de peso do bote e isso só pode se dar com a retirada de uma ou de mais pessoas.

Nota-se que nessa situação hipotética, a decisão pode se dar por maioria, obtendo legitimidade desde que respeite determinado procedimento, cuja maioria, igualmente, terá que estar de acordo. Afinal, se existir divergência capaz de inviabilizar a construção de uma maioria, não haverá meios de se impor a decisão ao final tomada, restando apenas o uso da força como via adequada à solução de peso do bote. Então teremos, naturalmente, duas decisões majoritárias, a primeira, resolvendo a forma de deliberação, e a última sobre a decisão de quem será jogado ao mar.

Essa circunstância hipotética denuncia o quanto a regra da maioria se encontra intrínseca ao modo de deliberação humana; fora desta circunstância, apenas uma decisão derivada de autoridade ou de autoritarismo é possível.

Pois bem, sabe-se que a Constituição representa uma determinada maioria, mas à medida que se protrai no tempo e se afasta do momento de sua criação, aliado ao crescimento populacional, um conflito de gerações relevante e de maiorias distintas ${ }^{119}$ pode se instaurar. Afinal, passados 25 anos da Constituição, muitos brasileiros que hoje se submetem às suas prescrições, talvez nem fossem nascidos à época da aprovação e, por consequência,

\footnotetext{
${ }^{119}$ Nesse cenário, do confronto de duas maiorias formadas em épocas diversas, a primeira, ou seja, a que se estabeleceu em momento temporal anterior, prevalece sobre a segunda, dada a rigidez e supremacia do texto constitucional, bem como a existência de cláusulas pétreas.
} 
não puderam dar seu assentimento e nem foram representados neste processo, no entanto, estão hoje a ela vinculados por um raciocínio hipotético e pressuposto.

Se observarmos o período de aprovação pela Assembléia Constituinte de 1988 da Constituição, o Brasil contava com uma população significativamente inferior à atual, o que, por óbvio, explica um certo descompasso entre os quereres atuais e os consagrados em seus preceitos normativos.

O fato é que em democracias consolidadas, o fascínio pelo princípio majoritário é algo intrínseco a esses processos, até porque as alternativas restantes não deixam ao cidadão opções muito sedutoras e eficazes. Logo, em regra, as democracias se assentam sobre a regra da maioria, no entanto, isso não pode significar apenas um apego ao procedimentalismo valorativo. Com efeito, pois, acaso assim pensado, inúmeros problemas, como demonstra a própria História mundial, podem minar a democracia vigente. A respeito, veja a experiência alemã no período que antecedeu a subida de Hitler ao poder e culminou com a Segunda Guerra Mundial.

É sabido, ainda, que o direito nem sempre reflete em sua integridade a vontade da maioria, ou mesmo o pensamento social dominante. Ora, diversas pesquisas sociológicas demonstram, como se percebe em trabalhos de escol como "A cabeça do brasileiro"120, a existência de um hiato entre o querer social, as normas e o direito aplicado. As circunstâncias de tal reflexo negativo da vontade "geral" são as mais variadas, desde o descompasso temporal de aprovação de leis, Constituição e a evolução dos costumes, até a própria questão da deficiência de representatividade, sem deixar de ponderar a existência de outras questões marginais.

E aqui, não se trata, a princípio, de nenhuma crítica quanto a não correspondência entre vontade geral e legislação posta ou aplicada. Decerto, essa vontade geral, em alguns casos, tende a mitigar e aniquilar direitos das minorias, pois, invariavelmente, o prisma de atuação é eminentemente individual. Assim, se o indivíduo compõe uma maioria dominante é aceitável que seus anseios coincidam com os de sua clivagem, fazendo com que as minorias sejam alijadas do processo.

${ }^{120}$ ALMEIDA, Alberto. A cabeça do brasileiro. São Paulo: Record, 2009. 
Daí a importância da mantença de direitos fundamentais e de seu respeito, pois a maioria amorfa é irracional e incapaz de, em situações limites, respeitar as condições especiais.

De outro lado, cumpre destacar que a decisão majoritária se aproxima dos modelos eleitorais diretos, nos quais a população pela maioria de seus votos elege aqueles que irão lhe representar. Contudo, sobretudo no Brasil, e igualmente nos Estados Unidos ${ }^{121}$, nem sempre essa regra da maioria é seguida a risca, ou melhor, temos apenas uma aparente maioria formada.

Com efeito, excetuando-se as eleições para presidente, governadores e prefeitos, observamos, nas eleições proporcionais e mesmo majoritárias para o Senado, determinadas incongruências que nos faz pensar a respeito do quanto majoritário acabam por se moldar às nossas instituições.

As eleições proporcionais se fundam em critérios populacionais que, na base de um homem, um voto acaba por "sub-representar" determinados estados muito populosos e "super-representar" estados de menor população, ainda que a proporção estabelecida siga determinado padrão matemático.

Vê-se, pois, não ser possível a esta equação estabelecer uma paridade eficaz, precisa e literal a respeito da máxima um homem, um voto, em um sistema que trabalha com limites mínimos e máximos de cadeiras a serem ocupadas, como no caso da Câmara dos Deputados, na qual a representatividade varia de 8 a 70 cadeiras, por Estado da federação.

A inobservância da regra da maioria é ainda mais gritante perante uma instituição como o Senado da República que, a despeito de possuir como função precípua a representação paritária de todos os Estados da federação, ao se incluir no processo legislativo como casa revisora, ou mesmo propulsora de projeto de leis, distorce-a.

Decerto, pois é possível que projetos de lei sejam aprovados na câmara por número substancial de deputados representativos de uma população igualmente relevante, mas

\footnotetext{
${ }^{121}$ DAHL, Robert A. How Democratic is the Constitucion? Second Edition. New York: Yale University Press, 2003.
} 
que sejam derrubados por uma maioria de senadores, cuja população não seria compatível, por exemplo, nem com o Estado de São Paulo.

Exemplificando, uma proposta de emenda constitucional, cujo quórum de aprovação é de três quintos dos membros do Congresso, necessita, para ser aprovada, que ao menos 308 deputados votem a favor desta proposta. Seguindo a regra de distribuição de parlamentares, isso equivaleria à soma de todos os deputados representativos de nove Estados, ou seja, um terço da federação, como São Paulo (70), Rio de janeiro (45), Minas Gerais (55) e Rio Grande do Sul (30), Paraná (29), Pernambuco (24), Ceará (24), Pará (21) e Santa Catarina (17), cujas populações somadas importam no montante aproximado de 128 milhões de pessoas ${ }^{122}$, isto é, importam em $66 \%$ da população.

Tal proposta, conforme rege a Constituição Federal, necessita de igual aprovação do Senado federal, seguindo mesmo quórum. Todavia, como no Senado a composição é inferior, dois quintos dos votos mais um são suficientes para a não aprovação do projeto de emenda mencionado, de modo que 33 (trinta e três senadores) Senadores (representativos de 11 Estados da Federação, com população inferior a $20 \%$ do total de brasileiros), votando contra o projeto de emenda de nosso exemplo, poderão impedir que o desejo de mudança, aprovado na câmara, representativo de mais de 65\% (sessenta e cinco por cento da população brasileira), seja inviabilizado.

Assim, 33 Senadores, representantes de 11 Estados, cuja população é inferior, por exemplo, ao Estado de São Paulo, podem se opor a um projeto de 128 (cento e vinte e oito) milhões de pessoas. Ora, isso é respeitar o processo majoritário? Se serve de consolo, situação semelhante também se opera no caso estadunidense ${ }^{123}$.

Daí se vê que a própria Constituição, apesar de se valer do princípio majoritário, inclusive como critério de resolução de controvérsias, no âmbito do Supremo Tribunal Federal, é veladamente refratária em algumas circunstâncias à regra do respeito à vontade da maioria em um sentido literal.

\footnotetext{
${ }^{122}$ Segundo dados do IBGE de 2010, para um total de 193 milhões de brasileiros.

${ }^{123}$ DAHL, Robert A. How Democratic is the Constitucion? Second Edition. New York: Yale University Press, 2003.
} 
O quanto descrito serve para desmitificar a regra da maioria e o princípio majoritário como algo sacralizado do processo democrático, de modo que podemos, a bem da verdade, tão somente nos referir a uma democracia possível. Com efeito, visto que diante da complexidade do tecido social, nota-se que o estabelecimento de mecanismo de democracia direta resta inviável, podendo apenas se mostrar eficaz em determinados momentos pontuais, como na admissão de referendos e plebiscitos e nas votações para eleger os detentores de mandados políticos determinados, como visto acima, Prefeitos, Governadores e Presidente da República.

Nesses termos, a democracia assenta-se mais na possibilidade de debate público, na igualdade das pessoas, na segurança de participação nos debates políticos do que propriamente, e, necessariamente, no respeito incondicional à regra inscrita no princípio majoritário. Sendo que, eventual descompasso não poderá servir como subterfúgio para que haja um domínio da esfera jurídica por apenas um ator central, já que as consequências deste fenômeno, além de se oporem a própria função do direito, possui consequências incalculáveis.

Em suma, ainda que imperfeitamente, a Constituição, as leis e, em certa medida, os atos legiferantes do Poder Executivo representam o condensamento das ideias e discussões políticas travadas no seio da sociedade ${ }^{124}$, elas são a resultante da participação e oposição no processo de decisão pública. A mediação legislativa assume um papel central na discussão e fixação dos rumos de uma sociedade, enquanto que a atitude judicial ${ }^{125}$ desbordante distorce esse processo, pois insere no contexto da decisão pública, uma visão particularizada dos fatos, que nem sempre representam uma vontade social dominante, a tal ponto de, sob o guarda-chuva da técnica jurídica, atos legislativos serem solapados. A

\footnotetext{
124 "De fato, todo o procedimento parlamentar, com sua técnica dialético-contraditória, baseada em discursos e réplicas, em argumentos e contra-argumentos, tende a chegar a um compromisso. Este é o verdadeiro significado do princípio da maioria na democracia real. Portanto, seria melhor dar a tal princípio o nome de princípio majoritário-minoritário, uma vez que ele organiza o conjunto dos indivíduos em apenas dois grupos essenciais, maioria e minoria, oferecendo a possibilidade de um compromisso na formação da vontade geral, depois de ter preparado esta última integração obrigando ao compromisso acima mencionado, que é a única coisa que pode permitir a formação tanto do grupo da maioria quanto do grupo da minoria: relegar a segundo plano o que separa os elementos a serem unidos, em favor daquilo que une". (KELSEN, Hans. A democracia. Ivone Castilho Benedetti e outros (Trad.). São Paulo: Martins Fontes, 2000. p. 70).

${ }^{125}$ RAMOS, Elival da Silva. Controle de Constitucionalidade no Brasil: perspectivas de evolução. São Paulo, Saraiva, 2010. p. 104 e ss. e Barak, Aharon. The Judge in a Democracy. Princeton University Press, New Jersey, 2006.
} 
sociedade, por sua vez, fica atônita diante do engessamento do debate e de sua elitização, posto que o Judiciário nada mais é que um elemento aristocrático no processo democrático.

Dessa forma, entende-se que a mutação constitucional como inerência lógica e instrumento do processo descrito acima, não pode ficar flutuante em uma zona cinzenta em que não haja limites ao seu espectro de atuação, razão pela qual se traz a contribuição de Jeremy Waldron ${ }^{126}$, o qual, em discussão sobre o tema, assim se pronuncia, em uma tentativa de resgatar a importância do direito legislado:

As pessoas convenceram-se de que há algo indecoroso em um sistema no qual uma legislatura eleita, dominada por partidos políticos e tomando suas decisões com base no governo da maioria, tem a palavra final em questões de direitos e princípios. Parece que tal fórum é considerado indigno das questões mais graves e mais sérias dos direitos humanos que uma sociedade moderna enfrenta. O pensamento parece ser que os tribunais, com suas perucas e cerimônias, seus volumes encadernados em couro e seu relativo isolamento ante a política partidária, sejam um local mais adequado para solucionar esse caráter. Não estou convencido disso; mas não é minha intenção argumentar aqui contra a revisão judicial da legislação. Penso que é imperativo, porém, que tal reforma não seja empreendida sem uma percepção clara do que é valioso e importante na ideia de uma legislatura e da dignidade e autoridade que a legislação pode angariar.

Não se nega aqui que a função jurisdicional também contribua para a formação da vontade geral. Todavia, determinar a verticalização das eleições, como se deu em 2002, ou mesmo disciplinar o novel instituto da fidelidade partidária, inaugurando institutos com a justa causa, como circunstância apta a perda de mandato representativo, são decisões eminentemente políticas cujo foro natural residiria no debate popular e não, por óbvio, na técnica jurídica interpretativa de uma corte judicial, como o Supremo Tribunal Federal.

\footnotetext{
${ }^{126}$ WALDRON, Jeremy. A dignidade da legislação. Luís Carlos Borges (Trad). São Paulo: Martins Fontes, 2003.
} 
Nesta conjuntura, não é raro observar que alguns juízes tenham sido acusados de legisladores ${ }^{127}$ e 128 , de usurpadores do poder político-representativo conferido aos parlamentares e de estabelecerem uma espécie de ditadura, ao substituir a maioria parlamentar pelas maiorias dos tribunais recursais ${ }^{129}$.

Neste sentido, cabe citar o constitucionalista francês, Georges Burdeau, o qual, investigando os efeitos do tema proposto, vislumbrou no fenômeno, o surgimento de uma nova espécie de poder constituinte, o difuso, a ser exercido pelos tribunais ${ }^{130}$ quando no exercício da jurisdição constitucional.

Ora, a atuação positiva dos tribunais e o abandono do dogma do legislador negativo como um modelo a ser seguido e mais condizente com os ideais postos na relação entre política e direito, sabe-se, faz com que o Tribunal inove na ordem jurídica, e ao fazê-lo, vemo-nos diante de um dilema político-jurídico, a saber, como conciliar a decisão majoritária do processo político-legislativo com as decisões judiciais que avançam cada vez mais sobre as questões de natureza política, bem como sobre a pretensa defesa das minorias?

Enfim, será que, de fato, há uma transformação da norma em texto simbólico? O Supremo tem o poder de retirar eficácia de norma constitucional? A democracia comporta tal atuação? O fenômeno da hermenêutica constitucional permite essa atualização incessante e

\footnotetext{
127 “Na sua 'Holdsworth Lecture' de 1965, Lord Diplock disse que 'em razão de sua própria função, os tribunais estão constrangidos a agir como legisladores'. (CAPPELLETTI, Mauro. Juizes Legisladores? Carlos Alberto Alvaro de Oliveira (Trad.). Porto Alegre: Sergio Antônio Fabris Editor, 1993. p. 73).

${ }^{128}$ Também alerta para essa problemática o Professor Manoel Gonçalves Ferreira Filho, para quem "[...] a Constituição faz o Judiciário de censor do Legislativo e, se não o traz a legiferação, o deixa no limiar disso. Mais recentemente, em 2007, o Supremo Tribunal Federal, em razão da omissão legislativa em regulamentar o direito de greve do servidor público, mandou aplicar a lei comum sobre a greve no setor privado. Deu assim um passo á frente no sentido de assumir um papel legiferante (e também no sentido de sua politização). (FERREIRA FILHO, Manoel Gonçalves. Aspectos do Direito Constitucional Contemporâneo. 2a . ed. São Paulo: Saraiva, 2009. p. 204-205).

${ }^{129}$ WALDRON, Jeremy. A dignidade da legislação. Luís Carlos Borges (Trad). São Paulo: Martins Fontes, 2003. p. 156-157.

${ }^{130}$ Georges Burdeau in Traité de science politique, 1969, v. 4, p. 246-247 apud BARROSO, Ob. cit. p. 127 , afirma: "Se o poder constituinte é um poder que faz ou transforma as constituições, deve-se admitir que sua atuação não se limita às modalidades juridicamente disciplinadas de seu exercício [...] Há um exercício quotidiano do poder constituinte que, embora não esteja previsto pelos mecanismos constitucionais ou pelos sismógrafos das revoluções, nem por isso é menos real. [...] Parece-me, do todo modo, que a ciência política deve mencionar a existência desse poder constituinte difuso, que não é consagrado em nenhum procedimento, mas sem o qual, no entanto, a constituição oficial e visível não teria outro sabor que os registros de arquivo".
} 
descompromissada do texto constitucional acompanhada da mudança literal do próprio dispositivo? E ainda, o limite existente no próprio texto, no que concerne a seu sentido semântico e prognóstico de enunciados normativos é realmente eficaz, legítimo e necessário? Ou, afinal, todas essas decisões seriam legítimas, pois, decorreriam, em maior ou menor proporção de uma omissão legislativa, de uma falha de representatividade, na qual cabe ao Judiciário sanar?

É o que se tenta responder.

\subsection{Texto normativo como ponto de partida e referencial último das mutações constitucionais}

A Constituição analítica e a profusão de leis no Brasil só demonstram que a democracia e o direito aqui existente são necessariamente subproduto ou, ao menos, condicionado pela norma positiva.

Por termos passado desde a independência por diversos momentos constituintes, grandes transformações sociais e políticas, nossa sociedade parece ter construído um sentimento de ser o texto positivo o único instrumento capaz de propor e efetivar mudanças ${ }^{131}$.

\footnotetext{
${ }^{131}$ Nesse sentido, veja-se o que disse Claudio Pacheco citado por José Afonso da Silva, "Outro elemento identificador das nossas Constituições, que procuramos não perder de vista, é o da sua elaboração teórica, idealizada sem uma percepção nítida, uma suficiente assimilação das nossas realidades. As nossas Constituições têm sido muito mais científicas que históricas, muito mais racionais que vividas, revelando-se mais pela imaginação que pela experimentação. Têm sido apreciáveis repositórios de fórmulas e princípios, colhidos e selecionados em boa doutrina, pelo quê as suas realizações e as suas vigências tiveram longamente uma catadura de verdadeira deturpação. Somente nas três últimas décadas estamos evoluindo para alcançar um novo e harmonioso destino constitucional, em que as nossas instituições poderão refundir-se e reviver em ajuste com a nossa realidade política e social. Vamos assim ganhando oportunidade para remediar o chocante desajuste que nos tem resultado da nossa confiança exuberantemente juvenil no efeito mágico das enunciações da lei escrita, à qual estamos sempre pedindo reformas ou aperfeiçoamentos de suposto efeito imediato para curar velhos vícios, deficiências ou omissões da nossa formação coletiva, que, em verdade, somente por sedimentação lenta e progressivo aperfeiçoamento seriam efetivamente corrigidas." (SILVA, José Afonso. Constitucionalismo Brasileiro: Evolução Institucional. São Paulo: Malheiros Editores, 2011. p. 22).
} 
Passamos por sete Constituições, o que demonstra a importância do texto como fator indutor e concretizador de mudanças, herdeiro de um modelo liberal que viu no positivismo um modo de se estabelecer a igualdade ${ }^{132}$.

Assim, enquanto a lei assume quase que um caráter purificado, muito mais temos a dizer da norma constitucional, que é ainda superior em caráter. Já as decisões judiciais, em oposição à abstração das leis, tendem a ser parciais. Essa visão idealizada do fenômeno é inconscientemente arraigada no imaginário do povo brasileiro, sendo a Constituição a oportunidade de sacralizar pactos parciais com a sociedade a depender do interesse envolvido.

Decerto, pois, a Constituição, ao contrário de só dispor sobre direitos e garantias fundamentais e organização do Estado e Poder, vai além, e ao mesmo tempo, dispõe sobre direitos trabalhistas do setor privado, do setor público, sobre normas ambientais, sobre normas da seguridade social, sobre composição de câmara de vereadores, sobre composição e formação de polícias, tudo a denotar a existência de pactos setoriais que nada acrescentam à experiência constitucional, mas apenas fortalecem no imaginário popular brasileiro quanto à sacralização de um direito e, acima de tudo, a inscrição deste.

Pois bem, o princípio democrático, a jurisprudência, assim como o texto normativo importam parâmetros aptos a limitar a ação de uma mutação constitucional, sendo o texto, notadamente, o elemento mais importante. E não poderia ser diferente, pois em um sistema baseado na igualdade, de matriz liberal e positiva, a importância do texto normativo é central na definição e alcance de quaisquer direitos. Quer-se dizer, a mutação constitucional mostra-se condicionada a um só tempo pela tradição jurisprudencial, pelos valores democráticos e, acima de tudo, pelo texto normativo, apesar de importar em uma ressignificação deste.

\footnotetext{
${ }^{132}$ A igualdade é busca, talvez até natural, dos povos ocidentais, e o único meio seguro de propagá-la é estabelecer a igualdade de todos perante a lei, ou seja, a lei como produto do coletivo, como subproduto da participação popular, como consequência da democracia, do princípio majoritário a todos sujeita. O fascínio está na sujeição a algo impessoal, sem forma humana, como um rei, um imperador, mas derivada da natureza humana que a todos subjuga de maneira igualitária.
} 
Logo, a semântica normativa se mostra como um vetor importante para a definição de limites, e portanto óbice à mutação constitucional. Com efeito, em um sistema que preza pela força normativa da Constituição, como agente que busca modificar a realidade, não se pode prescindir do significado dos textos na atividade de jurisdição constitucional e esse significado é certo pode ser enriquecido por argumentos originalistas.

Sendo assim, como admitir que uma mudança do cenário constitucional seja possível, sem que o limite textual seja respeitado? Sem que a semântica natural e possível desta norma seja referencial de decisão?

Ora, propõe-se como resposta à problemática enfrentada a ideia trazida pelo professor Luís Roberto Barroso ${ }^{133}$ e também em certo sentido sufragada pelo professor Elival da Silva Ramos ${ }^{134}$, qual seja, a de que a mutação constitucional está mitigada por duas hipóteses: as possibilidades semânticas do relato da norma, vale dizer, os sentidos possíveis do texto que se está sendo interpretado ou afetado e a preservação dos princípios fundamentais que dão identidade àquela específica Constituição.

Deste modo, estabelece-se um modelo que idealmente ligado ao self restraint respeita o máximo possível a lógica legislativa e as possibilidades semânticas das disposições, fazendo a interpretação corresponder ao prescrito pelos enunciados normativos, evitando excessos que permitam afirmar exatamente o oposto do texto legal. Pois, ao assim se conduzir, estará a magistratura subtraindo poder da soberania popular e desvirtuando o procedimento democrático, como visto acima.

\footnotetext{
${ }^{133}$ BARROSO, Op. Cit. p.127.

134 "Na escolha da variante exegética (programa normativo) compatível com o espaço de interpretação não se está trabalhando fora da dogmática e sim sob seus pressupostos, já que a opção há de ser justificada racionalmente e de se mostrar coerente com o sistema jurídico em vigor. Admite-se aqui a influência da consciência ética que o intérprete-aplicador partilha com a sociedade em que vive. Não se trata da imposição voluntarista de concepções éticas pessoais, que não atenderiam às necessidades de uma justificação correlata ao desempenho de função estatal, mas da tentativa de expressar o sentimento de justiça radicado no meio social de onde provém o operador do direito e para o qual se dirige. Não se está, por outro lado, a admitir a complementação da ordem jurídica vigente com prescrições provenientes de um direito natural ou de uma ordem objetiva de valores; ainda que se parta de imperativos éticos construídos em consideração ao que melhor convém à pessoa humana, não se poderá jamais recusar a juridicidade de propostas interpretativas distintas, desde que compatíveis com o espaço que se está a densificar". (RAMOS, Elival da Silva. Parâmetros Dogmáticos do Ativismo Judicial em Matéria Constitucional. Tese apresentada à Faculdade de Direito da Universidade de São Paulo, para inscrição em concurso público visando ao provimento de cargo de Professor Titular, junto ao Departamento de Direito do Estado - área de Direito Constitucional, São Paulo, 2009. p. 74-75).
} 
Para evitar excessos, busca-se traçar, a partir de elementos lógicos, uma espécie de moldura na qual o Supremo Tribunal Federal não poderá se afastar, sob pena de se negar à legislação o status que ela merece e deve ocupar, haja vista o perigo da consolidação de um realismo jurídico, que negamos a priori. É que a aprovação de um texto normativo, mesmo consciente de suas limitações, importa na consagração de determinado programa político, que ao não se verificar na realidade produz uma frustação das expectativas e uma desconfiança no seio do sistema jurídico questionando-se, inclusive, a sua capacidade de mediar e legitimar as decisões políticas da sociedade.

Nesse sentido, confere-se importância aos institutos do Estado de direito, da democracia e ao princípio da separação dos poderes, situando-os como limites nos quais a interpretação constitucional ${ }^{135}$ não importe no esvaziamento do conteúdo de preceitos constitucionais, nem tampouco transforme a jurisdição constitucional em um poder de reforma "branca" aristocrática dos cânones fundamentais de uma sociedade, assentada no texto magno.

Portanto, no universo de valoração eficiente dos textos normativos, não se pode subjulgar a importância semântica deste ponto da discussão. Até mesmo porque não se admite, como regra, em nosso sistema, que demandas constitucionais não sejam referenciadas ao texto da norma, já que as prescrições quanto ao cabimento de ações diretas de constitucionalidade e inconstitucionalidades, bem como quanto controle de constitucionalidade concreto (art. 102 e 103 da CF), assim como os referenciais postos para edição de súmula vinculante e a admissão de repercussão geral, assim procedem e exigem.

Eis a importância e o papel do texto normativo.

\footnotetext{
135 Bastos, BASTOS, Celso Ribeiro e Meyer-Pflug, Samantha in Silva, Virgílio Afonso da (org). Interpretação Constitucional. 1 ed. São Paulo: Malheiros, 2007, p. 163 “[...] a atividade interpretativa não é absoluta - é dizer, sem limites. Por mais que a norma constitucional possua uma alto grau de abstratividade, generalidade e imprecisão, é evidente que existem amarras que delimitam o campo de atuação do intérprete. Este, ao realizar seu mister, não pode ir além da expressão literal da norma interpretada e da vontade desta (voluntas legis). Caso o faça, o intérprete atuará como legislador positivo, e não como intérprete, pois estará criando norma jurídica, ao invés de descobrir o sentido da norma constitucional analisada" (sic).
} 


\subsection{Do papel e importância da Jurisprudência no contexto da mutação constitucional}

A jurisprudência igualmente aparece como meio procedimental legitimador e, concomitantemente, limitador da mutação constitucional. Aqui, a exigência se amolda a um impulso à integridade ${ }^{136}$, na visão de Dworkin, um caminhar em direção à solidificação da jurisprudência da qual os julgadores não podem se afastar.

A jurisprudência é a representação consolidada da prática e da interpretação de um determinado conteúdo normativo. A jurisprudência contém em si mesma um limitador, ao qual adere o intérprete, ainda que inconscientemente. Trata-se do dever primário de respeito ao precedente assim como o dever não menos importante de bem motivar uma superação deste (overruling).

A importância do precedente se relaciona com concretização do prncípio da igualdade $^{137}$, na medida em que julgamentos idênticos, ou seja, consequências iguais para casos similares, contribuem para a segurança jurídica, bem como para a efetivação do princípio da igualdade, seja em sua vertente material, seja no seu viés formal.

Reconhece-se, também a existência de "superprecedentes" ${ }^{138}$ (invisible constitution), os quais, dada a sua natureza e importância, passam a integrar quase que por algum modo indescritível, parte da Constituição escrita. São casos e decisões inabaláveis,

\footnotetext{
136 “A interpretação constitucional sob a leitura moral é disciplinada pela exigência de integridade constitucional (...) Os juízes não podem dizer que a Constituição expressa as suas próprias convicções. Não podem pensar que os dispositivos morais abstratos expressam um juízo moral particular qualquer, por mais que esse juízo lhe pareça correto, a menos que tal juízo seja coerente, em princípio com o desenho estrutural da Constituição como um todo e também com a linha de interpretação constitucional predominantemente seguida por outros juízes no passado. Têm que considerar que fazem um trabalho de equipe junto com os demais funcionários da justiça do passado e do futuro, que elaboram juntos uma moralidade constitucional coerente; e devem cuidar para que suas contribuições se harmonizem com todas as outras (...) A vela da Constituição é bem grande, e muitos temem que seja grande demais para um navio democrático". (DWORKIN, Ronald. O Direito da Liberdade: A Leitura moral da Constituição norte-americana. Marcelo Brandão Cipolla (Trad.). São Paulo: Martins Fontes, 2006. p. 15-17).

137 “Um juiz que esteja decidindo o caso McLoughlin (onde foi conferida a indenização) poderia considerar injusta a exigência de indenização por quaisquer danos morais. Mas se ele aceita a integridade, e sabe que a algumas vítimas de danos morais já foi conferido o direito à indenização, terá não obstante uma razão para se pronunciar favoravelmente à sra. McLoughlin.” (DWORKIN, Ronald. O Direito da Liberdade: A Leitura moral da Constituição norte-americana. Marcelo Brandão Cipolla (Trad.). São Paulo: Martins Fontes, 2006. p. 214).
}

${ }^{138}$ TRIBE, Laurence H. The Invisible Constitution. New York: Oxford University Press, 2008. 
inclusive pela atuação do Poder Legislativo. Está-se a falar da Constituição invisível ${ }^{139}$, não escrita, a qual, não se pode negar, integra o sentimento constitucional, sendo aqui esta ideia representada por algo mais amplo, a que, sem pudor, não temos receio em classificar como Constituição. Porém, Constituição diferenciada em relação ao sentido estritamente positivo, pondo o seu texto em um patamar especial em relação à realidade constitucional a sua volta.

Nos Estados Unidos, o professor de Harvard Laurence H. Tribe, identificou esse fenômeno no célebre caso Brown x Board of education, já que a decisão ali contida, seu conteúdo e a superação da questão racial permanecem até hoje, como um valor relevante e quase pétreo da práxis constitucional americana. No Brasil, também não teríamos dificuldade em aplainar situações congêneres.

Nesse prisma, cumpre atentar que o sistema de controle de constitucionalidade no Brasil, tradicionalmente, ao contrário do sistema estadunidense, nunca se apoiou no precedente como elemento importante do processo decisório.

Contudo, recentemente, alguns elementos nos impelem a este caminho, a despeito, de não representarem a cultura do precedente propriamente dita. São eles: a súmula vinculante, a sistemática de recursos repetitivos e repercussão geral, bem como a abstrativização de decisões de controle incidental.

Com a introdução destes elementos ao nosso sistema de controle de constitucionalidade, há de haver um direcionamento da jurisprudência no sentido de respeito ao precedente, tal qual, destacou Luiz Guilherme Marinoni ${ }^{140}$ ao denunciar que:

Não há coragem para denunciar que, diante da variedade das decisões e das interpretações da lei, é necessária uma elaboração teórica capaz de garantir a segurança, a previsibilidade e a igualdade. A doutrina do civil law cometeu um pecado grave ao encobrira necessidade de um instrumento capaz de garantir a igualdade diante das decisões, preferindo preservar um dogma ao invés de

\footnotetext{
${ }^{139}$ Idem.

140 MARINONI, Luiz Guilherme. Juiz não pode decidir diferente dos tribunais. Disponível em $<$ http://www.conjur.com.br/2009-jun-28/juiz-nao-direito-decidir-diferente-tribunais-superiores $>$. Acesso em 26.06.2009.
} 
denunciar a realidade e a funesta consequência dela derivada. A segurança e a igualdade, postuladas na tradição do civil law pela estrita aplicação da lei, está a exigir, num modelo transformado pelo constitucionalismo, o sistema de precedentes, estabelecido para tutelar a segurança no ambiente do commom law, em que a possibilidade de decisões diferentes para casos iguais nunca foi desconsiderada e, exatamente por isto, fez surgir o princípio, inspirador do stare decisis, de que os casos similares devem ser tratados do mesmo modo (treat like cases alike).

Pois bem, a questão relativa à mudança jurisprudencial tem que ser enfrentada sob ao menos três matizes. Uma, existe a questão de saber se o Poder Judiciário está, ou não, vinculado aos seus próprios precedentes e, por isso, pode, ou não, mudar a sua orientação. Dois, é preciso examinar se, podendo aquele alterar seu entendimento, de que modo ele pode fazê-lo, se bruscamente ou apenas suavemente, com regras de transição ou com cláusulas de equidade. E três, é necessário analisar com que efeitos pode ser feita a mudança de orientação, se com efeitos retroativos ou retrospectivos, ou apenas prospectivos ${ }^{141}$.

Nesse diapasão, conforme citado acima, ainda que a mutação resida em uma virada da realidade constitucional, normativa, textual ou jurisprudencial, esse aspecto de mudança não permite que a jurisprudência seja imune ao dever de coerência tão propagado e buscado a partir de instrumentos que nos permitem aproximar a nossa jurisdição constitucional da cultura do fortalecimento dos precedentes.

Logo, nesse sentido, de coerência e de respeito aos precedentes, a jurisprudência representa, ainda que tenuamente, um limite ao conteúdo do reconhecimento ou da inauguração de uma nova mutação constitucional, pois a integridade, ou seja, o respeito ao desenvolvimento, a construção histórica de uma interpretação jurisprudencial, há de permear os argumentos de decisão do Juiz, quando no exercício de sua atividade, sobremaneira, quando se lhe impuser a hipótese de se reconhecer ou propor uma espécie de mutação constitucional.

\footnotetext{
141 ÁVILA, Humberto (2011). Segurança Jurídica: Entre permanência, mudança e realização no Direito Tributário. São Paulo: Malheiros Editores, 2011. p. 462.
} 
Assim, uma vez assentado os limites possíveis às mutações constitucionais, passa-se ao último capítulo deste trabalho, no qual se pretende, após definido o objeto, verificado na jurisprudência e colmatado pelos instrumentos disponíveis, estudar as possibilidades de sua aplicação futura, em termos do sistema jurídico brasileiro. 


\section{CAPÍTULO IV - MUTAÇÃO CONSTITUCIONAL, PANORAMAS DE APLICAÇÃO}

Tomando a mutação constitucional como processo informal de mudança da Constituição e acrescendo uma concepção de direito que confere ao juiz um papel importante, sem se esquecer da relevância do texto em si e de seu programa normativo como pontos de partida e referências finais da norma jurídica individual a se produzir, torna-se possível vislumbrar alguns prognósticos ${ }^{142}$ que coloquem a mutação constitucional como instrumento importante da aplicação do direito e da evolução da sociedade.

Assim, tendo em vista a prática constitucional e política, acima relatada, ousase, com base nos pressupostos ora utilizados, subtrair uma conclusão que aponte para a caracterização futura do modelo de utilização do instrumento jurídico e veia principal desta dissertação, a saber a mutação constitucional.

Sendo assim, passa-se então a analisar o contexto atual para depois realizar alguns prognósticos a respeito do tema.

\subsection{Do contexto atual}

A Constituição, como visto, a princípio, é modificada pelo procedimento formal de mudança, ou seja, pela aprovação de emendas a seu texto. Para tanto, é necessário se construir uma maioria parlamentar qualificada em torno do assunto, de modo a se alcançar a modificação desejada.

\footnotetext{
${ }^{142}$ No entanto, aqui, mutatis mutandis, cabe a advertência de Norberto Bobbio, quando menciona as palavras de Hegel e Weber na seguinte narrativa: "Em suas lições sobre filosofia da História na Universidade de Berlim, Hegel, respondendo a um estudante que dele queria saber se os Estados Unidos deveriam ser considerados como o país do futuro, assim se manifestou, visivelmente irritado: 'Como país do futuro, a América não me diz respeito. O filósofo não se afina com profecias[...]. A filosofia ocupa-se daquilo que é eternamente, ou melhor, da razão, e com isto já temos muito o que fazer'. Na sua célebre conferência, proferida aos estudantes da universidade de Mônaco no final da guerra, sobre a ciência como vocação, Max Weber assim respondeu aos seus ouvintes que lhe pediam insistentemente um parecer sobre o futuro da Alemanha: 'A cátedra não existe nem para os demagogos nem para os profetas". (BOBBIO, Norberto. O futuro da Democracia. Marco Aurélio Nogueira (Trad). São Paulo: Paz e Terra, 2000. p. 29).
} 
Nesse sentido, uma característica relevante precisa ser ressaltada, que diz respeito ao fato de que as grandes mudanças constitucionais brasileiras sempre estiveram relacionadas a mudanças positivas, ou seja, decorrentes do processo formal de alteração da Constituição, por meio de emendas constitucionais. Já nos Estados Unidos da América, ao contrário, sublinhe-se, as mudanças relevantes sobrevieram a partir do papel central exercido pela Corte constitucional americana naquele país ${ }^{143}$.

O Brasil, contudo, tende a uma aproximação com o modelo americano. Decerto, pois o conteúdo das decisões acerca da união estável homoafetiva, da perda de mandato por infidelidade partidária, da progressão de regime no caso de cometimento de crimes hediondos, da proibição da prisão civil por dívidas, do ordenamento da greve no serviço público e tantas outras, nas quais se vislumbra possam advir a partir do uso indiscriminado do instituto da mutação constitucional, demonstram uma transferência do debate da esfera política para a esfera técnico-jurídica, tal qual parece ser o caso dos Estados Unidos, ainda que não derivadas das mesmas circunstâncias de fato propiciadoras deste cenário.

Todas essas decisões demonstram avanços quanto a conteúdos constitucionais que foram realizados sem a participação do Poder Legislativo ${ }^{144}$, reitere-se.

Pois bem, o debate político institucional brasileiro vem sofrendo certa deterioração e as condições estruturais do sistema político-partidário-eleitoral não contribuem para solidificação de qualquer maioria relevante. Com efeito, os partidos políticos se encontram difusos (há mais de 30 siglas funcionando no país); existe pouco debate programático sobre questões sociais e as pautas econômicas dominam as ações dos governos, de tal modo que questões sobre direitos fundamentais e liberdades individuais são menosprezadas em tais circunstâncias.

\footnotetext{
${ }^{143}$ DAHL, Robert A. How Democratic is the Constitucion? Second Edition. Nova York: Yale University Press, 2003.

${ }^{144}$ Isso sem perder de vista, que, invariavelmente, acontece do legislativo não satisfeito com a decisão judicial modificar o seu conteúdo através do processo formal de reforma, como já o realizou no tema da verticalização das eleições, e no tema, pertinente à interpretação dada pelo STF, quanto ao conceito de população diretamente interessada para efeitos de criação, fusão e incorporação de Municípios, ADI 2650 e EC nº 15/96. E não se pode esquecer dos inúmeros projetos de emenda que, não obstante ainda não tenham sido aprovados, tramitam com o objetivo de superar precedentes vinculantes judiciais, como a não exigência de diploma para o exercício da atividade de jornalista.
} 
Ora, esse ambiente de "desinteresse" por parte do Congresso Nacional, ou mesmo a falta de acordo político sobre determinados assuntos polêmicos, tem preparado um cenário ideal para o desenvolvimento da ação do Poder Judiciário, cuja independência em relação à população e questões marginais é muito mais visível do que nos demais poderes. E, assim, dada a sua independência e consectário afastamento natural das demandas populares e, sobretudo, da sistemática das eleições, temas extremamente difíceis têm sido decididos por ele em detrimento da participação daquele outro, justamente porque, em assim sendo, o Legislativo evita o desgaste natural de se posicionar em relação a temas controvertidos.

Sobre essa questão, trabalho atual do professor da Universidade de Toronto, Ran Hirschl ${ }^{145}$ destaca essa tendência das democracias atuais, sobretudo a dos países periféricos em transferir ao Judiciário os "big cases". É que nestes países, ultrapassada as questões inclusivas do processo decisório como cor, raça, posição social, gênero e renda, as elites estariam descrentes e temerosas acerca do controle possível das decisões legislativas, posto que essas seriam de difícil manipulação. Deveras, já que a democracia contemporânea, dado seu caráter universal, é diametralmente oposta àquela surgida, por exemplo, aqui no Brasil a partir da proclamação da República, no qual as oligarquias reinantes possuíam plena segurança dos efeitos das medidas políticas tomadas e as influenciava diretamente.

Assim, essa transferência do núcleo decisório, ainda que inconsciente, seria um modo de aproximar a decisão dos critérios e da ideologia daqueles que detém o poder social, econômico e político.

Com efeito, se se atenta para os perfis sociográficos dos juízes brasileiros, percebe-se que essa suspeita pode se confirmar, pois os valores se aproximam mais daqueles que sempre estiveram próximos dos centros de decisões do poder, do que daqueles que militam em movimentos sociais, defendendo as causas das ditas minoria.

\footnotetext{
${ }^{145}$ HIRSCHL, Ran. Towards Jusitocracy: The Origins and Consequences of the New Constitucionalism. Cambridge, Massachusetts, and London, England: Harvard University Press, 2007.
} 
Em suma, não se trata de transferir uma decisão política por impulso da sociedade como um todo a um Poder-função específico do Estado. Há uma transferência política por iniciativa de parte desta, daquela que detém o poder. E esta, na falta de uma decisão favorável no parlamento, tem se valido dos tribunais para realizar uma segunda instância de discussão. A esse respeito, veja-se a discussão da ADI $n^{\circ} 4.605$, proposta pelo Conselho Federal da Ordem dos Advogados do Brasil sobre a possibilidade de doações de pessoas jurídicas a campanhas político-eleitorais.

Nesse processo, pagam as sociedades contemporâneas pelo descaso, imobilidade e inércia, já que a transferência do centro de decisão, hipertrofiada por constituições analíticas, a um corpo técnico, possui falhas insuperáveis.

Demais disso, o reconhecimento popular, um tanto quanto paradoxal do valor destes tipos de decisões judiciais e a dificuldade da representação política, como meio capaz de viabilizar a solução dos desacordos públicos dentro de qualquer comunidade, como, fatalmente, sempre tendem a acontecer, parecem legitimar esse tipo de situação.

Contudo, teorias sociológicas à parte, nota-se que o Poder Judiciário tem, sim, sido um reduto de produção de decisões difíceis.

Em outras palavras, na ausência de disciplina expressa quanto a determinados temas, arvora-se o Judiciário o papel, em substituição ao Poder Legislativo, de reconhecer e disciplinar direitos a seu modo sem, a princípio, qualquer responsabilidade quanto à vontade fictícia de qualquer maioria, a não ser aquela necessária para se compor qualquer quorum mínimo de votação no âmbito do próprio Supremo Tribunal Federal.

Logo, diante de tais situações, uma modificação formal relevante da Constituição se mostra algo de difícil alcance, enquanto uma modificação judicial se torna muito mais palpável ${ }^{146}$.

\footnotetext{
${ }^{146}$ Bruce Ackerman em análise das circunstâncias americanas, aponta fenômeno similar: "We are now in the midst of great debates about abortion and religion, about federalism and the war powers of the presidency. But nobody expects a constitutional amendment to resolve any of these issues - instead, we see only symbolic gestures on matters like flag burning and gay marriage. Whatever the future may hold, don't expect big changes through formal amendments. We the People can't seem to crank out messages in the way described by Article V of our Constitution. Our writing machine has gone the way of the typewriter. But why? There are three possibilities: there is something wrong with the ma-chine, something wrong with the American people, or
} 
Ocorre que o Poder Judiciário não tem agido, necessariamente, com fidelidade aos textos normativos ${ }^{147}$, ao contrário, conforme se verá abaixo, seus avanços em muitas ocasiões, ainda que de certa forma aprovados pela maioria da população ${ }^{148}$, conforme pesquisas de dados, realizadas por diversos institutos, afastam-se completamente dos programas normativos, das possibilidades semânticas e dos limites discutidos no bojo do capítulo III deste trabalho.

Nesse contexto, sabe-se que os Ministros do Supremo Tribunal Federal apesar de pouco enfrentarem diretamente o tema da mutação constitucional, em quaisquer de suas modalidades $^{149}$, têm, todavia, reconhecido várias delas, conforme destacado no capítulo II deste trabalho, mediante a atividade ordinária da jurisdição constitucional, sobretudo quando estão em análise temas relacionados à ampliação do alcance de direitos fundamentais.

Nesse diapasão, vê-se que alguns assuntos têm preenchido uma pauta de demandas reprimidas, ou seja, algumas matérias precisam ser enfrentadas para que se proporcionem avanços no processo civilizatório e institucional do Brasil. Assim, necessitam adequado tratamento legislativo as questões eleitorais, inclusive as relacionadas à

nothing wrong with either. Conventional wisdom gives the happy answer: it's a good thing that formal amendment is so hard; otherwise, the Constitution would become a mess, full of details signifying little. The great challenge for constitutional law is to develop historically sensitive categories for understanding these developments. Begin with the idea of an official constitutional canon - the body of texts that conventional legal theory places at the very center of the legal culture's self-understanding. In America today, the official canon is composed of the 1787 Constitution and its subsequent formal amendments. At present, however, there is a yawning gap between this official canon and the nation-centered self-understanding of the American people. The profession has been trying to fill this gap with an operational canon - as I shall call it - that promotes landmark statutes and superprecedents to a central role in constitutional argument. But these attempts have proceeded in an ad hoc fashion, and it is past time for us to reflect on these efforts at adaptation and build an official constitutional canon that is adequate for use by lawyers and judges of the twenty-first century." Ackerman, Bruce. The Living Constitucion. Disponível em $<$ http://www.harvardlawreview.org/issues/120/may07/Lecture_4367.php>. Acesso em 14 de janeiro de 2014.

${ }^{147}$ E aqui cabe o alerta de Dworkin sobre o tema: "um texto, porém, não é apenas uma sequência de letras e espaços: ele é composto de proposições, e não podemos atribuir 'primazia' a um texto - nem, na verdade, qualquer outro lugar hierárquico - sem uma semântica, isto é, sem uma interpretação que especifique o que as letras e os espaços significam [se é que significam algo]. Enquanto não interpretamos as letras e os espaços dessa maneira, não poderemos ter nenhuma ideia do que é ou não 'irreconhecível' com o texto, nem saber se o texto é vago ou ambíguo, nem se pode estar 'sujeito, de modo plausível a interpretações significativamente diferentes'. (DWORKIN, Ronald. A Justiça de Toga. Jefferson Luiz Camargo (Trad). São Paulo: WMF Martins Fontes, 2010. p. 184).

\footnotetext{
${ }^{148}$ Pesquisas realizadas dão conta que a maioria da população é a favor do casamento gay e do aborto de fetos anencéfalos, dois temas que obtiveram tratamento constitucional a partir do julgamento de Ações Diretas de Descumprimento de Preceitos Fundamentais.
}

${ }^{149}$ Veja-se, a respeito, o quanto foi desenvolvido no capítulo I. 
representatividade e disciplina partidária, as questões tributárias, além das questões relativas ao pacto federativo.

Um exemplo de tema esquecido pelas casas legislativas, que incorpora essa demanda reprimida tratada acima, foi a família. Havia lacunas legislativas ${ }^{150}$. Nesse contexto, o Congresso foi incapaz de levar a cabo uma legislação satisfatória a respeito, ainda que impopular. Isto é, a sua inércia abriu espaço para que o Judiciário, provocado por alguns atores, discutisse o tema dentro dos limites que lhe são próprios e oferecesse a resposta tão almejada por todos.

Com efeito, nota-se que nos últimos anos, mesmo sem mudança legislativa profunda expressa, o quanto disposto a respeito no Código Civil de 2002, os Tribunais e, sobretudo o Supremo Tribunal Federal reconheceram novas ressignificações do termo família cuja apreensão não havia dantes sido realizada pelos textos legislativos. E observe-se que a mutação aqui levada a efeito é, particularmente, uma mutação derivada da ação interpretativa do direito em contraponto com a realidade social.

Assim, ao reconhecer as existências de famílias monoparentais e homoafetivas, o Supremo Tribunal Federal buscou, na realidade, uma concretude que se impôs com mais veemência, sobretudo nos últimos dez anos, incorporando ao ordenamento mais uma mudança da Constituição, a qual a legislação ordinária ou mesmo as emendas constitucionais haviam sido incapazes de disciplinar.

\footnotetext{
${ }^{150}$ Neste sentido, apontando lacuna na questão, cumpre atentar para o voto dos Ministros Ricardo Lewandowski, Gilmar Mendes e Cezar Peluso, na ADPF 132, acima mencionada, já que os mesmos, embora reputando as pretensões procedentes (união estável homoafetiva), assentavam a existência de lacuna normativa sobre a questão. O primeiro enfatizou que a relação homoafetiva não configuraria união estável - que impõe gêneros diferentes -, mas forma distinta de entidade familiar, não prevista no rol exemplificativo do art. $226 \mathrm{da} C \mathrm{~F}$. Assim, considerou cabível o mecanismo da integração analógica para que sejam aplicadas às uniões homoafetivas as prescrições legais relativas às uniões estáveis heterossexuais, excluídas aquelas que exijam a diversidade de sexo para o seu exercício, até que o Congresso Nacional the dê tratamento legislativo. O segundo se limitou a reconhecer a existência dessa união por aplicação analógica ou, na falta de outra possibilidade, por interpretação extensiva da cláusula constante do texto constitucional (CF, art. 226, $\S 3^{\circ}$ ), sem se pronunciar sobre outros desdobramentos. Ao salientar que a idéia de opção sexual, estaria contemplada no exercício do direito de liberdade (autodesenvolvimento da personalidade), acenou que a ausência de modelo institucional que permitisse a proteção dos direitos fundamentais em apreço contribuiria para a discriminação. No ponto, ressaltou que a omissão da Corte poderia representar agravamento no quadro de desproteção das minorias, as quais estariam tendo seus direitos lesionados. O Presidente aludiu que a aplicação da analogia decorreria da similitude factual entre a união estável e a homoafetiva, contudo, não incidiriam todas as normas concernentes àquela entidade, porque não se trataria de equiparação. Evidenciou, ainda, que a presente decisão concitaria a manifestação do Poder Legislativo. (informativo de jurisprudência 645 do STF).
} 
Eis, pois, o cenário atual, a saber, um cenário de transição sobre temas eleitorais, civis e políticos ressignificados a partir da atividade de jurisdição constitucional, atuando o Judiciário no vácuo normativo, "prudentemente" ou inficientemente negligenciado pelo Legislativo pois, como afirmado acima, o Judiciário pouco fez para mudar tal estado de coisas.

\subsection{Panorama das mutações constitucionais no Brasil}

Inicialmente, cumpre atentar que com o predomínio da dogmática jurídica, não se nega mais o valor do direito posto, o problema é que o direito posto é, em si, cada vez mais fluído, complexo e extenso. Vide o crescimento do principiologismo e a hipertrofia do valor argumentativo na definição do conteúdo das decisões judiciais e dos textos normativos e, mais precisamente, para a delimitação do conteúdo da própria Constituição.

Essa fluidez de paradigmas e das regras e princípios constitucionais está presente na busca de referenciais mais amplos, elásticos, como a admissão de um bloco de constitucionalidade, o reconhecimento de status diferenciado acerca dos tratados de direitos humanos e a própria doutrina do transconstitucionalismo ${ }^{151}$.

De modo que se enxerga uma supervalorização da argumentação, amparada em uma "superprincipiologia" dos valores morais e jurídicos incertos na Constituição Federal que passam a ser critério primeiro de decisão, ainda que não estejamos diante de casos complexos, que demandam, naturalmente, um esforço argumentativo superior.

A consolidação desse fenômeno fragiliza a previsibilidade, a coerência e a consistência do ordenamento e, por conseguinte, abre demasiado espaço para a admissão de mutações constitucionais desenraizadas de qualquer maior consistência jurisprudencial ou mesmo textual anterior.

\footnotetext{
${ }^{151}$ NEVES, Marcelo. Transconstitucionalismo. São Paulo: WMF Martins Fontes, 2009.
} 
Diferentemente de outrora, não se sabe ao certo como combater os desígnios da nova releitura constitucional, pois, ao contrário do passado, em que se tinha muito bem delimitado o debate entre a posição fixa dos conceitos normativos do direito, seu papel e o consagrado embate mais relevante entre direito natural e positivo, na atualidade, sob o pálio de uma doutrina neoconstitucionalista, esses conceitos acabam por se fundir.

Pois bem, as incoerências e os efeitos decorrentes desta realidade já foram demonstradas acima, ao sublinhar que o Poder Judiciário não representa a vontade da maioria, e também não protege necessariamente a minoria, ele é parte do debate e dá sua opinião a respeito. O problema reside no fato de que sua opinião, sua decisão possui um peso relevante na esfera pública, e como observador e parte da sociedade, sua argumentação, a despeito de técnica, também não foge ao aspecto político.

Nesses termos, essa incessante e crescente atividade judicial ativa tem importado na solidificação de uma tendência de reconstrução e ressignificação jurisprudencial de alguns temas constitucionais, como as questões federativas, fiscais e eleitorais, senão vejamos.

No que concerne a questões eleitorais, veja-se o decidido pelo Tribunal Superior Eleitoral e após sufragado pelo Supremo Tribunal Federal quanto à inelegibilidade de pessoas que viviam uniões estáveis homoafetivas, algo até então não previsto expressamente na legislação (veja o confronto do artigo $14^{\circ}, \S 7^{\circ}$ da Constituição e os Recurso Especial Eleitoral no 24.564 e 54.101.03).

Com efeito, a Constituição não menciona expressamente como causa de inelegibilidade reflexa as uniões estáveis homoafetivas, enquanto que o Tribunal Superior Eleitoral tem-na imputado em tais casos, justamente pelo fato de que o objetivo premente da norma, ainda que, a princípio não extensível a estas uniões, seria burlado, acaso não reconhecida mais essa modalidade de inelegibilidade.

Ora, no caso, o que se quer é afastar a influência política da família no pleito eleitoral, notadamente da família detentora do poder, e não apenas daqueles laços sanguíneos, mas também por afetividade. E assim, nada mais natural que não só os cônjuges sejam atingidos por essa regra, como também aqueles que mantenham união estável, 
independentemente de ser homoafetiva, pois a influência no pleito não distingue sexo, mas sim apenas uma situação de fato.

Daí se vê a mitigação de um direito fundamental de participar do pleito eleitoral por uma interpretação extensiva de preceito constitucional, a partir da conferência de status similar a uma situação de fato, a qual, até bem pouco tempo, qualquer relevância possuía para o direito, como um todo.

Pois bem, outros assuntos ainda necessitam de adequado tratamento, tal como o sistema partidário, pois é notável o esgotamento do modelo atual. No entanto, é evidente que não existe consenso político possível, quanto à sua efetiva mudança. Os detentores da legitimidade para a propositura da Lei a respeito, ou seja, a população, os parlamentares e o Poder Executivo são incapazes de formular uma ideia básica e consensual sobre a profusão de partidos, cláusula de barreira, tempo de exposição de ideias na mídia, meios de financiamento das campanhas políticas ${ }^{152}$, o que acaba por desaguar no dever de decidir do Judiciário.

Nesse diapasão, o financiamento de campanhas políticas tem sido reiteradamente discutido no parlamento, sobretudo no que toca à possibilidade de financiamento público exclusivo ou misto de campanhas eleitorais. Porém, agora, esse debate tem sido redirecionado ao Judiciário, através de uma questão específica que diz respeito a doações para campanhas efetuadas por pessoas jurídicas.

Quanto a essa circunstância, em especial, cumpre destacar que o Congresso Nacional, mediante uma Lei que data do ano de 1993, permitiu a doação de pessoas jurídicas para campanhas políticas, algo ao qual o Conselho Federal da Ordem dos Advogados do Brasil se indispôs a ponto de propor Ação Direta de Inconstitucionalidade, questionando a validade da regra. Trata-se de $\mathrm{ADI} \mathrm{n}^{\mathrm{o}} 4.650$, que já possui quatro votos contrários ao financiamento de campanha mediante aporte de recursos de pessoas jurídicas, sob os argumentos prevalentes de que tal circunstância ataca o processo democrático, criando uma situação de desigualdade, por quem nem sequer detém a capacidade de sufrágio.

\footnotetext{
${ }^{152}$ É bem verdade, contudo, que, recentemente, fora aprovado uma reforma política que dispôs a respeito de uma espécie de cláusula de barreira ou de desempenho a ser imputada aos partidos, dificultando, em certa medida, em caso de não alcançada a meta, o funcionamento partidário, pois se estabelecia critérios diferenciados de acesso ao fundo partidário e tempo de exposição de suas ideias na mídia. O STF, todavia, julgou inconstitucional essas regras. Mas o tema sempre volta a debate e a sociedade não pode se furtar de aprimorar esses mecanismos.
} 
Sendo assim, percebe-se novamente que o Congresso Nacional, por características que lhe são inerentes, possui certa dificuldade com relação a esses temas, como já salientado, tal como ocorreu com relação ao tema da família, pelo qual, diante de grande desacordo político, optou pela inércia perante a realidade que se construía a sua volta ${ }^{153}$.

De outro lado, no que concerne aos temas de natureza fiscal, destaque-se a existência de ações tramitando no Supremo Tribunal Federal, questionando, por exemplo, a extensão da competência tributária da União, no que concerne ao direito de oferecer benefícios fiscais, em prejuízo dos repasses constitucionais destinados às demais unidades federativas (RE 705.423 e RE 572.762).

É que, no contexto de crises econômicas, a União tem se valido da modificação da alíquota de determinados tributos como forma de estimular a produção e o consumo de bens e serviços. Todavia, quando assim age, prejudica-se, concomitantemente, a arrecadação, e, por consequência, os repasses constitucionais direcionados às demais unidades federativas.

Essa aparente irresponsabilidade fiscal tem deixado os demais entes federativos preocupados, pois, por dever constitucional, parte da arrecadação tributária precisa ser direcionada a outros entes, e isso acontece com diversos tributos, inclusive no âmbito estadual em relação ao municipal. Pois bem, à medida que o ente detentor da competência resolve conceder incentivos fiscais, ele acaba por socializar as perdas de arrecadação daí advindas, sem, no mais das vezes, construir essa decisão com os demais afetados.

Uma decisão eventual do Supremo Tribunal Federal no sentido da proibição de tal prática pode inaugurar um novo sentimento federativo, bem como demonstrar mais uma vez uma guinada no entender e interpretar a Constituição, esse organismo vivo de feição

\footnotetext{
${ }^{153}$ Mas, não se pode acusar o Congresso de inércia, assim tão simplesmente. É que, o Congresso aprovou cláusula de desempenho para os partidos em período recentes e ainda disciplinou suficientemente o financiamento de campanhas. Quanto ao casamento entre pessoas do mesmo sexo, igualmente no âmbito do Código Civil de 2002, preferiu, apesar de assim poder fazer, não reconhecer alguns avanços/novidades, com relação ao tema. Daí se ver, que não se trata propriamente de uma omissão, inércia pura, pela negativa de debate ou de discussão desses temas nas comissões respectivas, mas sim de um desejo na manutenção do estado vigente. E aí, passamos a ter um problema de ordem política, pois se quer misturar funções sob o argumento valorativo, e tudo isso, por alguém que não foi eleito para tal mister, mas apenas dominaria um saber necessário para "melhor" tratar o tema, , afinal como pontuou Canotilho, "a jurisdição constitucional não é propriamente uma atividade política sob vestes jurídicas" (CANOTILHO, José Joaquim Gomes. Direito Constitucional. $6^{\mathrm{a}}$ ed. Coimbra: Livraria Almedina, 1993. p. 36-7).
} 
institucional. Sobretudo, tendo em vista que uma mudança legislativa, nesse sentido, tem pouca chance de ser efetivada, já que o parlamento, a despeito de representativo de toda a população ou mesmo dos Estados brasileiros, seria incapaz de construir uma maioria nesse sentido, ante a grande influência que exerce o Poder Executivo Federal sobre o Congresso brasileiro.

Por fim, outro tema que também tem dominado a pauta do Tribunal e demonstra potencial para passar por modificações de origem judicial é o Federalismo.

Ora, sabe-se que o Brasil é uma República Federativa inspirada no modelo americano e desenhada em sua origem por Rui Barbosa, na Constituição de 1889, promulgada por ocasião da Proclamação da República. Sem adentrar em temas específicos quanto à simetria ou assimetria de nosso federalismo, o fato é que, em terras tupiniquins, o instituto, dadas as circunstâncias aqui presentes, assumiu caráter próprio ${ }^{154}$.

Com efeito, passados mais de cem anos, as instituições ainda necessitam entender e disciplinar o alcance da ideia federalista no país. Na atualidade, a concentração sempre vigente entre nós tem sido posta em xeque, e os Estados conclamam um novo pacto entre a unidade central, no caso, a União, e as unidades descentralizadas, Estados e Municípios.

Nesse sentido, colhe-se na jurisprudência do Supremo Tribunal Federal uma supervalorização do princípio da simetria, que importa em tornar a estruturação dos Estados repetições do modelo encartado na Constituição no tocante ao órgão central.

Desse modo, o STF sufoca as autonomias estaduais, veja-se a respeito, o quanto decidido na ADI $n^{\circ}$ 2.872-PI, na qual restou declarada a inconstitucionalidade de norma proveniente do poder constituinte derivado, a qual exigia a necessidade de lei complementar para disciplinar matéria relativa a servidor público, em oposição à Constituição Federal que a respeito exige tão somente a necessidade de lei ordinária.

\footnotetext{
${ }^{154}$ O Supremo Tribunal Federal, tradicionalmente, tem-se apegado ao modelo centralizado de nossa federação, talvez, até por razões históricas, já que nosso modelo se afasta do modelo estadunidense de federação, ao passo em que lá, havia um sentimento separatista, que se converteu em uma união, mas com a mantença de determinadas prerrogativas, já aqui a centralização foi necessária como modo de evitar uma separação e dissolução do Estado brasileiro.
} 
Trata-se de simples disciplina normativa dos recursos humanos de cada unidade federativa, cuja organização se dará mediante um instrumento normativo em detrimento de outro, que foi o escolhido pela União. Ora, será legítimo obrigar as unidades descentralizadas a repetirem em suas realidades o mesmo modelo, ainda que tal tema, em si, não represente qualquer maior relevância institucional?

Bem, igual sufocamento da autonomia estadual, e, coincidentemente, em matéria pertinente aos servidores públicos, colhe-se na decisão derivada do julgamento da ADI $n^{\circ}$ 4.696-PI, que de forma idêntica, contudo, ainda que em sede liminar, proibiu ao legislador constituinte estadual de estabelecer como limite para aposentadoria compulsória de seus servidores, a idade de 75 (setenta e cinco) anos, ao invés dos 70 anos, conforme disposto no texto magno federal.

Aqui, novamente, sublinha-se, será que a Federação não comportaria uma margem de autonomia para a definição deste tema específico, ainda que outras unidades dispusessem de modo diferente? A federação se torna frágil em razão da aposentadoria tardia de um servidor em uma unidade e não em outra? É necessário que haja essa uniformidade?

Como se vê, tradicionalmente, o olhar para o Estado membro sempre foi restritivo. Entretanto, recentemente, os Ministros dão mostras de modificação deste panorama e as interpretações têm caminhado no sentido do fortalecimento das autonomias estaduais, notadamente, quando se está diante da interpretação de normas de observância, repetição obrigatória pelo Estado membro. E, destaque-se, sempre agindo o STF no vácuo normativo, pois o Congresso, em termo de federalismo, sobretudo, nada de relevante tem feito nas últimas legislaturas.

No passado, e até recentemente, dado o caráter analítico de nossa Constituição, sempre se pensou no Estado membro como um ente "incapacitado" para oferecer soluções plausíveis a questões constitucionais que não houvessem sido pensadas pelo documento central, como visto acima. Já hoje, tal orientação parece passar por forte mudança de sentido.

Deveras, e já se nota essa realidade no caso da escolha de delegados para chefiar a instituição no Estado de Goiás (ADI n ${ }^{0}$ 3.062). Em oposição ao que já se decidiu outrora, $\mathrm{ADI} \mathrm{n}^{\mathrm{o}}$ 132, o Supremo mudou a orientação quanto à regra de escolha do delegado 
geral do Estado membro, assentando expressamente a busca por privilegiar modelos locais que não confrontassem diretamente com a escolha central. Tal movimento importa na reconstrução jurisdicional da própria teoria do federalismo, afastando anterior subordinação dos Estados-membros e dos Municípios ao denominado standard federal tão excessivamente centralizado da CF/69, como consignaram os Ministros Gilmar Ferreira Mendes e Ayres Britto em seus respectivos votos.

No mesmo sentido, vemos o financiamento dos entes da federação decorrentes da participação em valores derivados da exploração de recursos naturais. Nesta última, assistimos ao embate pelo qual se passou, inicialmente, no Congresso e, após, no Supremo Tribunal Federal, acerca da repartição das receitas decorrentes da exploração de Petróleo em bens de propriedade da União, no caso, a serem apropriados por todos os entes da federação.

Tal qual já enunciado, os Estados precisam de recursos para manter as respectivas estruturas, bem como promover os serviços públicos que lhe são acometidos. Neste ínterim, note-se que estes possuem uma escala de financiamento relativamente diminuta, pois a maioria das competências tributárias e de exploração de recursos naturais, bem como a atividade empresarial, estão, quase que na totalidade concentradas no âmbito da União que, a despeito de representar a união dos demais entes federativos, acaba por atuar com um ente independente, com interesses contrapostos, e que em nada contribuem para a solidificação de um sentimento realmente federativo.

Portanto, temas como financiamento público de campanha, isenções de impostos, guerra fiscal, fidelidade partidária, financiamento de partidos políticos, foram de uma forma ou de outra, judicializados. E essa judicialização pode levar a fenômenos mutacionais relevantes, não tão legítimos do ponto de vista majoritário, mas que se imporão, com base exclusiva na força de um Poder e da legitimidade do exercício da jurisdição constitucional. E como estamos diante de textos normativos, demasiadamente analíticos ou propositadamente abertos, nada mais natural do que serem sindicados por uma Corte Judicial, como o Supremo Tribunal Federal.

Dito isto, não nos causará espécie que a nova conformação institucional brasileira seja gestada em gabinetes, supostamente técnicos de magistrados, que sob o pretexto de prevalência da norma constitucional, construam novos arquétipos, políticos, 
federativos, eleitorais que mudem radicalmente a distribuição de Poder e o seu exercício, sem que haja sobre tais conteúdos qualquer controle adicional por parte dos demais atores deste universo democrático aqui instalado.

Nesse sentido, pululam projetos de súmula vinculante com o único desiderato de estabelecer novos deveres ao Estado, que bem poderiam ser mediados pelo legislativo, mas que acabarão sendo conformados em decisões judiciais.

Nesses termos, veja-se o projeto súmula vinculante $n^{\circ} 4 / 2008$, da Defensoria Pública da União, cujo objetivo é estabelecer

A responsabilidade solidária dos Entes Federativos no que concerne ao fornecimento de medicamentos e tratamento médico ao carente, comprovada a necessidade do fármaco ou da intervenção médica, restando afastada, por outro lado, a alegação de ilegitimidade passiva corriqueira por parte das Pessoas Jurídicas e Direito Público [e ainda, questão mais tormentosa] a possibilidade de bloqueio de valores públicos para o fornecimento de medicamento e tratamento médico ao carente, comprovada a necessidade.

Ora, afastando-se a alegação de que tal bloqueio fere o quanto prescrito no caput do art. 100, $\S 2^{\circ}$ da Constituição, nota-se, no excerto, o típico desejo de se mudar a Constituição, sem que se submeta a um processo político formal, tipificado no texto constitucional $^{155}$, possivelmente porque uma providência nesse sentido dificilmente alcançaria o apoio necessário para aprovação.

Isto posto, resta-nos aguardar e apontar as incongruências que se ramificam a partir deste modelo e que tem na mutação constitucional o seu principal produto. No entanto, se como aqui apontado, a jurisprudência passar a dar mais valor à atividade de superação de seus precedentes que aos pontos de partida postos e ainda à coerência e consistência das decisões, podemos assistir a mutações realmente reflexas da sociedade, e não puramente da doutrina jurídica esboçada nas decisões das cortes brasileiras sem qualquer maior apelo ou enraizamento no tecido social.

\footnotetext{
${ }^{155}$ Mencionado projeto de súmula está sobrestado aguardando o julgamento do $\mathrm{RE} \mathrm{n}^{\mathrm{o}} 566.471 / \mathrm{RN}$, o qual teve a repercussão geral reconhecida, e no qual se discute a obrigatoriedade do Poder Público fornecer medicamentos de alto custo.
} 


\section{CONCLUSÃO}

A Constituição, como ápice da pirâmide jurídica, conforme o modelo Kelseniano, positivista, de apelo à lógica formal, adotado em certa medida com as devidas nuances ao longo desta pesquisa, sujeita-se a mudanças, as quais, em algumas oportunidades, afastam-se de processos específicos e formais de reforma, trazendo em si, uma determinada situação que importa na interpretação criativa de preceitos normativos.

Trata-se, em síntese, da colmatação entre norma e realidade pela atividade não legislativa de aplicação do direito.

Sabe-se que o objetivo da interpretação é chegar ao resultado constitucionalmente 'correto' através de um procedimento racional e controlável. E esse resultado não comporta dilações que extrapolem os sentidos semânticos dos textos normativos, sob pena de, em um determinado momento, estarmos assistindo a uma verdadeira reforma constitucional derivada dos tribunais, sem nenhuma base popular e, o que é mais grave, sem amparo constitucional.

Como restou exposto no trabalho, cabe observar que muitos doutrinadores, dentre eles, Hans Kelsen duvidam do caráter científico da intepretação jurídica, o que nos faz pensar que a mediação entre texto abstrato e norma individual é realizada por ato, não jurídico, mas derivado de outros fatores, cuja preponderância política pode dificultar a autonomia do próprio direito, como ciência puramente isolada dos demais subsistemas sociais.

Assim empreendendo, acabamos por nos centrar sobre um debate interminável, acerca do que seja o direito e do valor da interpretação para a sua descoberta e/ou aplicação.

É que, segundo a Dogmática Jurídica, tanto a lei, quanto as normas, quanto a jurisprudência, são dados que podemos considerar apenas como parte do direito. Decerto, a própria lei em si, ao destacar determinado fato da vida e o regulamentar já diz muita coisa sobre sua compreensão e aplicação. E como parte e preceito inicial e inegável, tais dados possuem importância ímpar, no descobrimento da norma jurídica "final", ou seja, daquela que 
servirá para efeitos de solução da lide, de produção de novas normas, ou de margem para interpretação de seu conteúdo, sem que haja, contudo, a princípio, qualquer grau diferenciado de importância entre eles.

Nesses termos, podemos assumir, todavia, em uma solução conciliatória, no entanto não menos científica em seu caráter, que a interpretação é parte da política, porém, igualmente parte da ciência do direito.

E sendo assim, não se pode negar que existe uma zona política no processo de interpretação do direito, mas isso não pode significar a admissão do arbítrio do magistrado no processo de conhecimento das demandas judiciais, notadamente, quando se originarem de temas afeitos às decisões acerca de políticas públicas e outros debates nacionais cujo assento, segundo a concepção de democracia aqui exposta, melhor se contém na mediação legislativa, ou mesmo em mecanismos de democracia direta.

Peter Häberle, já mencionado neste trabalho, afirma que não existe norma jurídica e sim norma interpretada, de modo que o conceito relevante de direito se transfere da norma propriamente dita para a atividade jurisdicional, portanto interpretativa. Pois bem, se a mutação não é norma, ela só poderia ser interpretação, e se ela se confunde com interpretação, apesar de direito, não faria sentido todo um esforço teórico para se deter em apenas um aspecto da interpretação.

Contudo, a despeito de não se negar o quanto de interpretação é necessário para o reconhecimento de qualquer direito, inclusive de uma mutação, a valoração da norma posta se justifica pelas particularidades citadas no capítulo I e, sobretudo, pelo grande serviço que tal ideal presta aos cânones da segurança jurídica e ao instituto da democracia.

Logo, nesse contexto, nada mais natural que se dar maior peso ao direito posto, ainda que este, em seu processo de formação, não reflita, necessariamente, a norma mais justa. É que, como sabido, essa injustiça pode ser repelida ao longo do processo pela interpretação e compreensão das demais normas que compõem o ordenamento jurídico. Já a injustiça de uma decisão arbitrária, individualista e pouco responsiva quanto aos textos normativos, apenas possui as normas processuais como defesa. 
Como visto, é impossível despir a interpretação, sobretudo a do texto constitucional, do caráter criativo ${ }^{156}$ que lhe é ínsito. Por consequência, vemos que tal interpretação criativa acaba por gerar uma mudança no programa normativo do texto constitucional. Essa mudança nem sempre é bem recebida pela comunidade. A bem da verdade, o que há, na maioria dos casos, é justamente uma falha no canal referente à motivação dessas mudanças, já que o processo se mostra obscuro, perdido no universo de argumentações jurídicas ineficientes e pouco controláveis.

Nesse sentido, a despeito de aqui não se negar uma determinada reserva criativa do processo de intepretação das normas jurídicas, notadamente das normas constitucionais, faz-se necessário, diante do diálogo do texto constitucional com a realidade, a observância do princípio da razoabilidade e do da proporcionalidade nas decisões judiciais, assim como um respeito aos precedentes jurisprudenciais e postulados democráticos, tudo dentro de um procedimento argumentativo cujo referencial maior há de ser o direito posto, nos termos assentados no capítulo III.

Com efeito, a mutação constitucional, por se centrar no texto e se afastar de um processo formal de mudança, possui determinadas características, limites e fatores de legitimidade, como visto no capítulo III, que ajudam a manter o processo de jurisdição constitucional responsivo em relação ao direito posto, ao direito representativo da vontade popular, com todas as reservas a que esta expressão pode nos remeter.

Dito de outro modo, tais mudanças precisam estar acordes, com três institutos básicos, a saber, o princípio democrático, a jurisprudência consolidada, e, sobretudo, o texto constitucional, haja vista que a decisão porventura advinda deve ser objeto de uma análise de distinção, aos moldes de superação de precedente de países que adotam o commom law, e ainda pode ser reconduzida ao texto, apartando deste universo decisões que põem terra ao texto e tornam este atuar ilegítimo e, por consequência, inconstitucional. Isto é, a mutação deve respeito ao texto normativo e à norma então produzida, numa espécie de moldura, naquele âmbito de possibilidade de alcance de uma norma, sendo essa decisão condicionada por fatores anteriores, como a integridade da jurisprudência e os valores da democracia.

\footnotetext{
${ }^{156}$ HABERMAS, Jürgen. Direito e Democracia: entre facticidade e validade. $2^{\mathrm{a}}$ edição. Flávio Beno Siebeneichler (Trad.). Rio de Janeiro: Tempo Brasileiro, 2010. p. 305-6. Vol. 1.
} 
Segundo Konrad Hesse ${ }^{157}$, “embora o Tribunal seja competente para fixar esse conteúdo (das normas constitucionais) com eficácia vinculante, nem por isso ele está acima da Constituição, à qual deve sua existência”.

Todavia, sabe-se que o texto legal puro e simplesmente é insuficiente para pautar a decisão de um caso concreto ou mesmo a análise abstrata de uma norma perante a Constituição, pois se faz necessário conviver com elementos imponderáveis neste contexto.

Tal conjuntura nos tem impelido a agir com esmero quanto ao processo hermenêutico. Com efeito, posto que as respostas hão de ser dadas não só pelo processo legiferante regular, como também a partir da interpretação dos textos normativos, já que o texto em si, e as possibilidades normativas de então não serão mais suficientes diante de situações excepcionais.

Diante disso, faz-se importante entender o processo hermenêutico e a legitimidade democrática da atuação judicial, não só perante omissões legislativas, ditas puras, referente ao descompasso entre programa normativo e realidade, mas também na ausência dessa desconformidade.

Ou seja, na hipótese de suposta "inércia qualificada", a saber, aquela que não representa um puro não legislar quando se devia fazê-lo, por disposição expressa da Constituição ou da lei, mas sim, um não legislar, não realizado, justamente, pelo fato de a matéria ainda não se encontrar suficientemente permeabilizada e amadurecida nas casas legislativas. Trata-se da hipótese em que se nega regulamentação, ou reconhecimento de um direito, justamente porque o legislador assim não consente.

Essa inércia do Legislativo acaba por militar em seu desfavor e abrir espaço para outras instituições não tão legitimadas pelo corpo da população e pelos processos representativos de decisão quanto o Congresso, a impor contornos particulares sobre determinados fatos da vida social, a exemplo da recente regulamentação do direito de greve do servidor público pelo Supremo Tribunal Federal.

\footnotetext{
${ }^{157}$ HESSE, Konrad. Limites da Mutação Constitucional. Temas Fundamentais do Direito Constitucional. Inocêncio Mártires Coelho (Trad.). São Paulo: Saraiva, 2009. p. 22.
} 
E normas incompletas, por sua vez, carentes de concretização, abertas a interpretações elásticas ajudam a explicar a mutação, pois tais fatores são um convite à desnecessidade de uma reforma formal do texto constitucional, e possibilitam ao intérprete mudar o sentido do texto, da jurisprudência, sem que seja necessária a participação do parlamento neste processo. Todavia, essa atuação não é pura e livre de condicionantes da realidade, e sim limitada.

Pois bem, a hipótese proposta neste trabalho partiu da premissa de que a jurisdição constitucional é legítima e, como decorrência, também a mutação constitucional que, em certa medida, é um desdobramento hermenêutico da aplicação, criação e atualização do direito. Outrossim, também se determinou, a priori, que a Constituição não se restringe apenas a seu texto positivo. Sendo fato que ele é apenas um ponto de partida importante, mas sua delimitação é essencial no processo de formação da norma individual, e outros fatores ainda podem influenciar esse procedimento, como os princípios, sejam eles positivados ou não, o costume, a ideia de bloco de constitucionalidade, as normas internacionais, além dos precedentes jurisprudenciais.

A grande questão, pois, diante disso tudo, é saber, nos termos de um conceito atual de Constituição e das necessidades da modernidade, qual a maneira segura de atuação das instituições, no caso, do Poder Judiciário, notadamente quando realiza a sua função precípua que diz respeito à interpretação das normas jurídicas e tudo o que isso pode trazer de mudança na sociedade e na sua relação com o Estado. Já que, na ausência de um desenvolvimento científico desta correlação, peca-se por, primeiro, supervalorizar a interpretação da norma, do seu conteúdo em relação a sua tradição, seu significado, sua prática e padrão semântico. E, segundo, por menosprezar a função de representatividade do direito posto.

Neste diapasão, pensa-se ter alcançado esse objetivo ao bem delimitar a mutação constitucional neste universo e trazer a democracia, o texto e a jurisprudência como grandes anteparos da segurança jurídica neste universo tão complexo de embate entre normatividade e realidade circundante.

Desse modo a mutação constitucional evita, em última instância, por um lado, o imobilismo do direito perante as mudanças da sociedade e por outro, desde que respeitado 
os seus limites possíveis, o crescimento desgovernado de um julgamento por equidade, extremamente pernicioso a qualquer ideia de igualdade vigente sob qualquer rincão democrático.

Portanto, para que exista estabilidade e diálogo da Constituição com seu tempo, há de haver respeito aos direitos e segurança jurídica, fazendo-se necessário para tanto que haja sustentabilidade das decisões e observância das opções legislativas ${ }^{158}$ e democráticas, sob pena de se atribuir ao Judiciário um papel proeminente que tende a romper em favor deste, o equilíbrio entre os poderes, ainda que esta ideia hoje não represente mais a clássica visão do barão de Montesquieu ${ }^{159}$ e 160 . Assim cabe ao Juiz um papel de maior comedimento neste processo, ainda que parte da doutrina enxergue na Constituição de 1988 um convite a uma atitude mais ativista diante da realidade e dos preceitos constitucionais postos.

\footnotetext{
${ }^{158}$ WALDRON, Jeremy. A Dignidade da Legislação. Luis Carlos Borges (Trad.). São Paulo: Martins Fontes, 2003. p.5.

159 “E mesmo os mais legalistas e partidários de uma clara separação de poderes reconhecem que esse princípio não pode ser mais compreendido como queria Montesquieu. O que tanto mudou? Basicamente, os três aspectos do mesmo fenômeno, colocados no título desta introdução (generalidade da lei, criação do direito pelo judiciário e dissociação entre texto e norma), que irão interferir decisivamente tanto no direito quanto na política" (ADEODATO, João Maurício. A Retórica Constitucional: sobre tolerância, direitos humanos e outros fundamentos éticos do direito positivo. São Paulo: Saraiva, 2009. p.172).
}

160 "Há em cada Estado três espécies de poder: o poder legislativo, o poder executivo das coisas que dependem do direito das gentes, e o poder executivo daquelas que dependem do direito civil. [...] Quando em uma só pessoa, ou em um mesmo corpo de magistratura, o poder legislativo está reunido ao poder executivo, não pode existir liberdade, pois se poderá temer que o mesmo monarca ou o mesmo senado criem leis tirânicas para executá-las tiranicamente. Também não haverá liberdade se o poder de julgar não estiver separado do poder legislativo e do executivo. Se o poder executivo estiver unido ao poder legislativo, o poder sobre a vida e a liberdade dos cidadãos seria arbitrário, pois o juiz seria o legislador. E se estiver ligado ao poder executivo, o juiz poderia ter a força de um opressor". (MONTESQUIEU. Do Espirito das Leis. Tradução de Jean Melville. São Paulo: Mantin Claret, 2002. p. 165-166). 


\section{REFERÊNCIAS}

ABRAMOVICH, Victor; COURTIS, Christian. Los Derechos sociales como derechos exigibles. Madrid: Editorial Trotta, 2002.

ACKERMAN, Bruce. The Living Constitucion. Disponível em $<$ http://www.harvardlawreview.org/issues/120/may07/Lecture_4367.php>. Acesso em 14 de janeiro de 2014

ADEODATO, João Maurício. A Retórica Constitucional: sobre tolerância, direitos humanos e outros fundamentos éticos do direito positivo. São Paulo: Saraiva, 2009.

. Filosofia do Direito: uma crítica à verdade na ética e na ciência. São Paulo: Saraiva, 2002.

ALEXY, Robert. O conceito e validade do direito. Gercélia Batista de Oliveira Mendes (Trad.). São Paulo: WMF Martins Fontes, 2009.

ALMEIDA, Alberto. A cabeça do brasileiro. São Paulo: Record, 2009.

ÁVILA, Humberto (2011). Segurança Jurídica: Entre permanência, mudança e realização no Direito Tributário. São Paulo: Malheiros Editores, 2011.

AZAMBUJA, Darcy. Teoria Geral do Estado. 27ª ed. Rio de Janeiro: Globo, 1988.

BARAK, Aharon. The Judge in a Democracy. New Jersey, Princeton University Press, 2006.

BARROS. Sérgio Resende de. Constituição, artigo 52, inciso X: reversibilidade in Revista de Informação Legislativa. Ano 40, nº 158, Brasília: Senado Federal, 2003.

BARROSO, Luís Roberto. Mutação Constitucional. In GONÇALVES JÚNIOR, Jerson Carneiro; BETTINI, Lúcia Elena Polletti; MOREIRA, Eduardo Ribeiro (orgs). Hermenêutica 
Constitucional - homenagem aos 22 anos do Grupo de Estudo Maria Garcia. Florianópolis: Conceito Editorial, 2010.

- Curso de Direito Constitucional Contemporâneo: os conceitos fundamentais e a construção do novo modelo. São Paulo: Saraiva, 2009.

BASTOS, Celso Ribeiro; MEYER-PFLUG, Samantha. In SILVA, Virgílio Afonso da (org). Interpretação Constitucional. São Paulo: Malheiros, 2007.

. Hermenêutica e Interpretação Constitucional. $3^{\mathrm{a}}$ ed. São Paulo: Celso Bastos Editor, 2002

BARZOTTO, Luis Fernando. A democracia na Constituição. Porto Alegre: Editora Unisinos, 2005.

BAUMAN, Zygmunt. Medo Líquido. Carlos Alberto Medeiros (Trad.). Rio de Janeiro: Zahar, 2008.

. Tempos Líquidos. Carlos Alberto Medeiros (Trad.). Rio de Janeiro: Zahar, 2007.

. Modernidade Líquida. Plínio Dentzien (Trad.). Rio de Janeiro: Zahar, 2001.

BECK, Ulrich. Sociedade de Risco: rumo a uma outra modernidade. $2^{\mathrm{a}}$ ed. Sebastião Nascimento (Trad.). São Paulo: Editora 34, 2011.

BINENBOJM, Gustavo. A Nova Jurisdição Constitucional Brasileira - Legitimidade democrática e instrumento de realização. $3^{a}$ edição. Rio de Janeiro: Renovar, 2010.

BOBBIO, Norberto. O futuro da Democracia. Marco Aurélio Nogueira (Trad). São Paulo: Paz e Terra, 2000.

. O Positivismo Jurídico: Lições de filosofia do Direito. Márcio Pugliesi; Edson Bonie; Carlos E. Rodrigues (Trads). São Paulo: Ícone, 1995. 
BONAVIDES, Paulo. Curso de Direito Constitucional. $13^{\mathrm{a}}$ ed. São Paulo: Malheiros Editores, 2003.

CANOTILHO, José Joaquim Gomes. Direito Constitucional. $6^{\mathrm{a}}$ ed. Coimbra: Livraria Almedina, 1993.

CAPELLER, Nanda de Lemos. Fênix e o eterno retorno: a dialética entre a imaginação sociológica e a força do Estado. Lições de Direito Alternativo.

CAPPELLETTI, Mauro. Juizes Legisladores? Carlos Alberto Alvaro de Oliveira (Trad.). Porto Alegre: Sergio Antônio Fabris Editor, 1993.

COELHO, Inocêncio Mártires. Interpretação Constitucional. 4ª ed. São Paulo: Saraiva, 2011.

COMPARATO, Fábio Konder. A Afirmação Histórica dos Direitos Humanos. $7^{\mathrm{a}}$ ed. São Paulo: Saraiva, 2010.

DAHL, Robert A. How Democratic is the Constitucion? Second Edition. Nova Yoork: Yale University Press, 2003.

DAU-LIN, Hsü. Mutación de La Constitución. Pablo Lucas Verdú e Christian Förster (Trads). Oñati: IVAP, 1998.

DIMOULIS, Dimitri. Positivismo Jurídico: Introducão a uma teoria do direito e defesa do pragmatismo jurídico-político. São Paulo: Método, 2006.

DWORKIN, Ronald. A Justiça de Toga. Jefferson Luiz Camargo (Trad). São Paulo: WMF Martins Fontes, 2010.

. O Império do Direito. Jefferson Luiz Camargo (Trad.). $2^{\mathrm{a}}$ ed. São Paulo: Martins Fontes, 2007.

- O Direito da Liberdade: A Leitura moral da Constituição norte-americana. Marcelo Brandão Cipolla (Trad.). São Paulo: Martins Fontes, 2006. 
FERRAZ, Anna Cândida da Cunha. Mutação, Reforma e Revisão de Normas Constitucionais. Revista dos Tribunais, ano 2, n. 5, p. 17, out/dez. 1993. Cadernos de Direito Constitucional e Ciência Política.

FERRAZ JÚNIOR, Tércio Sampaio. Introdução ao Estudo do Direito: técnica, decisão, dominação. $4^{\mathrm{a}}$ ed. São Paulo: Atlas, 2003.

FERREIRA FILHO, Manoel Gonçalves. Aspectos do Direito Constitucional Contemporâneo. $2^{\mathrm{a}}$. ed. São Paulo: Saraiva, 2009.

GOMES, Laurentino. 1808: como uma rainha louca, um príncipe medroso e uma corte corrupta enganaram Napoleão e mudaram a história de Portugal e do Brasil. São Paulo: Planeta do Brasil, 2007.

GRAU, Eros Roberto. $O$ direito posto e o direito pressuposto. $7^{\mathrm{a}}$ ed. São Paulo: Malheiros, 2008.

GRIMM, Dieter. Constituição e Política. Geraldo de Carvalho (Trad). Belo Horizonte: Del Rey, 2006.

HÄBERLE, Peter. Zeit und Verfassung. IN: Probleme der Verfassungsinterpretation, org: Dreier, Ralf/Schwegmann, Friedrich, Nomos, Baden-Baden, 1976, p. 312-313.

A jurisdição constitucional na sociedade aberta. In TAVARES, André Ramos; LEITE, George Salomão; SARLET, Ingo (orgs). Estado constitucional e organização do poder. São Paulo: Saraiva, 2010.

HABERMAS, Jürgen. Direito e Democracia: entre facticidade e validade. $2^{\mathrm{a}}$ edição. Flávio Beno Siebeneichler (Trad.). Rio de Janeiro: Tempo Brasileiro, 2010. Vol. 1.

HESSE, Konrad. Limites da Mutação Constitucional. Temas Fundamentais do Direito Constitucional. Inocêncio Mártires Coelho (Trad.). São Paulo: Saraiva, 2009 
A força normativa da Constituição. Gilmar Ferreira Mendes (Trad.). Porto Alegre: Sérgio Antonio Fabris Editor, 1991.

HIRSCHL, Ran. Towards Jusitocracy: The Origins and Consequences of the New Constitucionalism. Cambridge, Massachusetts, and London, England: Harvard University Press, 2007.

IANNI, Octávio. Raças e classes sociais no Brasil. $2^{\mathrm{a}}$ ed. Rio de Janeiro: Civilização Brasileira, 1972.

JELLINEK, G. Reforma y Mutacion de la Constitucion. Christian Förster (Trad.). Centro de Estudios Constitucionales, Madrid, 1991.

KELSEN, Hans. Teoria Pura do Direito. $6^{\text {a }}$ edição. João Baptista Machado (Trad.). Coimbra: Armínio Amado, 2003.

. A democracia. Ivone Castilho Benedetti e outros (Trad.). São Paulo: Martins Fontes, 2000.

LARENZ, Karl. Metodologia da Ciência do Direito. $3^{\text {a }}$ ed. Lisboa,1997.

LASSALE, Ferdinand. A Essência da Constituição. $9^{\text {a }}$ edição. Rio de Janeiro: Lumen Juris, 2010

LEAL, Roger Stielfelmann. O efeito vinculante na jurisdição Constitucional. São Paulo: Saraiva, 2006.

LUHMANN, Niklas. Sociologia do Direito I. Gustavo Bayer (Trad.). Rio de Janeiro: Edições Tempo Brasileiro, 1983.

MARINONI, Luiz Guilherme. Juiz não pode decidir diferente dos tribunais. Disponível em $<$ http://www.conjur.com.br/2009-jun-28/juiz-nao-direito-decidir-diferente-tribunaissuperiores>. Acesso em 26.06.2009. 
MARTINS, Leonardo. Igualdade e Liberdade na Justiça Constitucional. In TAVARES, André Ramos; LEITE, George Salomão; SARLET, Ingo Wolfgang (orgs). Estado Constitucional e organização do Poder.. São Paulo: Saraiva, 2010.

MENDES, Gilmar Ferreira. Jurisdição Constitucional- 2002 -2010. São Paulo: Saraiva, 2012.

MEZZAROBA, Orides e Monteiro, Claudia Servilha (2003). Manual da Metodologia da Pesquisa no Direito. São Paulo: Saraiva.

MONTESQUIEU. Do Espírito das Leis. Tradução de Jean Melville. São Paulo: Mantin Claret, 2002.

MÜLLER, Friedrich. O Novo Paradigma do Direito: introdução à teoria e metódica estruturante. $3^{\mathrm{a}}$ edição revista, atualizada e ampliada. São Paulo: Editora Revista dos Tribunais, 2013.

NEVES, Marcelo. Entre hidra e Hércules: princípios e regras constitucionais como diferença paradoxal do sistema jurídico. São Paulo: WMF Martins Fontes, 2013.

. Constituição Simbólica. São Paulo: WMF Martins Fontes, 2011.

. A Constitucionalização Simbólica. São Paulo: WMF Martins Fontes, 2007.

. Transconstitucionalismo. São Paulo: WMF Martins Fontes, 2009.

. Entre Têmis e Leviatã: uma relação difícil: o Estado Democrático de Direito a partir e além de Luhmann e Habermas. São Paulo, 2006 (tradução nossa).

. Constitucionalização simbólica e desconstitucionalização fática: mudança simbólica da Constituição e permanência das estruturas reais de poder. Revista de Informação Legislativa, Brasília, ano 33, n. 132, p. 323, out/dez 1996.

RAMOS, Elival da Silva. Controle de Constitucionalidade no Brasil: perspectivas de evolução. São Paulo, Saraiva, 2010. 
. Ativismo Judicial: Parâmetros Dogmáticos. São Paulo: Saraiva, 2010.

- Parâmetros Dogmáticos do Ativismo Judicial em Matéria Constitucional. Tese apresentada à Faculdade de Direito da Universidade de São Paulo, para inscrição em concurso público visando ao provimento de cargo de Professor Titular, junto ao Departamento de Direito do Estado - área de Direito Constitucional, São Paulo, 2009.

. Controle Jurisdicional de Políticas Públicas. São Paulo: Revista da Faculdade de Direito, 2007.

RAWLS, John (1971). O Liberalismo Político. Álvaro de Vita (Trad.). São Paulo: WMF Martins Fontes, 2011.

RAZ, Joseph. O Conceito de Sistema Jurídico: uma introdução à teoria dos sistemas jurídicos. Maria Cecília de Almeida (Trad.); revisão de tradução de Marcelo Brandão Cipolla. São Paulo: Martins Fontes, 2012.

ROSSEAU, Jean-Jacques. Do Contrato Social. Tradução de Pietro Nassetti. São Paulo: Martin Claret, 2002.

SEN, Amartya. A ideia de Justiça. Denise Bottmann; Ricardo Doninelli Mendes (Trads). São Paulo: Companhia das Letras, 2011.

SILVA, José Afonso. Constitucionalismo Brasileiro: Evolução Institucional. São Paulo: Malheiros Editores, 2011.

SILVA, Virgílio Afonso da. Interpretação Constitucional e Sincretismo Metodológico. In . (org.). Interpretação Constitucional. São Paulo: Malheiros, 2007.

- O Judiciário e as políticas públicas. In PEREIRA DE SOUZA NETO; SARMENTO, Daniel (coords). Direitos Sociais: fundamentação, judicialização e direitos sociais em espécie. Rio de Janeiro: Lumen Juris, 2008. 
- Direitos Fundamentais: conteúdo essencial, restrições e eficácia. São Paulo: Malheiros, 2009.

STRECK, Lenio Luiz. Os modelos de juiz diante da democracia e da divisão de poderes no Estado democrático de direito. In TAVARES, André Ramos; LEITE, George Salomão; SARLET, Ingo Wolfgang (orgs). Estado Constitucional e organização do Poder. São Paulo: Saraiva, 2010.

. STRECK, Lenio Luiz in A nova perspectiva do Supremo Tribunal Federal sobre o controle difuso: mutação constitucional e limites da legitimidade da jurisdição constitucional, disponível em http://jus2.uol.com.br/doutrina/texto.asp?id=10253\&p=1, acesso em 03 de novembro de 2009.

TAVARES, André Ramos; LEITE, George Salomão; SARLET, Ingo Wolfgang (orgs). Estado Constitucional e organização do Poder. São Paulo: Saraiva, 2010.

TRIBE, Laurence H. The Invisible Constitution. New York: Oxford University Press, 2008.

VILHENA, Oscar. A Constituição como reserva de justiça. Revista Lua Nova, São Paulo: $n^{\circ}$ 42-97, p. 54, 2005.

WALDRON, Jeremy. A dignidade da legislação. Luís Carlos Borges (Trad). São Paulo: Martins Fontes, 2003.

ZAGREBELSKY, Gutavo. El Derecho Dúctil: Ley, derechos, justicia. Marina Gascón (Trad). Madrid: Editorial Trotta, 2011. ADEODATO, João Maurício (2009). A Retórica Constitucional. São Paulo: Saraiva. 
